Cochrane Database of Systematic Reviews

\title{
Anthelmintics for people with neurocysticercosis (Review)
}

Abba K, Ramaratnam S, Ranganathan LN

Abba K, Ramaratnam S, Ranganathan LN.

Anthelmintics for people with neurocysticercosis.

Cochrane Database of Systematic Reviews 2010, Issue 3. Art. No.: CD000215.

DOI: 10.1002/14651858.CD000215.pub4.

www.cochranelibrary.com 
TABLE OF CONTENTS

HEADER

ABSTRACT

PLAIN LANGUAGE SUMMARY

BACKGROUND

OBJECTIVES

METHODS

RESULTS

DISCUSSION

AUTHORS' CONCLUSIONS

ACKNOWLEDGEMENTS

\section{REFERENCES}

\section{CHARACTERISTICS OF STUDIES}

DATA AND ANALYSES

Analysis 1.1. Comparison 1 Albendazole vs placebo or no drug, Outcome 1 Recurrence of seizures at trial's final follow-up time.

Analysis 1.2. Comparison 1 Albendazole vs placebo or no drug, Outcome 2 No successful withdrawal of anticonvulsant drugs at follow up.

Analysis 1.3. Comparison 1 Albendazole vs placebo or no drug, Outcome 3 All-cause death.

Analysis 1.4. Comparison 1 Albendazole vs placebo or no drug, Outcome 4 Hospital admission, by follow-up period.

Analysis 1.5. Comparison 1 Albendazole vs placebo or no drug, Outcome 5 Symptoms not resolved after 3 months. ...............

Analysis 1.6. Comparison 1 Albendazole vs placebo or no drug, Outcome 6 Symptoms of encephalopathy (headache, vomiting, or altered sensorium), by period of follow up.

Analysis 1.7. Comparison 1 Albendazole vs placebo or no drug, Outcome 7 Persistence of lesions at trial's final follow-up time (up to 12 months).

Analysis 1.8. Comparison 1 Albendazole vs placebo or no drug, Outcome 8 Headache during treatment.

Analysis 1.9. Comparison 1 Albendazole vs placebo or no drug, Outcome 9 Headache during treatment - by corticosteroid use.

Analysis 1.10. Comparison 1 Albendazole vs placebo or no drug, Outcome 10 Dizziness during treatment.

Analysis 1.11. Comparison 1 Albendazole vs placebo or no drug, Outcome 11 Nausea, vomiting, or abdominal pain during treatment.

Analysis 1.12. Comparison 1 Albendazole vs placebo or no drug, Outcome 12 Seizures during treatment.

Analysis 2.1. Comparison 2 Praziquantel vs placebo or no drug, Outcome 1 Symptoms not resolved after 3 months.

Analysis 2.2. Comparison 2 Praziquantel vs placebo or no drug, Outcome 2 Persistence of lesions at follow up. ...................... Analysis 2.3. Comparison 2 Praziquantel vs placebo or no drug, Outcome 3 No reduction in number of lesions at 3 months. .... Analysis 2.4. Comparison 2 Praziquantel vs placebo or no drug, Outcome 4 Any adverse events during treatment. ..................

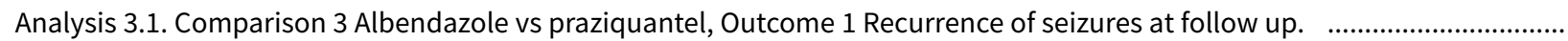
Analysis 3.2. Comparison 3 Albendazole vs praziquantel, Outcome 2 Symptoms not resolved after 3 months. ........................ Analysis 3.3. Comparison 3 Albendazole vs praziquantel, Outcome 3 Persistence of lesions at follow up. ................................ Analysis 3.4. Comparison 3 Albendazole vs praziquantel, Outcome 4 No reduction in number of lesions at 3 months. ............. Analysis 3.5. Comparison 3 Albendazole vs praziquantel, Outcome 5 Adverse events.

Analysis 4.1. Comparison 4 Albendazole combined with praziquantel vs albendazole alone, Outcome 1 Recurrence of seizures within 6 months.

Analysis 4.2. Comparison 4 Albendazole combined with praziquantel vs albendazole alone, Outcome 2 Persistence of lesions, by follow-up period.

Analysis 5.1. Comparison 5 Albendazole: longer vs shorter duration of treatment, Outcome 1 Symptoms not resolved after 3 months: 8 days vs more than 8 days.

Analysis 5.2. Comparison 5 Albendazole: longer vs shorter duration of treatment, Outcome 2 Persistence of lesions at longest length of follow up: 7 or 8 days vs. more than 7 to 8 days.

Analysis 5.3. Comparison 5 Albendazole: longer vs shorter duration of treatment, Outcome 3 No reduction in number of lesions at 3 months follow up, by length of treatment comparison.

Analysis 5.4. Comparison 5 Albendazole: longer vs shorter duration of treatment, Outcome 4 Adverse events.

2

3

3

3

Analysis 5.5. Comparison 5 Albendazole: longer vs shorter duration of treatment, Outcome 5 Persistence of lesions (viable lesions only): 3 days vs 8 days.

Analysis 6.1. Comparison 6 Albendazole: with corticosteroids vs without corticosteroids, Outcome 1 Recurrence of seizures between weeks 1 and 72 . 
Analysis 6.2. Comparison 6 Albendazole: with corticosteroids vs without corticosteroids, Outcome 2 Persistence of lesions at

6 months.

APPENDICES

WHAT'S NEW

HISTORY

CONTRIBUTIONS OF AUTHORS 
[Intervention Review]

\section{Anthelmintics for people with neurocysticercosis}

Katharine Abba ${ }^{1}$, Sridharan Ramaratnam², Lakshmi Narasimhan Ranganathan 3

1International Health Group, Liverpool School of Tropical Medicine, Liverpool, UK. 2Department of Neurology, Apollo Hospitals, Chennai, India. ${ }^{3}$ Department of Neurology, Kilpauk Medical College, Chennai, India

Contact address: Katharine Abba, International Health Group, Liverpool School of Tropical Medicine, Pembroke Place, Liverpool, Merseyside, L3 5QA, UK. K.abba@liverpool.ac.uk.

Editorial group: Cochrane Infectious Diseases Group

Publication status and date: Unchanged, published in Issue 5, 2019.

Citation: Abba K, Ramaratnam S, Ranganathan LN. Anthelmintics for people with neurocysticercosis. Cochrane Database of Systematic Reviews 2010, Issue 3. Art. No.: CD000215. DOI: 10.1002/14651858.CD000215.pub4.

Copyright @ 2019 The Cochrane Collaboration. Published by John Wiley \& Sons, Ltd.

\section{A B S T R A C T}

\section{Background}

Neurocysticercosis is an infection of the brain by the larval stage of the pork tapeworm. In endemic areas it is a common cause of epilepsy. Anthelmintics (albendazole or praziquantel) may be given to kill the parasites. However, there are potential adverse effects, and the parasites may eventually die without treatment.

\section{Objectives}

To assess the effectiveness and safety of anthelmintics for people with neurocysticercosis.

\section{Search methods}

In May 2009 we searched the Cochrane Infectious Diseases Group Specialized Register, CENTRAL (The Cochrane Library 2009, Issue 2), MEDLINE, EMBASE, LILACS, and the $m R C T$.

\section{Selection criteria}

Randomized controlled trials comparing anthelmintics with placebo, no anthelmintic, or other anthelmintic regimen for people with neurocysticercosis.

\section{Data collection and analysis}

Two authors independently selected trials, extracted data, and assessed each trial's risk of bias. We calculated risk ratios (RR) for dichotomous variables, with $95 \%$ confidence intervals $(\mathrm{Cl})$. We pooled data from trials with similar interventions and outcomes.

\section{Main results}

For viable lesions in children, there were no trials. For viable lesions in adults, no difference was detected for albendazole compared with no treatment for recurrence of seizures (116 participants, one trial); but fewer participants with albendazole had lesions at follow up (RR $0.56,95 \% \mathrm{Cl} 0.45$ to $0.70 ; 192$ participants, two trials).

For non-viable lesions in children, seizures recurrence was less common with albendazole compared with no treatment (RR $0.49,95 \% \mathrm{Cl}$ 0.32 to $0.75 ; 329$ participants, four trials). There was no difference detected in the persistence of lesions at follow up ( 570 participants, six trials). For non-viable lesions in adults, there were no trials.

In trials including viable, non-viable or mixed lesions (in both children and adults), headaches were more common with albendazole alone (RR 9.49, 95\% Cl 1.40 to 64.45; 106 participants, two trials), but no difference was detected in one trial giving albendazole with corticosteroids (116 participants, one trial). 


\section{Authors' conclusions}

In patients with viable lesions, evidence from trials of adults suggests albendazole may reduce the number of lesions. In trials of non-viable lesions, seizure recurrence was substantially lower with albendazole, which is counter-intuitive. It may be that steroids influence headache during treatment, but further research is needed to test this.

\section{March 2019}

Update pending

Authors currently updating

The update is due to be published in 2019.

\section{PLAIN LANGUAGE SUMMARY}

\section{Treatment for illness caused by tapeworm larvae in the brain}

If people eat eggs from the pork tapeworm (Taenia solium), these eggs can move from the gut and then lodge in different tissues of the body forming cysts. When these cysts form in the brain, this is called neurocysticercosis. Some people may have no symptoms if this happens, but others may suffer from seizures, headaches, or more rarely from confusion, loss of balance or brain swelling. More rarely still, someone may die.

The condition is mainly found where people live in close contact with pigs and where the sanitation is poor. It affects around 50 million people worldwide, and in some areas is the leading cause of adult-onset epilepsy.

The number, size and location of the cysts help to guide treatment of neurocysticercosis, as do the patient's symptoms; for example, giving anticonvulsants to someone with seizures. Two drugs, praziquantel and albendazole, can be used specifically in neurocysticercosis to help kill the parasite; these drugs are known as anthelmintics. Some cysts, called non-viable lesions are generally in the process of degenerating and resolving spontaneously; many experts recommend not treating this type of cyst. However, treating viable lesions (ie those lesions that may or may not resolve spontaneously) with these drugs may help kill the parasite, although treatment remains controversial due to the potential side effects and the fact the parasite may die without treatment.

In this review of 21 relevant randomized controlled trials, most studies examined the effects of albendazole. In patients with viable lesions, there is only evidence available for adult patients; this suggests that albendazole may reduce the number of lesions. In patients with nonviable lesions, there is only evidence available for children; this suggests that seizure recurrence was lower with albendazole, which goes against the opinions of some experts. There is insufficient evidence available to assess praziquantel. 


\section{B A C K G R O U N D}

Neurocysticercosis is an infection of the central nervous system by the larval stage of the pork tapewormTaenia solium. If eggs (cysticerci) from the faeces of humans infected with the intestinal parasites are ingested, they can migrate from the gut to lodge in various tissues of the body, where they form cysts (cysticercosis). This review is confined to treating neurocysticercosis, where the cysts lodge in the brain.

The cysts naturally evolve, over a period of years, through stages beginning with viable larvae and ending with the death of the parasite and resorption or calcification of the cyst. Individuals may have one or more cysticerci in the brain. The following types of neurocysticercosis have been recognized, depending on where the cysts are lodged: parenchymal; intraventricular; racemose type found in the basal cisterns; and spinal. Symptoms may or may not occur, depending on the number, location, and stage of the cysts, as well as the infected person's immune response. Seizures are the most common symptom, present in most of the presenting cases, followed by headaches. Rarely, it causes confusion, lack of attention to people and surroundings, difficulty with balance, paralysis, swelling of the brain, and very rarely, death. Symptoms may be associated with the host's immune response or due to calcifications left once the cysts have been eliminated (Leite 2000).

The condition is found where people live in close contact with pigs and where sanitation is poor. It is common in much of South and Central America, China, the Indian subcontinent and South-East Asia, and sub-Saharan Africa. It affects around 50 million people worldwide (Kossoff 2005), with men and women equally affected, and has a peak of incidence at the ages of 30 to 40 years (Burneo 2005). In endemic areas, it is the leading cause of adult-onset epilepsy and an important cause of seizures in children (Roman 2000). It has also been estimated to cause at least 50,000 deaths worldwide each year (Roman 2000). It is therefore a significant public health problem, with significant associated costs in health care and lost productivity.

The cysts in the brain can be visualized using CT or MRI scanning. Over the course of the infection, radiological images change from 'non-enhancing' (after intravenous injection of a radiographic contrast), indicating a viable cyst with little host immune response, to 'ring-enhancing' indicating a degenerating cyst with surrounding immune response, to calcification or total resolution (DeGiorgio 2004). Cysts may be located in the parenchyma (brain tissue) or within structures and spaces around the brain (extraparenchymal cysts). Infection burden varies widely; a recently published guideline classified infection burdens from mild (one to five cysts) to moderate (five to 99 cysts) to heavy (more than 100 cysts) (Garcia 2002).

Treatment options depend on the number, size, and location of the cysts, and on the symptoms. Initial symptomatic treatment includes anticonvulsant drugs for seizures and analgesics for headache. Some extraparenchymal cysts are treated with surgery, either to remove the cyst or to relieve intracranial pressure. Where serious inflammation of the brain is present (usually associated with degeneration of the cysts), corticosteroids may be prescribed.

Cysts may degenerate and resolve spontaneously. For this reason, specific anthelmintics are usually considered for people with viable cysts, as the treatment may help kill the parasites. When lesions are non-viable, many experts do not recommend these drugs.

There are two anthelmintics used in neurocysticercosis: praziquantel, available since 1979 , and albendazole, available since 1987. If anthelmintics are used, corticosteroids are often prescribed with them to prevent inflammation of the brain caused by the host immune response to the destroyed parasites.

Treatment with anthelmintics remains controversial, due to potential adverse events and the natural history of the parasite, which may eventually die without treatment. The original version of this Cochrane Review found no evidence that the potential benefits of treatment outweigh the potential harms (Salinas 1999). This review was undertaken as a substantive update of the original Cochrane Review to take trials published since 1999 into account. We have stratified patients by age (children and adult) and by whether patients have predominantly viable or non-viable cysts, given the natural history and assumptions about when anthelmintics may or may not be effective.

\section{O B JECTIVES}

To assess the effects of anthelmintics for people with neurocysticercosis.

\section{METHODS}

\section{Criteria for considering studies for this review}

\section{Types of studies}

Randomized controlled trials.

\section{Types of participants}

People with symptomatic or asymptomatic neurocysticercosis defined by viable or non-viable lesions in the brain, identified as 'non-enhancing' or 'ring-enhancing' on medical imaging..

\section{Types of interventions}

\section{Intervention}

- Anthelmintics plus usual treatment.

- Anthelmintics plus corticosteroids plus usual treatment.

\section{Control}

- Usual treatment only.

- Corticosteroids plus usual treatment.

- Another anthelmintic plus usual treatment.

- Another dose or duration of anthelmintic, plus usual treatment.

We included trials irrespective of the type of anthelmintic used, or the dosage and duration of treatment.

\section{Types of outcome measures}

\section{Primary}

- Free of seizures for one year after treatment.

- Recurrence of seizures at follow-up.

- Number of seizures during follow-up period.

- Seizure free at follow-up following withdrawal of anticonvulsant drugs. 


\section{Secondary}

Health status indicators

- All-cause death.

- Hospital admission for any cause.

- Any neurological symptoms or signs (includes headache, paralysis, visual disturbance).

- Need for surgery.

- Resumption of normal activities at follow up; or time to resumption of normal activities.

- Resolution of symptoms.

Radiological changes at follow up

- Persistence of lesions.

- Reduction in number of lesions.

- Reduction in ventricular size.

Adverse events

- Any adverse events.

- Adverse event requiring withdrawal of anthelmintic drugs.

\section{Search methods for identification of studies}

We attempted to identify all relevant trials regardless of language or publication status (published or unpublished, in press, or in progress)

\section{Databases}

We searched the following databases using the search terms and strategy described in Appendix 1: the Cochrane Infectious Diseases Group Specialized Register (May 2009); the Cochrane Central Register of Controlled Trials (CENTRAL), published in The Cochrane Library (2009, Issue 2); MEDLINE (1966 to May 2009); EMBASE (1988 to May 2009); and LILACS (1982 to May 2009). We also searched the metaRegister of Controlled Trials (mRCT) using the term 'neurocysticercosis' May 2009).

\section{Reference lists}

We also checked the reference lists of all trials and review articles identified by the above method.

\section{Data collection and analysis}

\section{Selection of studies}

Two authors (KA and LR) independently screened all citations and abstracts, using an eligibility form to apply the selection criteria to identify relevant studies. Where there was uncertainty over the eligibility of a particular study, we obtained the full-text article. We resolved any differences in opinion by discussion or, where necessary, by discussion with the third author (SR). We excluded studies that did not meet the criteria, and documented the reasons for exclusion in the table 'Characteristics of excluded studies'.

\section{Data extraction and management}

One author $(\mathrm{KA})$ extracted data using a tailored data extraction form, and a second author (LR) checked this extracted data, after which any disagreements were resolved by discussion. We summarized data on study design, participant characteristics, interventions, and outcomes and entered these into Review Manager 5.

\section{Assessment of risk of bias in included studies}

Two review authors independently assessed the risk of bias of the included trials using a pro forma. In case of disagreement, we planned to consult a third person. We categorized the generation of the allocation sequence and allocation concealment as adequate, unclear, or inadequate as in Jüni 2001. We assessed whether the participants, care providers and investigators were blinded to which participants received which drug regimen. For all outcomes, we assessed that incomplete outcome data had been adequately addressed if $85 \%$ or more of the participants were included in the analysis, or if less than $85 \%$ were included but adequate steps were taken to ensure or demonstrate that this did not bias the results. We also examined the trial reports for any evidence of selective reporting of outcomes or any other issues that may bias the results. We reported the results of the assessment in a table.

\section{Assessment of reporting biases}

We planned to assess the probability of publication bias by examining the funnel plot for asymmetry, using one of the primary outcomes of seizure recurrence with the largest number of contributing trials. However, there were not enough trials reporting on the same primary outcomes to present a meaningful analysis.

\section{Data synthesis}

We analysed the data using Review Manager 5. We calculated risk ratio (RR) for dichotomous data and mean difference (MD) for continuous data. We measured precision using 95\% confidence intervals $(\mathrm{Cl})$. Where more than one trial included similar participants and interventions, without significant clinical or methodological diversity or statistical heterogeneity, we undertook a meta-analysis using a fixed-effect model. Highly skewed data (where the standard deviation was greater than the mean) were presented in the text. Analyses were based on the number of available participants at each stage of follow up; there was no adjustment for loss to follow up.

We stratified the results by treatment comparison and type of lesion; viable (non-enhancing) or non-viable (enhancing).

\section{Subgroup analysis and investigation of heterogeneity}

We assessed heterogeneity between trials by examining the forest plot for overlapping confidence intervals, and using the $1^{2}$ statistic for heterogeneity. We investigated potential sources of heterogeneity by performing subgroup analyses by co-medications or treatments used and, where possible, length of follow up. We planned also to investigate potential sources of heterogeneity by performing subgroup analyses for participant age (adults or children), and number of lesions, but there were insufficient trials to enable this.

\section{Sensitivity analysis}

Where sufficient trial data were available, we undertook sensitivity analyses by excluding trials without adequate reported allocation concealment. 


\section{RES U L T S}

\section{Description of studies}

\section{Eligibility}

We included 21 completed trials. (see 'Characteristics of included studies') We excluded nine studies (see reasons in 'Characteristics of excluded studies'). Three studies are classified as awaiting assessment because it was unclear from the reports whether or not they were randomized. We have emailed and written to the authors for more detailed information about the methods.The search also identified one ongoing trial that met the inclusion criteria (see 'Characteristics of ongoing studies').

In detail, the search strategy identified 48 potentially relevant reports of completed studies; of these, 35 initially seemed relevant, and we obtained the full texts. One was in Portuguese (Antoniuk 1991), the others in English. We obtained the help of a Portuguese reader to assess the relevant report for inclusion. Two reports were unclear as to whether the groups were randomly allocated: we attempted to contact the trial authors for clarification but were unsuccessful; these trials are reported as 'awaiting classification'. Following inspection of the reference lists of the included reports, we identified a further two relevant trials for inclusion (Padma 1994; Sotelo 1990), and another report that initially seemed relevant but did not meet the inclusion criteria (Medina 1993).

\section{Trial location and setting}

The included trials were conducted in Ecuador (five trials), Mexico (three trials), Peru (two trials), and India (11 trials). All were carried out within hospital settings, with treatment provided on an inpatient basis.

\section{Trial participants}

\section{Viable lesions}

Six trials included 322 participants (151 males, 148 females, 23 sex not reported) with viable lesions, or a combination of viable and non-viable lesions. Among these, four trials were conducted in adults (274 participants) and two trials included both children and adults (48 participants). Two trials did not specify the number of lesions, one trial included participants with up to three lesions, one trial with up to six lesions, and two trials with less than 20 lesions. All lesions in these studies were located in the parenchyma of the brain. None of the trials mentioned including or excluding people who were HIV positive.

\section{Non-viable lesions}

Nine trials included 941 participants (44 males, 321 females and 176 sex not reported) with non-viable lesions only. Among these, seven trials were conducted in children (763 participants) and two included both adults and children (178 participants). Six trials included only participants with single lesions, one trial included those with up to two lesions, one included those with up to three lesions, and one did not specify number of lesions. All lesions in these studies were located in the parenchyma of the brain. None of the trials mentioned including or excluding people who were HIV positive.

\section{Mixed viable and non-viable lesions}

Seven trials included 676 participants (392 male, 280 female and four sex not reported) whose type of lesion was unspecified. Among these five trials were conducted in adults (469 participants) and two trials included both adults and children (207 participants). Five trials did not specify the number of lesions in each participant, while two trials included only participants with more than one lesion. Five trials included parenchymal lesions only, while one included only subarachnoid and intraventricular lesions and another included parenchymal, subarachnoid and intraventricular lesions. None of the trials mentioned including or excluding people who were HIV positive.

\section{Interventions}

\section{Viable lesions}

The comparisons included in the trials included:

- Albendazole versus placebo or no drug (four trials) (Alarcon 1989; Garcia 1997; Alarcon 2001; Garcia 2004).

- Albendazole versus praziquantel (two trials) (Sotelo 1990; Del Brutto 1999).

- Albendazole: longer versus shorter duration of treatment (four trials) (Alarcon 1989; Sotelo 1990; Garcia 1997; Alarcon 2001).

- Praziquantel: same daily dose given for different durations (one trial) (Sotelo 1990).

In addition to anthelmintics, three trials also used corticosteroids; two in all the comparison groups (Garcia 1997; Del Brutto 1999) and one in the treatment groups only (Garcia 2004). Most trials reported providing anticonvulsant drugs for all patients who were having seizures, whichever treatment group they were randomized to.

\section{Non-viable lesions}

The comparisons included in the trials included:

- Albendazole versus placebo or no drug (six trials) (Padma 1994; Baranwal 1998; Singhi 2000; Gogia 2003; Kalra 2003; De Souza 2009).

- Albendazole plus praziquantel versus albendazole plus placebo (one trial) (Kaur 2009).

- Albendazole: longer versus shorter duration of treatment (one trial) (Singhi 2003).

- Albendazole with corticosteroids versus albendazole without corticosteroids (one trial) (Singhi 2004).

In addition to anthelmintics, five trials also used corticosteroids; three in the treatment and control groups (Baranwal 1998; Gogia 2003; Kaur 2009), one in the treatment groups only (Kalra 2003), and one in the control group and one of two intervention groups (Singhi 2004). Most trials reported providing anticonvulsant drugs for all patients who were having seizures, whichever treatment group they were randomized to.

\section{Mixed viable and non-viable lesions}

The comparisons included in the trials included:

- Albendazole versus placebo or no drug (five trials) (Sotelo 1988; Padma 1995; Garcia 1997; Das 2007; Carpio 2008).

- Praziquantel versus placebo or no drug (one trial) (Sotelo 1988). 
- Albendazole versus praziquantel (one trial) (Sotelo 1988).

- Albendazole: longer versus shorter duration of treatment (two trials) (Cruz 1995; Garcia 1997).

- Albendazole: different doses given over a one-day period (one trial) (Gongora-Rivera 2006).

In addition to anthelmintics, five trials also used corticosteroids; three in the treatment and control groups (Garcia 1997; GongoraRivera 2006; Carpio 2008), one in the treatment groups only (Das 2007), and one in the control group only (Sotelo 1988). Most trials reported providing anticonvulsant drugs for all patients who were having seizures, whichever treatment group they were randomized to.

One ongoing study is comparing albendazole plus corticosteroid with placebo (Gilman 2007).

\section{Outcomes}

\section{Viable lesions}

Three of the included trials reported outcomes relating to the presence or severity of seizures at follow up. A further trial reported on the presence or severity of any symptoms. All the trials reported on radiologically visible changes to the numbers or sizes of lesions.

\section{Non-viable lesions}

Seven of the included trials reported outcomes relating to the presence or severity of seizures at follow up. All the trials reported on radiologically visible changes to the numbers or sizes of lesions.

\section{Mixed viable and non-viable lesions}

Three of the included trials reported outcomes relating to the presence or severity of seizures at follow up. A further two reported on the presence or severity of any symptoms. All the included trials reported on radiologically visible changes to the numbers or sizes of lesions.

There were no trials reporting on freedom from seizures for one year, resumption of normal activities, reduction in ventricular size, or adverse events requiring withdrawal of anthelmintic drugs.

\section{Risk of bias in included studies}

Details of the methods used in each trial are available in the table 'Characteristics of included studies'.

\section{Generation of allocation sequence}

\section{Viable lesions}

Two trials described an adequate method of generating a truly random allocation sequence. Four trials did not report how they generated group allocation sequences (assessed as 'unclear'), but all were described as 'randomized'.

\section{Non-viable lesions}

Seven trials described an adequate method of generating a truly random allocation sequence. Two trials did not report how they generated group allocation sequences (assessed as 'unclear'), but all were described as 'randomized'.

\section{Mixed viable and non-viable lesions}

Three trials described an adequate method of generating a truly random allocation sequence. Four trials did not report how they generated group allocation sequences (assessed as 'unclear'), but all were described as 'randomized'.

\section{Allocation concealment}

\section{Viable lesions}

One trial reported an adequate method of ensuring allocation concealment. Five trials did not report enough information to allow allocation concealment to be assessed.

\section{Non-viable lesions}

Four trials reported an adequate method of ensuring allocation concealment. Five trials did not report enough information to allow allocation concealment to be assessed.

\section{Mixed viable and non-viable lesions}

Two trials reported an adequate method of ensuring allocation concealment. Five trials did not report enough information to allow allocation concealment to be assessed.

\section{Blinding}

\section{Viable lesions}

Three trials reported blinding of participants, personnel and outcomes assessors for all main outcomes. It was unclear whether blinding was done for the other three trials.

\section{Non-viable lesions}

Five trials reported blinding of participants, personnel and outcomes assessors for all main outcomes. It was unclear whether blinding was done for three trials. One trial did not use blinding.

\section{Mixed viable and non-viable lesions}

Four trials reported blinding of participants, personnel and outcomes assessors for all main outcomes. It was unclear whether blinding was done for three trials.

\section{Addressing incomplete outcomes data \\ Viable lesions}

Five trials either included $85 \%$ or over of the participants in the analysis, or included fewer than $85 \%$ of participants, but showed that participants who were not included were similar to those included. One trial did not meet this criteria.

\section{Non-viable lesions}

Six trials either included $85 \%$ or over of the participants in the analysis, or included fewer than $85 \%$ of participants, but showed that participants who were not included were similar to those included. Two trials did not meet this criteria, while in one trial this was unclear.

\section{Mixed viable and non-viable lesions}

Seven trials either included $85 \%$ or over of the participants in the analysis, or included fewer than $85 \%$ of participants, but showed that participants who were not included were similar to those included. 


\section{Effects of interventions}

\section{Albendazole versus placebo or no drug}

\subsection{Recurrence of seizures}

\section{Viable lesions}

One small trial with adequate allocation concealment, including adults only, reported on recurrence of seizures by end of follow up, showing no significant effect of albendazole treatment (116 participants, Analysis 1.1).

\section{Non-viable lesions}

Four trials reported data on this outcome that could be included within meta-analysis. All four non-viable lesions included only children with one or two lesions. Albendazole showed a significant benefit (relative risk 0.49 , 95\% confidence interval (Cl) 0.32 to $0.75 ; 329$ participants, Analysis 1.1). One of the included trials (Gogia 2003) excluded seizures occurring during the first week of the trial, but is included in the analysis because its exclusion did not change the finding. In a sensitivity analysis, including only the three trials with adequate allocation concealment, this significant benefit remained (RR $0.53,95 \% \mathrm{Cl} 0.31$ to $0.88 ; 125$ participants). One additional trial (103 participants, De Souza 2009) reported no significant differences in seizure recurrence between the albendazole and no anthelmintic groups, but did not present data.

\section{Mixed viable and non-viable lesions}

One trial, with unclear allocation concealment, reported on this outcome, showing a harmful effect of albendazole (RR 2.36, 95\% $\mathrm{Cl} 1.43$ to 3.91; 298 participants, one trial, Analysis 1.1). Another trial, with adequate allocation concealment, presented data on the number of participants who remained free of seizures at 12 months, using Kaplan-Meier survival analysis, and found no significant difference between the albendazole and placebo groups (Carpio 2008).

One trial reported on the successful withdrawal of anticonvulsants during a two-year follow-up period (Garcia 2004); there was no significant difference between the albendazole and control groups (116 participants, Analysis 1.2).

\subsection{Deaths and hospital admissions}

\section{Viable lesions}

No trials reported on these outcomes.

\section{Non-viable lesions}

No trials reported on these outcomes.

\section{Mixed viable and non-viable lesions}

Two trials reported a total of nine deaths (Analysis 1.3). There was no significant difference between albendazole and treatment groups in the number of deaths overall (470 participants, two trials).

One trial (Das 2007) reported on hospital re-admissions after treatment (Analysis 1.4). Participants treated with albendazole had a higher risk of hospital admission during the periods up to three months (RR 2.53, 95\% Cl 1.54 to 4.17; 298 participants), three to six months (RR $5.07,95 \% \mathrm{Cl} 2.17$ to 11.82 ), and six to 12 months (RR $4.56,95 \% \mathrm{Cl} 1.58$ to 13.16 ). There was no significant difference between the albendazole and control groups during periods one to two years, two to three years, or three to four years.

\subsection{Resolution of symptoms}

\section{Viable lesions}

In one very small trial, fewer participants receiving albendazole had no resolution of symptoms ('symptom' not defined by the trial authors) at three months than in the control group (RR 0.25, 95\% Cl 0.07 to $0.93 ; 15$ participants, Analysis 1.5 ).

\section{Non-viable lesions}

No trials in non-viable lesions reported on these outcomes.

\section{Mixed viable and non-viable lesions}

One trial reported on presence of symptoms of encephalopathy (headache, vomiting, and altered sensorium) during different time periods. The albendazole group had a higher risk of symptoms during the period up to three months (RR $3.04,95 \% \mathrm{Cl} 1.77$ to 5.21; 298 participants, Analysis 1.6), but there was no significant difference between the groups during other periods of time up to four years.

\subsection{Persistence of radiological lesions}

For the purposes of this review, persistence of lesions relates to the presence of cysts or lesions in any form, including calcified or nodular lesions.

\section{Viable lesions}

In trials including only adults with viable lesions, participants treated with albendazole compared with no anthelmintic had a lower risk of persistence of lesions at follow up (RR $0.56,95 \% \mathrm{Cl} 0.45$ to $0.70 ; 114$ participants, two trials, Analysis 1.7)

\section{Non-viable lesions}

In trials including mainly children with non-viable lesions (one trial also included adults), there was no difference between the albendazole and no anthelmintic groups in persistence of lesions at follow up (570 participants, six trials, Analysis 1.7). A trial in adults and children (103 participants, De Souza 2009) reported no significant difference in cyst disappearance between the albendazole and no anthelmintic groups but did not present the data.

\section{Mixed viable and non-viable lesions}

In one trial including adults with both viable and non-viable lesions, there was no difference between the albendazole and no anthelmintic groups in persistence of lesions at follow up (298 participants, Analysis 1.7).

\subsection{Adverse events during treatment}

\section{All types of lesion}

There were no significant differences detected between the albendazole and no anthelmintic groups in the numbers of participants with headache during treatment in trials with viable lesions only (139 participants, two trials, Analysis 1.8), non-viable lesions only (83 participants, one trial, Analysis 1.8), or mixed viable and non-viable lesions (170 participants, one trial, Analysis 1.8). Overall, headache during treatment was more frequent in participants treated with albendazole than those not receiving 
anthelmintics (RR 1.37, 95\% Cl 1.08 to $1.73 ; 392$ participants, four trials, Analysis 1.8).

In a subgroup analysis by use of corticosteroids, there was a significant difference between the albendazole and no anthelmintic groups in headache during treatment when the albendazole group did not receive corticosteroids (RR 9.49, 95\% $\mathrm{Cl} 1.4$ to 64.45 ; 106 participants, two trials, Analysis 1.9), but no significant difference in trials where participants in the albendazole group received corticosteroids.

In analyses not separating trials by types of lesion, there was a greater risk of adverse events with albendazole for dizziness during treatment (Analysis 1.10), and nausea, vomiting and abdominal pain (Analysis 1.11). There was no significant difference between the albendazole and no anthelmintic groups in occurrence of seizures during treatment (455 participants, five trials, Analysis 1.12)

\section{Praziquantel versus placebo or no drug}

One small trial made this comparison (15 participants, Sotelo 1988). The trial included participants with viable lesions, non-viable lesions, or both. It did not report on recurrence of seizures, deaths or hospital admissions.

\subsection{Resolution of symptoms}

There was no significant difference between praziquantel and no anthelmintic for continuing presence of symptoms at three months (15 participants, Analysis 2.1)

\subsection{Radiological changes at follow up}

There was a significant difference between praziquantel and no anthelmintic in persistence of lesions at follow up (RR 0.15, 95\% $\mathrm{Cl} 0.03$ to $0.67,15$ participants, Analysis 2.2). More participants treated with praziquantel than no anthelmintic had a reduction in the number of lesions at three months follow up (RR $0.15,95 \% \mathrm{CI}$ 0.03 to $0.67 ; 15$ participants, Analysis 2.3 ).

\subsection{Adverse events during treatment}

More participants treated with praziquantel compared with no anthelmintic reported any adverse event during treatment, although the difference was not significant (15 participants, Analysis 2.4).

\section{Albendazole versus praziquantel}

Three trials reported on this comparison (Sotelo 1988; Sotelo 1990; Del Brutto 1999). All three trials included only participants with viable lesions.

\subsection{Recurrence of seizures}

In one small trial, there was no significant difference in the risk of recurrence of seizures with albendazole treatment compared with praziquantel (19 participants, Analysis 3.1).

\subsection{Resolution of symptoms}

Fewer participants treated with albendazole compared with praziquantel still had symptoms of neurocysticercosis (types of symptoms not specified in the reports) three months after treatment (RR $0.58,95 \% \mathrm{Cl} 0.36$ to $0.92 ; 121$ participants, two trials, Analysis 3.2).

\subsection{Persistence of radiological lesions at follow up}

There was a significant benefit of albendazole over praziquantel in the number of participants with persistence of lesions at follow up at three to six months (RR $0.64,95 \% \mathrm{Cl} 0.45$ to $0.91 ; 154$ participants, three trials, Analysis 3.3).

Significantly fewer participants in the albendazole group had more lesions, or the same number of lesions, at follow up than before treatment (RR $0.41,95 \% \mathrm{Cl} 0.19$ to $0.92 ; 149$ participants, three trials, Analysis 3.4).

\subsection{Adverse events during treatment}

There were no significant differences between albendazole and praziquantel in the number of adverse events during treatment (Analysis 3.5).

\section{Albendazole combined with praziquantel versus albendazole alone}

One trial, including only children with single non-viable lesions, reported on this comparison.

\subsection{Recurrence of seizures}

There was no significant difference between the groups in recurrence of seizures at six months (112 participants, Analysis 4.1).

\subsection{Persistence of radiological lesions}

Albendazole combined with praziquantel was associated with lower risk of persistence of lesions at six months compared with albendazole alone (RR $0.59,95 \% \mathrm{Cl} 0.35$ to $0.99 ; 103$ participants, Analysis 4.2). At one month and three months there was no significant difference between the groups, but there was a trend towards benefit of albendazole combined with praziquantel.

\subsection{Adverse events}

Three children receiving albendazole combined with praziquantel and two children receiving albendazole alone developed headache on day three to four of treatment lasting for one or two days. None reported any gastrointestinal symptoms. There were no signs of raised intracranial pressure and none of the children required withdrawal of drugs.

\section{Albendazole: longer versus shorter duration of treatment}

Six trials reported on this comparison (Alarcon 1989; Sotelo 1990; Cruz 1995; Garcia 1997; Alarcon 2001; Singhi 2003). This included three trials where participants had only viable lesions (Alarcon 1989; Sotelo 1990; Alarcon 2001), one trial including non-viable lesions only (Singhi 2003), and two trials where participants had viable, non-viable or both types of lesion (Cruz 1995; Garcia 1997).

\subsection{Recurrence of seizures and resolution of symptoms}

\section{Viable lesions}

One trial (Alarcon 2001) assessed the mean number of seizures at 12 months after treatment. The results were highly skewed, but there was no apparent difference between groups treated for eight days and groups treated for three days (54 participants, $0.3(+/-0.5)$ compared with $0.5(+/-1.0))$.

One trial assessed the resolution of symptoms (not clearly defined in the trial report) three months after treatment. There was no 
difference between groups treated for up to eight days and more than eight days in the number of participants whose symptoms had not resolved (49 participants, Analysis 5.1).

\section{Non-viable lesions}

No trials made this comparison.

\section{Mixed viable and non-viable lesions}

One trial assessed the resolution of symptoms (not clearly defined in the trial report) three months after treatment. There was no difference between groups treated for up to eight days and more than eight days in the number of participants whose symptoms had not resolved (53 participants, Analysis 5.1).

\subsection{Persistence of radiological lesions}

\section{Viable lesions}

There was no significant difference in persistence of lesions at final follow up between groups receiving albendazole for seven or eight days and longer than seven or eight days (103 participants, two trials, Analysis 5.2). There was also no significant difference between groups given albendazole for three days or eight days (54 participants, one trial).

\section{Non-viable lesions}

There was no significant difference in persistence of lesions at final follow up between groups receiving albendazole for seven or eight days and longer than seven or eight days (159 participants, two trials, Analysis 5.2).

\section{Mixed viable and non-viable lesions}

There was no significant difference in persistence of lesions at final follow up between groups receiving albendazole for seven or eight days and longer than seven or eight days (79 participants, two trials, Analysis 5.2).

\subsection{Adverse events}

\section{All types of lesion}

In analyses not separating trials by type of lesion, participants receiving shorter treatment durations reported fewer cases of nausea or other gastrointestinal symptoms than those receiving longer treatments (RR $0.54,95 \% \mathrm{Cl} 0.30$ to $0.97 ; 244$ participants, four trials, Analysis 5.4).

\section{Albendazole: with corticosteroids versus without corticosteroids}

One trial, including participants with non-viable lesions only (Singhi 2004), made this comparison.

\subsection{Recurrence of seizures}

There was no significant difference between in recurrence of seizures during weeks one to 72 after treatment ( 72 participants, Analysis 6.1).

\subsection{Radiological resolution of lesions}

There was no significant difference between albendazole alone and albendazole with corticosteroids in the persistence of lesions at six months after treatment (72 participants, Analysis 6.2).

\subsection{Adverse events}

This trial did not report on adverse events.

\section{DISCUSSION}

\section{Summary of main results}

The results of trials comparing anthelmintic treatment with no anthelmintic are mixed and therefore difficult to interpret. Most trials assessed albendazole, which has largely taken over from praziquantel. We found only one small trial comparing praziquantel with no active treatment from which we could not come to any meaningful conclusions on its efficacy. Reduction in seizures with albendazole did not appear to correlate with radiological clearance of lesions. Findings for the three major outcomes categories of this review are described below.

\section{Seizure recurrence}

For seizure recurrence, most trials tended towards a benefit of albendazole, and this benefit was significant in the case of children with a single, non-viable lesion. This finding runs counter to most expert opinion which is of a view that treatment is unlikely to be beneficial for cases with non-viable lesions only. There was no significant benefit shown for people with viable lesions only, which seems counter-intuitive, but only one small trial reported on this outcome, hence a larger study is needed to ascertain the efficacy of albendazole in this group. One trial, including participants with both viable and non-viable lesions (Das 2007), showed a harmful effect of albendazole. This trial, which combined albendazole with steroids, also showed increased encephalopathy and admission to hospital with albendazole, and two deaths from encephalopathy.

\section{Radiological clearance of lesions}

For radiological clearance of lesions during the first 12 months, trials including people with viable lesions only showed a significant benefit of albendazole, while trials including only people with nonviable lesions, or a mixture of viable and non-viable lesions, showed no significant effect of albendazole. The majority of trials on viable lesions involved adults only, while those on non-viable lesions involved only children; the observed differences between trial results may also have been affected by the ages of the participants.

Our analysis showed no significant effect of duration of treatment on persistence of lesions at follow up. Assuming that presence of symptoms is associated with presence of lesions (Murthy 2006), these results suggest that a shorter duration of treatment is as effective as a longer course. Shorter courses were also associated with fewer cases of nausea or other gastrointestinal symptoms during treatment. One trial assessed albendazole in combination with praziquantel compared with albendazole alone; the findings suggested that the combination of two anthelmintics was better in the short term.

\section{Adverse events}

Participants treated with either albendazole or praziquantel experienced significantly more adverse events during treatment than those receiving no active treatment. Albendazole was associated with headache, dizziness, and nausea, vomiting and abdominal pain. There is some indirect (weak) evidence that corticosteroids used in conjunction with albendazole may protect against headache during treatment, as in trials using 
corticosteroids there was no significant difference between albendazole and no active treatment in this outcome.

\section{Overall completeness and applicability of evidence}

We identified 21 relevant published trials. Most were published since the last update of this Cochrane Review (Salinas 1999). We also identified one relevant ongoing trial. All the trials were small; the largest enrolled 300 participants and the smallest enrolled 18. All trials, published and ongoing, were based in Central and South America and South-East Asia; there were no trials from Africa or China, where the disease is also endemic.

The trial participants varied, including children and adults and people with different numbers and types of lesions, although trials in children tended to include only non-viable lesions, while trials in adults mostly included only viable lesions. Together the trials included very few people with large numbers of lesions, or with lesions other than parenchymal cysts or lesions.

Treatment comparisons of the included trials were wide ranging, enabling analysis by type of drug (albendazole or praziquantel) and duration of treatment. We were also able to indirectly compare the frequencies of adverse events during treatment when anthelmintics were administered with or without corticosteroids.

Two comparisons reported by the included trials are not presented in the analysis because their comparisons did not fit into its structure. Gongora-Rivera 2006 compared only different doses of albendazole given for just one day; this was not presented as we had no other trials using albendazole for just one day, and hence no evidence that it was better than placebo. Sotelo 1990 compared praziquantel given for different durations; this comparison was not presented because we found no evidence that praziquantel was effective in treating neurocysticercosis.

Just over half of the included trials reported on the presence or severity of seizures, which are probably the most important outcomes to most patients. Three other trials reported on symptom severity or presence of symptoms, of which seizures would be the most common, and one trial reported separately on symptoms other than seizures. All the trials assessed and reported on the radiological presence or changes in the neurocysticerci, which may not be directly correlated with the presence or severity of seizures or other symptoms. Radiological outcomes are easy to assess, specific to neurocysticercosis, and perhaps clinically useful, as there is evidence that anti-epileptic drugs can usually be withdrawn following radiological clearance of lesions, and this may be a criteria for withdrawing anti-epileptic drugs in some patients and practices (Murthy 2006). However, in this review, children with a single non-viable lesion, and treated with albendazole compared with no anthelmintic, had a lowered risk of recurrence of seizures despite no difference in the radiological persistence of lesions.

\section{Quality of the evidence}

The risk of bias varied between trials, with the trials published most recently tending to be assessed as better for all indicators. Six trials reported an adequate method of allocation concealment; one trial including viable lesions only, four including non-viable lesions only, and two including both viable and non-viable lesions.

\section{Potential biases in the review process}

All of the included trials were small. In addition, unexplained heterogeneity was introduced by one relatively large, but poorly reported trial (Das 2007) with results mostly running in the opposite direction to those reported in other trials.

\section{Agreements and disagreement with other studies and reviews}

Our results slightly vary from other recent meta-analyses assessing albendazole compared with placebo or usual care, but the conclusions reached are similar.

A meta-analysis in children (four trials, 400 participants) with neurocysticercosis revealed a higher remission of seizures in those treated with albendazole compared to controls (RR 1.26, 95\% Cl 1.09 to 1.46). This agrees with our findings in children with nonviable lesions only. The authors also reviewed 10 observational studies and found conflicting results (Mazumdar 2007).

Del Brutto and colleagues (Del Brutto 2006) reported a metaanalysis of 11 randomized trials of patients with neurocysticercosis located in or adjacent to the cerebral parenchyma. Anthelmintic drug therapy was associated with complete resolution of viable lesions (44\% versus $19 \% ; P=0.025$ ) at follow up. Trials on nonviable lesions showed a trend toward lesion resolution favouring anthelmintic drugs $(72 \%$ versus $63 \%$; $P=0.38$ ), but this was not significant. In patients with non-viable lesions, risk for seizure recurrence was lower after anthelmintic treatment (14\% versus $37 \% ; \mathrm{P}<0.001)$. The single trial evaluating the frequency of seizures in patients with non-viable lesions showed a $67 \%$ reduction in the rate of generalized seizures with treatment $(P=0.006)$.

As far as we know, there have been no other meta-analyses undertaken to compare different durations of treatment.

Ongoing trials are still using regimens of 10 days albendazole (Gilman 2007) despite evidence that shorter treatment durations may be as effective. These findings have implications relating to cost and patient choice and adherence in what may be an expensive disease to treat; a recent study in India reported that the total costs per patient of treating seizures associated with a single cysticerci in the brain may be equivalent to around half the per capita Gross National Product of the country (Murthy 2007).

Current consensus guidelines for the treatment of neurocysticercosis (Garcia 2002; Nogales-Gaete 2006) do not give any definitive advice on anthelmintic treatment for patients with five or fewer, or more than 100 , viable lesions, or fewer than 100 non-viable lesions. This review presents evidence that albendazole treatment may reduce the recurrence of seizures in children with a single non-viable lesion, and reduce the persistence of lesions in neuroimaging in persons with small numbers of viable lesions. We did not find enough evidence to draw any conclusions on the safety and effectiveness of treatment for heavy parenchymal infection or extra-parenchymal (subarachnoid or ventricular) neurocysticercosis. There is also no current consensus on the use of corticosteroids when anthelmintics are used in cases of five or fewer viable cysts, or fewer than 100 non-viable lesions. This review presents evidence that corticosteroids may reduce the incidence of adverse events during treatment, even in people with only non-viable lesions or with small numbers of viable lesions. 


\section{AUTHORS' CONCLUSIONS}

\section{Implications for practice}

For children with parenchymal neurocysticercosis, and with small numbers of non-viable neurocysticercosis lesions in the brain, albendazole treatment at the standard dose may reduce the risk of recurrence of seizures in the medium term (six to 18 months). However, it is still unclear whether and how different groups benefit from albendazole treatment. There is some evidence that parasite clearance may be speeded up in patients with viable lesions, but no evidence that this has any impact on seizure recurrence. Short courses of seven days or less are as effective as longer courses, although there is not enough evidence to say what the optimum duration of treatment is. Adverse events during treatment, including headache, dizziness, and gastrointestinal symptoms, are common. There is some indirect evidence that they may be reduced by giving corticosteroids with the albendazole and prescribing albendazole for the minimum effective duration, but this needs to be evaluated through randomized comparisons.

There is not enough evidence available to assess the effects of praziquantel treatment in any group, or albendazole treatment in people with moderate or heavy infections or extra-parenchymal cysts. It is not known whether people who are HIV positive will respond to treatment in the same way, as it is assumed that most participants in the included studies were HIV negative.

\section{Implications for research}

Further good quality, randomized controlled trials are needed to assess the effectiveness of albendazole treatment in different groups of patients, including adults and children, and people with different stages and numbers of lesions (less than five, five to 100 and more than 100). Some trials should include participants with heavy parenchymal infections, and those with any kind of extra-parenchymal infection. At least one trial should also include participants who are HIV positive, as HIV infection is common in Africa where neurocysticercosis is also common. Trials should carefully assess, record, and analyse the outcomes likely to be of most interest to the patient, including adverse events during treatment, recurrence of seizures, and successful withdrawal of anti-epileptic drugs.

Once it is clear which groups might benefit from albendazole treatment, trials should assess the optimal dosage and duration of albendazole treatment for different groups of people with different forms of neurocysticercosis. These should compare treatment of seven days duration with shorter durations, including treatment for as few as three days.

\section{ACKNOWLEDGEMENTS}

This review replaces the Salinas 1999 Cochrane Review. The authors are grateful to Rodrigo Salinas and colleagues for having the opportunity to update this review by drafting a new protocol for the update. The authors would like to acknowledge that much of this protocol is based upon the Salinas 1999 Cochrane Review.

This document is an output from a project funded by the UK Department for International Development (DFID) for the benefit of developing countries. The views expressed are not necessarily those of DFID. 


\section{R E F E R E N C E S}

\section{References to studies included in this review}

\section{Alarcon 1989 \{published data only\}}

Alarcon F, Escalante L, Duenas G, Montalvo M, Roman M. Neurocysticercosis: short course of treatment with albendazole. Archives of Neurology 1989;46(11):1231-6.

\section{Alarcon 2001 \{published data only\}}

Alarcon F, Duenas G, Diaz M, Cevallos N, Estrada G. Short course of albendazole therapy for neurocysticercosis: a prospective randomized trial comparing three days, eight days and the control group without albendazole. Revista Ecuatoriana De Neurologia 2001;10:1-2

\section{Baranwal 1998 \{published data only\}}

* Baranwal AK, Singhi PD, Khandelwal N, Singhi SC. Albendazole therapy in children with focal seizures and single small enhancing computerized tomographic lesions: a randomized, placebo controlled, double-blind trial. Pediatric Infectious Disease Journal 1998;17(8):696-700.

Baranwal AK, Singhi PD, Khandelwal N, Singhi SC. Morphometry of single small enhancing computed tomographic lesions: outcome and effect of albendazole therapy. Journal of Tropical Pediatrics 2002;48:219-24.

Baranwal AK, Singhi PD, Singhi SC, Khandelwal N. Seizure recurrence and single small enhancing computed tomographic lesions: prognostic factors on long-term follow-up. Journal of Child Neurology 2001;6:443-4.

\section{Carpio 2008 \{published data only\}}

Carpio A, Kelvin EA, Bagiella E, Leslie D, Leon P, Andrews H, et al. Effects of albendazole treatment on neurocysticercosis: a randomised controlled trial. Journal of Neurology, Neurosurgery and Psychiatry 2008;79:1050-5.

\section{Cruz 1995 \{published data only\}}

Cruz I, Cruz ME, Carrasco F, Horton J. Neurocysticercosis: optimal dose treatment with albendazole. Journal of Neurological Sciences 1995;133(1-2):152-4.

\section{Das 2007 \{published data only\}}

Das K, Mondal GP, Banerjee M, Mukherjee BB, Singh OP. Role of antiparasitic therapy for seizures and resolution of lesions in neurocysticercosis patients: an 8 year randomised study. Journal of Clinical Neuroscience 2007;14(12):1172-7.

\section{De Souza 2009 \{published data only\}}

De Souza A, Thennarasu K, Yeshraj G, Kovoor JME, Nalini A. Randomized controlled trial of albendazole in new onset epilepsy and MRI confirmed solitary cerebral cysticercal lesion: effect on long-term seizure outcome. Journal of the Neurological Sciences 2009;276:108-14.

\section{Del Brutto 1999 \{published data only\}}

Del Brutto OH, Campos X, Sanchez J, Mosquera A. Single-day praziquantel versus 1-week albendazole for neurocysticercosis. Neurology 1999;23(52):1079-81.

\section{Garcia 1997 \{published data only\}}

Garcia H, Gilman R, Catacora M, Verastegui M, Gonzalez AE, Tsang VCW, and the Cysticercosis Working Group in Peru. Serologic evolution of neurocysticercosis patients after antiparasitic therapy. Journal of Infectious Diseases 1997; 175:486-9.

* Garcia HH, Gilman RH, Horton J, Martinez M, Herrera G, Altamirano J, et al. Albendazole therapy for neurocysticercosis: a prospective double-blind trial comparing 7 versus 14 days of treatment. Cysticercosis working group in Peru. Neurology 1997;48(5):1421-7.

\section{Garcia 2004 \{published data only\}}

Garcia HH, Pretell EJ, Gilman RH, Martinez SM, Moulton LH, Del Brutto $\mathrm{OH}$, et al. A trial of antiparasitic treatment to reduce the rate of seizures due to cerebral cysticercosis. New England Journal of Medicine 2004;350(3):249-58.

\section{Gogia 2003 \{published data only\}}

Gogia S, Talukdar B, Choudhury V, Arora BS. Neurocysticercosis in children: clinical findings and response to albendazole therapy in a randomized, double-blind, placebo controlled trial in newly diagnosed cases. Transactions of the Royal Society of Tropical Medicine and Hygiene 2003;97(4):416-21.

\section{Gongora-Rivera 2006 \{published data only\}}

Gongora-Rivera F, Soto-Hernandez JL, Gonzalez Esquivel D, Cook HJ, Marquez-Caraveo C, Hernandez Davila R, et al. Albendazole trials at 15 or $30 \mathrm{mg} / \mathrm{kg} /$ day for subarachnoid and intraventricular cysticercosis. Neurology 2006;66(3):436-8.

Kalra 2003 \{published data only\}

Kalra V, Dua T, Kumar V. Efficacy of albendazole and shortcourse dexamethasone treatment in children with 1 or 2 ring-enhancing lesions of neurocysticercosis: a randomised controlled trial. Journal of Pediatrics 2003;143(1):111-4.

\section{Kaur 2009 \{published data only\}}

Kaur S, Singhi P, Singhi S, Khandelwal N. Combination therapy with albendazole and praziquantel versus albendazole alone in children with seizures and single lesion neurocysticercosis. Pediatric Infectious Disease Journal 2009;28(5):403-6.

Padma 1994 \{published data only\} Padma MV, Behari M, Misra NK, Ahuja GK. Albendazole in single CT ring lesions in epilepsy. Neurology 1994;44:1344-6.

Padma 1995 \{published data only\}

Padma MV, Bahari M, Misra NK, Ahuja GK. Albendazole in neurocysticercosis. National Medical Journal of India 1995;8(6):255-8.

\section{Singhi 2000 \{published data only\}}

Singhi P, Ray M, Singhi S, Khandelwal N. Clinical spectrum of 500 children with neurocysticercosis and response to albendazole therapy. Journal of Child Neurology 2000;15(4):207-13. 
Singhi 2003 \{published data only\}

Singhi P, Dayal D, Khandelwal N. One week versus four weeks of albendazole therapy for neurocysticercosis in children: a randomized, placebo controlled double-blind trial. Pediatric Infectious Diseases Journal 2003;22(3):268-72.

Singhi 2004 \{published data only\}

Singhi P, Jain V, Khandelwal N. Corticosteroids versus albendazole for treatment of single small enhancing computed tomographic lesions in children with neurocysticercosis. Journal of Child Neurology 2004;19(5):323-7.

Sotelo 1988 \{published data only\}

Sotelo J, Escobedo F, Penagos P. Albendazole vs praziquantel for therapy for neurocysticercosis. A controlled trial. Archives of Neurology 1988;45(5):532-4.

Sotelo 1990 \{published data only\}

Sotelo J, Del Brutto OH, Penagos P, Escobedo F, Torres B, Rodriguez-Carbajal J, Rubio-Donnadieu F. Comparison of therapeutic regimen of anticystercal drugs for parenchymal brain cysticercosis. Journal of Neurology 1990;237:69-72.

\section{References to studies excluded from this review}

Antoniuk 1991 \{published data only\}

Antoniuk SA, Bruck I, Wittig E, Accorsi A. Neurocysticercosis in childhood: Il computed tomography of 24 patients according to symptomatic treatment and with praziquantel [Neurocysticercose na infancia: II tomografia computadoriza de 24 pacientes em relacao ao tratamento sintomatico e com praziquantel]. Arquivos de Neuro-Psiquiatria 1991;49(1):47-51.

\section{Bustos 2006 \{published data only\}}

Bustos JA, Pretell EJ, Llanos-Zavalaga, Gilman RH, Del Brutto OH, Garcia HH. Efficacy of a 3-day course of albendazole treatment in patients with a single neurocysticercosis cyst. Clinical Neurology and Neurosurgery 2006;108:193-4.

\section{Carpio 1995 \{published data only\}}

Carpio A, Santillan F, Leon P, Flores C, Hauser WA. Is the course of neurocysticercosis modified by treatment with antihelminthic agents?. Archives of Internal Medicine 1995;155(18):1982-8.

\section{Lopez-Gomez 2001 \{published data only\}}

Lopez-Gomez M, Castro N, Jung H, Sotelo J, Corona T. Optimization of the single-day praziquantel therapy for neurocysticercosis. Neurology 2001;57(10):1921-30.

\section{Marquez-Caraveo 2004 \{published data only\}}

Marquez-Caraveo C, Gongoro-Rivera F, Santos Zambrano J, Harnadez R, Soto-Hernandes JL. Pre-treatment with corticosteroids and a single cycle of high dose albendazole for subarachnoidal cysticercosis. Journal of Neurology, Neurosurgery and Psychiatry 2004;75:938-9.
Medina 1993 \{published data only\}

Medina MT, Genton P, Montoya MC, Cordova S, Dravet C, Sotelo J. Effect of anticysticercal treatment on the prognosis of epilepsy in neurocysticercosis: a pilot trial. Epilepsia 1993;34(6):1024-7.

\section{Proano 2006 \{published data only\}}

Proano JV, Madrazo I, Avelar F, Lopez-Felix B, Diaz G, Grijalva I. Medical treatment for neurocysticercosis characterized by giant subarachnoid cysts. New England Journal of Medicine 2001;345:879-85.

\section{Sanchetee 1994 \{published data only\}}

Sanchetee PC, Venkataraman S, Dhamija RM, Roy AK. Albendazole therapy for neurocysticercosis. Journal of the Association of Physicians in India 1994;42(2):116-7.

Thussu 2008 \{published data only\}

Thussu A, Chattopadhyay A, Sawhney AMS, Khandelwal N. Albendazole therapy for single small enhancing CT lesions (SSECTL) in the brain in epilepsy. Journal of Neurology, Neurosurgery and Psychiatry 2008;79:272-5.

\section{References to studies awaiting assessment \\ Cruz 1991 \{published data only\}}

Cruz M, Cruz I, Horton J. Albendazole versus praziquantel in the treatment of cerebral cysticercosis: clinical evaluation. Transactions of the Royal Society of Tropical Medicine and Hygiene 1991;85(2):244-7.

Cruz M, Cruz I, Horton J. Clinical evaluation of albendazole and praziquantel in the treatment of cerebral cysticercosis. Southeast Asian Journal of Tropical Medicine and Public Health 1991;22:279-83.

Pretell 2000 \{published data only\}

Pretell EJ, Garcia HH, Custodio N, Padilla C, Alvarado M, Gilman $\mathrm{RH}$, et al. Short regimen of praziquantel in the treatment of single brain enhancing lesions. Clinical Neurology and Neurosurgery 2000;102(4):215-8.

Takayanagui 1992 \{published data only\}

Takayanagui OM, Jardim E. Therapy for neurocysticercosis: comparison between albendazole and praziquantel. Archives of Neurology 1992;49(3):290-4.

\section{References to ongoing studies}

Gilman 2007 \{published data only\}

Randomized study of albendazole in patients with epilepsy due to neurocysticercosis. Ongoing study May 2000.

\section{Additional references}

\section{Burneo 2005}

Burneo G. Neurocysticercosis. http:www/eMedicine.com/neuro/ topic629.htm (accessed 22 May 2006) 2005. 


\section{DeGiorgio 2004}

De Giorgio CM, Medina MT, Duron R, Zee C, Escueta SP. Neurocysticercosis. Epilepsy Currents 2004;4(3):107-11.

\section{Del Brutto 2006}

Del Brutto OH, Roos KL, Coffey CS, Garcia HH. Meta-analysis: cysticidal drugs for neurocysticercosis: albendazole and praziquantel. Annals of Internal Medicine 2006;145(1):43-51.

\section{Garcia 2002}

Garcia HH, Evans CA, Nash TE, Takayanagui OM, White AC Jr, Botero D, et al. Current consensus guidelines for treatment of neurocysticercosis. Clinical Microbiology Reviews 2002;15(4):747-56.

\section{Jüni 2001}

Jüni P, Altman DG, Egger M. Systematic reviews in health care: assessing the quality of controlled clinical trials. BMJ 2001;323(7303):42-6.

\section{Kossoff 2005}

Kossoff EH. Neurocysticercosis. http:/www.emedicine.com/ped/ topic1573.htm>eMedicine (accessed February 2006) 2005.

\section{Lefebvre 2008}

Lefebvre C, Manheimer E, Glanville J. Chapter 6: Searching for studies. In: Higgins JPT, Green S (editors). Cochrane Handbook for Systematic Reviews of Interventions Version 5.0.0 (updated February 2008). The Cochrane Collaboration, 2008. Available from www.cochrane-handbook.org.

\section{Leite 2000}

Leite JP, Terra-Bustamante VC, Fernandes RMF, Santos AL, Chimelli L, Sakomoto AC, et al. Calcified neurocysticercosis lesions and postsurgery seizure control in temporal lobe epilepsy. Neurology 2000;55(10):1485-91.

\section{Mazumdar 2007}

Mazumdar M, Pandharipande P, Poduri A. Does albendazole affect seizure remission and computed tomography response in children with neurocysticercosis? A systematic review and meta-analysis. Journal of Child Neurology 2007;22(2):135-42.

\section{Murthy 2006}

Murthy JM. Seizures associated with solitary cystericus granuloma: antiepileptic drugs for so long?. Neurology India 2006;54(2):141-2.

\section{Murthy 2007}

Murthy JMK, Rajshekar G. Economic evaluation of seizures associated with solitary cysticercus granuloma. Neurology India 2007;55(1):42-5.

\section{Nogales-Gaete 2006}

Nogales-Gaete J, Arriagada CM, Salinas RR. Treatment of neurocysticercosis: a review [Tratamiento de la neurocisticercosi: revision critica]. Revista Médica de Chile 2006;134:789-96

\section{Review Manager 5 [Computer program]}

The Nordic Cochrane Centre, The Cochrane Collaboration. Review Manager (RevMan). Version 5.0. Copenhagen: The Nordic Cochrane Centre, The Cochrane Collaboration, 2008.

\section{Roman 2000}

Roman G, Sotelo J, Del Brutto O, Flissier A, Dumas M, Wadia N, et al. A proposal to declare neurocysticercosis an international reportable disease. Bulletin of the World Health Organization 2000;78(3):399-406.

\section{References to other published versions of this review Salinas 1999}

Salinas R, Prasad K. Drugs for treating neurocysticercosis (tapeworm infection of the brain). Cochrane Database of Systematic Reviews 1999, Issue 4. [Art. No.: CD000215. DOI: 10.1002/14651858.CD000215.pub2]

* Indicates the major publication for the study

\section{CHARACTERISTICS OF STUDIES}

Characteristics of included studies [ordered by study ID]

\section{Alarcon 1989}

Methods Randomized controlled trial

Duration: dates not supplied. Participants followed up for 4 months

Participants Number: 23 enrolled; numbers of males and females not presented

Inclusion criteria: adults and children aged $>13$ years, with 1 to 3 parenchymal cysts $>10 \mathrm{~mm}$ without perilesional oedema, good general health and stable neurological disease

Exclusion criteria: parenchymal cysts with ring enhancement and oedema surrounding the lesions, pregnant women

Type of lesion: viable 
Alarcon 1989 (Continued)

Interventions Group 1. Albendazole: $15 \mathrm{mg} / \mathrm{kg}$ bodyweight for 3 days

Group 2. Albendazole: $15 \mathrm{mg} / \mathrm{kg}$ bodyweight for 30 days

Group 3. No albendazole

\begin{tabular}{ll}
\hline Outcomes & $\begin{array}{l}\text { Included in the review: number of cysts and total diameter of cysts at baseline and } 1 \text { day, } 30 \text { days, and } 3 \\
\text { months after treatment finishes. Adverse events }\end{array}$ \\
\hline Notes & Location: Ecuador \\
& Source of funding: not stated
\end{tabular}

\section{Risk of bias}

\begin{tabular}{|c|c|c|}
\hline Bias & Authors' judgement & Support for judgement \\
\hline $\begin{array}{l}\text { Adequate sequence gener- } \\
\text { ation? }\end{array}$ & Unclear risk & $\begin{array}{l}\text { Quote: "randomly allocated" } \\
\text { Decision: probably done, but unclear }\end{array}$ \\
\hline Allocation concealment? & Unclear risk & Not described \\
\hline $\begin{array}{l}\text { Blinding? } \\
\text { All outcomes }\end{array}$ & Unclear risk & $\begin{array}{l}\text { Not described. Placebos were not used and different groups received fol- } \\
\text { low-up scans at different times } \\
\text { Decision: unclear, probably not done }\end{array}$ \\
\hline $\begin{array}{l}\text { Incomplete outcome data } \\
\text { addressed? } \\
\text { All outcomes }\end{array}$ & Low risk & 23 randomized and follow-up data available for all (100\%) \\
\hline $\begin{array}{l}\text { Free of selective report- } \\
\text { ing? }\end{array}$ & Low risk & $\begin{array}{l}\text { No evidence of selective reporting; outcomes reported individually for all par- } \\
\text { ticipants }\end{array}$ \\
\hline Free of other bias? & Low risk & No evidence of other bias \\
\hline
\end{tabular}

\section{Alarcon 2001}

\begin{tabular}{ll}
\hline Methods & Randomized controlled trial \\
& $\begin{array}{l}\text { Duration: participants recruited between January } 1989 \text { and December 1996, and followed up for } 12 \\
\text { months }\end{array}$ \\
\hline Participants & $\begin{array}{l}\text { Number: } 95 \text { enrolled, data available for } 83 \text { ( } 36 \text { male, } 47 \text { female) } \\
\text { Inclusion criteria: adults with neurological signs and symptoms and } 1 \text { to } 6 \text { non-enhancing parenchymal } \\
\text { cysts without perilesional oedema } \\
\text { Exclusion criteria: ring or nodular cysts, oedema surrounding the lesions, subarachnoid or intraventric- } \\
\text { ular cysts, hydrocephalus, previous treatment with albendazole or praziquantel, pregnant women, in- } \\
\text { tracranial hypertension } \\
\text { Type of lesion: viable }\end{array}$ \\
\hline
\end{tabular}

Interventions

Group 1. Albendazole: $15 \mathrm{mg}$ per kg bodyweight for 3 days

Group 2. Albendazole: $15 \mathrm{mg}$ per kg bodyweight for 8 days

Group 3. No albendazole 
Alarcon 2001 (Continued)

Outcomes Included in the review: number of cysts at baseline, 3 months, and 6 months; persistence of cysts at 3 months and 12 months; number of seizures per year at baseline and 12 months; adverse events associated with treatment

Lotes $\quad$ Location: Ecuador
Source of funding: not stated

\section{Risk of bias}

\begin{tabular}{lll}
\hline Bias & Authors' judgement & Support for judgement \\
\hline $\begin{array}{l}\text { Adequate sequence gener- } \\
\text { ation? }\end{array}$ & Unclear risk & Method not described, but trial described as 'randomized' \\
& & Decision: unclear, but probably done \\
\hline Allocation concealment? & Unclear risk & Not described \\
& & Decision: unclear \\
\hline $\begin{array}{l}\text { Blinding? } \\
\text { All outcomes }\end{array}$ & Low risk & $\begin{array}{l}\text { Quote: "Evaluation of the number of cysts on CT at baseline and at follow-up } \\
\text { was performed by a single neuroradiologist blinded to the treatment alloca- } \\
\text { tion" }\end{array}$ \\
\hline $\begin{array}{l}\text { Incomplete outcome data } \\
\text { addressed? }\end{array}$ & Low risk & $\begin{array}{l}\text { 95 participants randomized; } 8 \text { excluded before starting treatment, } 4 \text { lost to fol- } \\
\text { low up (87\% included in the analysis) }\end{array}$ \\
\hline $\begin{array}{l}\text { Free of selective report- } \\
\text { ing? }\end{array}$ & Low risk & No evidence of selective reporting \\
\hline \begin{tabular}{l} 
Free of other bias? \\
\hline
\end{tabular} & Low risk & No evidence of other bias \\
\hline
\end{tabular}

Baranwal 1998

$\begin{array}{ll}\text { Methods } & \text { Randomized controlled trial } \\ & \text { Duration: dates not supplied. Participants followed up for } 24 \text { months. }\end{array}$
Participants Number: 63 enrolled, 57 included in analysis ( 33 male, 24 female)
Inclusion criteria: children aged 2 years to 12 years with a single small enhancing lesion in brain parenchyma plus seizures for less than 3 months
Exclusion criteria: neurologic deficit or suspected tuberculosis
Type of lesion: non-viable
Interventions Group 1. Albendazole: $15 \mathrm{mg}$ per kg bodyweight for 28 days, plus 1 to $2 \mathrm{mg}$ prednisolone per day for 5 days
Group 2. Placebo, plus 1 to $2 \mathrm{mg}$ prednisolone per day for 5 days
Outcomes Included in the review: recurrence of seizures at 3 months after treatment; persistence of lesion at 1 month and 3 months; recurrence of seizures 8 months after tapering anticonvulsants after 18 to 24 months seizure-free following treatment

Not included in the review: calcification of lesion at 3 months; lesion diameter at baseline and 1 month 
Baranwal 1998 (Continued)
Notes
Location: India
Source of funding: not stated

\section{Risk of bias}

\begin{tabular}{|c|c|c|}
\hline Bias & Authors' judgement & Support for judgement \\
\hline $\begin{array}{l}\text { Adequate sequence gener- } \\
\text { ation? }\end{array}$ & Low risk & $\begin{array}{l}\text { Quote: "...numbered in a random sequence using a random number table" } \\
\text { Decision: done }\end{array}$ \\
\hline Allocation concealment? & Low risk & $\begin{array}{l}\text { Quote: "Envelopes containing albendazole or placebo capsules for the full } \\
\text { course of therapy were prepared in advance and numbered in a random se- } \\
\text { quence" } \\
\text { Decision: done }\end{array}$ \\
\hline $\begin{array}{l}\text { Blinding? } \\
\text { All outcomes }\end{array}$ & Low risk & $\begin{array}{l}\text { Quote: "All persons involved in the study i.e. patient, clinical investigator and } \\
\text { neuroradiologist were blind to the random allocation. Results were decoded } \\
\text { after completion of } 6 \text { months of study to identify the groups" } \\
\text { Decision: done }\end{array}$ \\
\hline $\begin{array}{l}\text { Incomplete outcome data } \\
\text { addressed? } \\
\text { All outcomes }\end{array}$ & Low risk & 63 randomized, 6 lost to follow up (90\% included in the analysis) \\
\hline $\begin{array}{l}\text { Free of selective report- } \\
\text { ing? }\end{array}$ & Low risk & No evidence of selective reporting \\
\hline Free of other bias? & Low risk & No evidence of other bias \\
\hline
\end{tabular}

\section{Carpio 2008}

\begin{tabular}{ll}
\hline Methods & Randomized controlled trial \\
& Duration: dates not supplied. Participants followed up for 12 months \\
Inclusion of randomized participants in the analysis: $161 / 178=90 \%$ (in addition, 7 died)
\end{tabular}

\section{Participants}

Number: 178 enrolled, 97 male, 77 female; 4 with missing data on sex

Inclusion criteria: any age or gender with new onset symptoms associated with neurocysticercosis within 2 months prior to recruitment, and neurocysticercosis cysts an axial CT or MRI imaging of the brain. Could include 1 or more active parenchymal cysts, degenerative or transitional parenchymal cysts, or cysts with a extra-parenchymal location.

Exclusion criteria: having only calcified cysts, pregnancy, papilloedema, active tuberculosis, syphilis, ocular cysticercosis, active gastric ulcers or any progressive or life-threatening disorder

Type of lesion: viable or non-viable cysts, or a combination of the two

Interventions

Group 1: For participants weighing more than $50 \mathrm{~kg}, 400 \mathrm{mg}$ of albendazole every 12 hours for 8 days. For participants weighing less than $50 \mathrm{~kg}$, including children, $15 \mathrm{mg}$ per $\mathrm{kg}$ bodyweight per day for 8 days. Participants weighing over $50 \mathrm{~kg}$ also received $75 \mathrm{mg}$ prednisolone daily for 8 days, then $50 \mathrm{mg}$ per day for 1 week, then $25 \mathrm{mg}$ per day for 1 week. Participants weighing less than $50 \mathrm{~kg}$ received 1.5 $\mathrm{mg}$ per $\mathrm{kg}$ bodyweight prednisone for 8 days, then $1 \mathrm{mg}$ per $\mathrm{kg}$ for 1 week, then $0.5 \mathrm{mg}$ for 1 week. 
Carpio 2008 (Continued)

Group 2: Placebo with an identical appearance to albendazole, plus prednisolone as for Group 1

Outcomes Included in the review: freedom from seizures for 12 months following treatment; mean time seizurefree following treatment; freedom from cysts 1 month, 6 months and 12 months following treatment; reduction in the number of cysts 1 month, 6 months and 12 months following treatment; deaths due to cysticercosis; all-cause deaths; adverse events during treatment, and during the first month following treatment

Lotes $\begin{aligned} & \text { Lotion: Ecuador } \\ & \text { Source of funding: NINDS grant R01-NS39403. Glaxo/SKB and Acromax Co supplied the active drug and } \\ & \text { placebo }\end{aligned}$

\section{Risk of bias}

\begin{tabular}{|c|c|c|}
\hline Bias & Authors' judgement & Support for judgement \\
\hline \multirow[t]{2}{*}{$\begin{array}{l}\text { Adequate sequence gener- } \\
\text { ation? }\end{array}$} & Low risk & $\begin{array}{l}\text { Quote: "Patients were allocated to treatment group according to a stratified } \\
\text { block randomisation schedule. Two strata were considered: centre (sex cen- } \\
\text { tres) and location of the cyst (parenchymal versus extraparenchymal). Permut- } \\
\text { ed blocks of size } 4 \text { and } 6 \text { were used to balance the treatment allocation within } \\
\text { each stratum" }\end{array}$ \\
\hline & & Decision: done \\
\hline \multirow[t]{2}{*}{ Allocation concealment? } & Low risk & $\begin{array}{l}\text { Quote: "The randomisation lists were kept in electronic form on a computer } \\
\text { accessible only to the statistician" }\end{array}$ \\
\hline & & Decision: done \\
\hline \multirow[t]{2}{*}{$\begin{array}{l}\text { Blinding? } \\
\text { All outcomes }\end{array}$} & Low risk & $\begin{array}{l}\text { Quotes: "All other research staff were blinded to the treatment arm"... "dou- } \\
\text { ble-blind, placebo controlled trial" }\end{array}$ \\
\hline & & Decision: done \\
\hline $\begin{array}{l}\text { Incomplete outcome data } \\
\text { addressed? } \\
\text { All outcomes }\end{array}$ & Low risk & $\begin{array}{l}\text { Of } 178 \text { participants, } 161 \text { (90\%) were followed up and included in the analysis. } \\
\text { In addition, } 7 \text { died. }\end{array}$ \\
\hline $\begin{array}{l}\text { Free of selective report- } \\
\text { ing? }\end{array}$ & Low risk & No evidence of selective reporting \\
\hline Free of other bias? & Low risk & No evidence of other bias \\
\hline
\end{tabular}

Cruz 1995

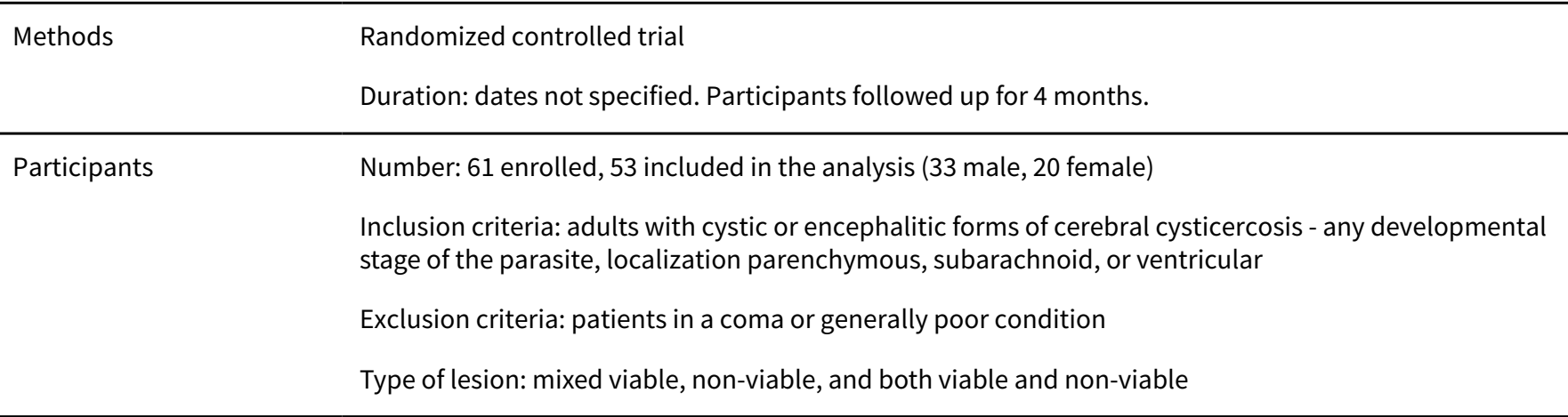


Cruz 1995 (Continued)

Group 1. Albendazole: $800 \mathrm{mg}$ per day for 8 days
Group 2. Albendazole: $800 \mathrm{mg}$ per day for 15 days
Group 3. Albendazole: $800 \mathrm{mg}$ per day for 30 days

Outcomes Included in the review: persistence of cysts at 3 months; number of cysts at baseline and 3 months; symptom change at 3 months; adverse events

Lotes $\quad$ Lotion: Ecuador
Source of funding: partially funded by SmithKline Beecham Pharmaceuticals

\section{Risk of bias}

\begin{tabular}{|c|c|c|}
\hline Bias & Authors' judgement & Support for judgement \\
\hline $\begin{array}{l}\text { Adequate sequence gener- } \\
\text { ation? }\end{array}$ & Unclear risk & $\begin{array}{l}\text { Quote: "...were randomised to one of } 3 \text { different treatment groups" } \\
\text { Decision: unclear, probably done }\end{array}$ \\
\hline Allocation concealment? & Unclear risk & $\begin{array}{l}\text { Not described } \\
\text { Decision: unclear }\end{array}$ \\
\hline $\begin{array}{l}\text { Blinding? } \\
\text { All outcomes }\end{array}$ & Unclear risk & $\begin{array}{l}\text { Not described. Participants were treated for different durations, without the } \\
\text { use of placebos. } \\
\text { Decision: unclear, probably not done }\end{array}$ \\
\hline $\begin{array}{l}\text { Incomplete outcome data } \\
\text { addressed? } \\
\text { All outcomes }\end{array}$ & Low risk & Of 61 participants randomized, 53 completed 3 months follow up ( $87 \%)$ \\
\hline $\begin{array}{l}\text { Free of selective report- } \\
\text { ing? }\end{array}$ & Low risk & No evidence of selected reporting \\
\hline Free of other bias? & Low risk & No evidence of other bias \\
\hline
\end{tabular}

Das 2007

\begin{tabular}{ll}
\hline Methods & Randomized controlled trial \\
& Duration: between January 1997 and January 2005
\end{tabular}

Participants Number: 300 enrolled (178 male, 122 female)

Inclusion criteria: adults presenting with recent-onset seizures, with CT and MRI scan results strongly suggestive of neurocysticercosis and at least 2 lesions with ring enhancement, of which at least 1 was in the vesicular stage, and antibodies against neurocysticercosis detected by ELISA on at least 3 occasions

Exclusion criteria: primary seizure disorder, family history of seizure, pre-existing focal neurological deficit, or any metabolic or hereditary disease

Type of lesion: mixed viable and non-viable

Interventions

Group 1. $15 \mathrm{mg}$ per kg bodyweight albendazole daily for 14 days, plus $2 \mathrm{mg}$ dexamethasone orally at 8hour intervals for 14 days, plus anti-epileptic drugs at appropriate doses. Dexamethasone tapered off over time. 
Das 2007 (Continued)

Group 2. Placebo plus anti-epileptic drugs

Outcomes Included in the review: seizures, hospital admissions, and resolution of lesions at 3 months, 6 months, 1 year, 2 years, 3 year and 4 years

\begin{tabular}{ll}
\hline Notes & Location: India \\
Source of funding: Burdwan Medical College and Hospital
\end{tabular}

\section{Risk of bias}

\begin{tabular}{|c|c|c|}
\hline Bias & Authors' judgement & Support for judgement \\
\hline $\begin{array}{l}\text { Adequate sequence gener- } \\
\text { ation? }\end{array}$ & Unclear risk & $\begin{array}{l}\text { Quote: "The patients were randomly allocated into two groups" } \\
\text { Decision: unclear, probably done }\end{array}$ \\
\hline Allocation concealment? & Unclear risk & $\begin{array}{l}\text { Not described } \\
\text { Decision: unclear }\end{array}$ \\
\hline $\begin{array}{l}\text { Blinding? } \\
\text { All outcomes }\end{array}$ & Unclear risk & $\begin{array}{l}\text { Placebos used, but blinding not described for investigators and medical staff } \\
\text { Decision: unclear }\end{array}$ \\
\hline $\begin{array}{l}\text { Incomplete outcome data } \\
\text { addressed? } \\
\text { All outcomes }\end{array}$ & Low risk & $\begin{array}{l}300 \text { randomized, } 2 \text { died within } 3 \text { months, } 298 \text { followed up for } 5 \text { years ( } 100 \% \text { fol- } \\
\text { low up) }\end{array}$ \\
\hline $\begin{array}{l}\text { Free of selective report- } \\
\text { ing? }\end{array}$ & Low risk & No evidence of selective reporting \\
\hline Free of other bias? & Low risk & No evidence of other bias \\
\hline
\end{tabular}

\section{De Souza 2009}

\begin{tabular}{ll}
\hline Methods & Randomized controlled trial \\
& $\begin{array}{l}\text { Duration: participants enrolled between May } 2002 \text { and October } 2003 \text { and followed up for up to } 64 \\
\text { months (mean } 31 \text { months) }\end{array}$
\end{tabular}

Number: 123 enrolled, 103 included in the analysis (59 male, 44 female)
Inclusion criteria: all patients presenting with new onset focal or generalized seizures with MRI-con-
firmed solitary cysticercal lesion in the brain parenchyma
Exclusion criteria: past history of epilepsy, received albendazole or praziquantel in the past, evidence
of other lesions on CT or MRI, significant neurological deficits, raised intracranial pressure or seizures
refractory to acute treatment
Types of lesion: non-viable

Interventions Group 1: Anti-epileptic drugs only

Group 2: Anti-epileptic drugs plus albendazole $15 \mathrm{mg}$ per kg bodyweight per day for 28 days 
De Souza 2009 (Continued)

Outcomes
Included in the review: time to becoming seizure-free; total number of seizures from onset of illness until the last visit; duration of anti-epileptic drug therapy; number of months seizure free at the last visit; number of months taken off anti-epileptic drugs at last visit; disappearance of calcification of cysts

Not included in the review: types of seizure; mean cyst area; perilesional oedema

Notes $\quad$ Location: India
Source of funding: Indian Council for Medical Research

\section{Risk of bias}

\begin{tabular}{|c|c|c|}
\hline Bias & Authors' judgement & Support for judgement \\
\hline \multirow[t]{2}{*}{$\begin{array}{l}\text { Adequate sequence gener- } \\
\text { ation? }\end{array}$} & Low risk & $\begin{array}{l}\text { Quote: "The patients were randomised to two groups by means of a random } \\
\text { number table" }\end{array}$ \\
\hline & & Decision: done \\
\hline \multirow[t]{2}{*}{ Allocation concealment? } & Unclear risk & Not described \\
\hline & & Decision: unclear \\
\hline \multirow{2}{*}{$\begin{array}{l}\text { Blinding? } \\
\text { All outcomes }\end{array}$} & Unclear risk & Not described. Placebos not used \\
\hline & & Decision: unclear, probably not done \\
\hline $\begin{array}{l}\text { Incomplete outcome data } \\
\text { addressed? } \\
\text { All outcomes }\end{array}$ & Low risk & $\begin{array}{l}\text { Of } 123 \text { participants recruited, } 103(84 \%) \text { had a minimum follow up of } 12 \\
\text { months, and so were included. It was stated that the demographic profile, } \\
\text { seizure type and MRI findings in the } 20 \text { excluded participants did not differ } \\
\text { from those included. }\end{array}$ \\
\hline $\begin{array}{l}\text { Free of selective report- } \\
\text { ing? }\end{array}$ & Low risk & No evidence of selective reporting \\
\hline Free of other bias? & Low risk & No evidence of other bias \\
\hline
\end{tabular}

\section{Del Brutto 1999}

\begin{tabular}{ll}
\hline Methods & Randomized controlled trial \\
& Duration: dates not specified \\
\hline Participants & Number: 20 enrolled (8 male, 12 female) \\
& Inclusion criteria: adults with less than 20 parenchymal brain cysts with no evidence of surrounding in- \\
flammation & Exclusion criteria: mixed forms of the disease \\
& Type of lesion: viable \\
\hline Interventions & $\begin{array}{l}\text { Group } 1 . \text { Albendazole: } 15 \text { mg per kg for } 7 \text { days plus prednisolone } 1 \text { mg per kg bodyweight per day, until } \\
\text { Group } 2 . \text { Praziquantel: } 100 \text { mg per kg bodyweight for } 1 \text { day, plus } 2 \text { mg doses of intravenous dexametha- } \\
\text { sone administered } 6 \text { and } 8 \text { hours after the last dose of praziquantel }\end{array}$ \\
\end{tabular}


Del Brutto 1999 (Continued)

Outcomes

Included in the review: number of cysts at baseline and 3 months; persistence of cysts at 3 months; persistence of seizures at 6 to 12 months; adverse events associated with treatment

Not included in the review: improvement in motor deficit at 6 to 12 months

Source of funding: not stated

\section{Risk of bias}

\begin{tabular}{lll}
\hline Bias & Authors' judgement & Support for judgement \\
\hline $\begin{array}{ll}\text { Adequate sequence gener- } \\
\text { ation? }\end{array}$ & Low risk & $\begin{array}{l}\text { Quote: "...patients were randomly allocated (from a table of random numbers) } \\
\text { to one of two treatment groups" } \\
\text { Decision: done }\end{array}$ \\
\hline Allocation concealment? & Unclear risk & Not described \\
\hline $\begin{array}{l}\text { Blinding? } \\
\text { All outcomes }\end{array}$ & Locision: unclear \\
\hline $\begin{array}{l}\text { Incomplete outcome data } \\
\begin{array}{l}\text { Addressed? } \\
\text { All outcomes }\end{array}\end{array}$ & Low risk & $\begin{array}{l}\text { Quote: "All CT studies were independently reviewed by two experienced radi- } \\
\text { ologists, blinded to the therapy used..." }\end{array}$ \\
\hline $\begin{array}{l}\text { Free of selective report- } \\
\text { ing? }\end{array}$ & Low risk & Decision: done \\
\hline \begin{tabular}{l} 
Free of other bias? \\
\hline
\end{tabular} & Low risk & No evidence of selective reporting \\
\hline
\end{tabular}

Garcia 1997

\begin{tabular}{ll} 
Methods & Randomized controlled trial \\
& Duration: dates not supplied. Participants followed up for 12 months. \\
\hline Participants & Number: 55 enrolled ( 32 male, 23 female) \\
& $\begin{array}{l}\text { Inclusion criteria: adults with live cysts or nodular enhancing lesions, with or without contrast en- } \\
\text { hancement, in any part of the brain. Positive immunoblot }\end{array}$ \\
& Exclusion criteria: pregnant or lactating women \\
& Type of lesion: viable or mixed (41), non-viable (9) \\
\hline $\begin{array}{l}\text { Group } 1 . \text { Albendazole: } 400 \mathrm{mg} \text { daily for } 14 \text { days plus dexamethasone } 1.5 \mathrm{mg} 3 \text { times daily for } 5 \text { days and } \\
0.5 \mathrm{mg} 3 \text { times daily for } 5 \text { days then } 0.5 \mathrm{mg} 3 \text { times daily for } 2 \text { days } \\
\text { Group } 2 \text {. Albendazole: } 400 \mathrm{mg} \text { daily for } 7 \text { days plus dexamethasone } 1.5 \mathrm{mg} 3 \text { times daily for } 5 \text { days and } \\
0.5 \mathrm{mg} 3 \text { times daily for } 5 \text { days then } 0.5 \mathrm{mg} 3 \text { times daily for } 2 \text { days }\end{array}$ \\
\hline
\end{tabular}

\section{Outcomes}

Included in the review: 


\begin{tabular}{|c|c|c|}
\hline Notes & \multicolumn{2}{|c|}{$\begin{array}{l}\text { Source of funding: funded in part by grants number 1-U01 A135894-01 from the National Institutes for } \\
\text { Health; and from SmithKline Beecham Pharmaceuticals, London, UK }\end{array}$} \\
\hline \multicolumn{3}{|l|}{ Risk of bias } \\
\hline Bias & Authors' judgement & Support for judgement \\
\hline $\begin{array}{l}\text { Adequate sequence gener- } \\
\text { ation? }\end{array}$ & Low risk & $\begin{array}{l}\text { Quote: "Patients were blindly assigned to one of two treatment groups using a } \\
\text { previously assigned randomization schedule" } \\
\text { Decision: done }\end{array}$ \\
\hline Allocation concealment? & Unclear risk & $\begin{array}{l}\text { Quote: "Patients were blindly assigned to one of two treatment groups using a } \\
\text { previously assigned randomization schedule" } \\
\text { Decision: unclear, but probably done }\end{array}$ \\
\hline $\begin{array}{l}\text { Blinding? } \\
\text { All outcomes }\end{array}$ & Unclear risk & $\begin{array}{l}\text { Quote: "CT scans were read by an experienced reader, blinded to the therapy } \\
\text { used" } \\
\text { Decision: done }\end{array}$ \\
\hline $\begin{array}{l}\text { Incomplete outcome data } \\
\text { addressed? } \\
\text { All outcomes }\end{array}$ & Low risk & 55 participants randomized, 50 included in the analysis (91\%) \\
\hline $\begin{array}{l}\text { Free of selective report- } \\
\text { ing? }\end{array}$ & Low risk & No evidence of selective reporting \\
\hline Free of other bias? & Low risk & No evidence of other bias \\
\hline
\end{tabular}

\section{Garcia 2004}

\begin{tabular}{ll}
\hline Methods & Randomized controlled trial \\
& Duration: recruitment between January 1997 and March 1999. Follow up for 6 months.
\end{tabular}

\begin{tabular}{ll}
\hline Participants & Number: 120 enrolled (61 male, 59 female) \\
& Inclusion criteria: adults with fewer than 20 viable parenchymal cysts plus 1 or more seizures in the pre- \\
& vious 6 months \\
& $\begin{array}{l}\text { Exclusion criteria: primary generalized seizures, history of antiparasitic treatment, evidence on CT of } \\
\text { other diseases, moderate or severe intracranial hypertension, status epilepticus, focal neurological } \\
\text { deficits, unstable vital signs, impending risk of death, or pregnancy. }\end{array}$ \\
& Type of lesion: viable \\
\hline Interventions & $\begin{array}{l}\text { Group } 1 . \text { Albendazole: } 400 \text { mg every } 12 \text { hours and } 2 \text { mg dexamethasone every } 8 \text { hours for } 10 \text { days } \\
\text { Group 2. Placebos }\end{array}$ \\
\hline Outcomes & $\begin{array}{l}\text { Included in the review: recurrence of seizures during months } 2 \text { to } 30 ; \text { partial seizures in month } 1, \\
\text { months } 2 \text { to } 12 \text { and months } 13 \text { to } 30, \text { and following tapering of anti-epileptic drugs; seizures with gen- }\end{array}$
\end{tabular}


Garcia 2004 (Continued)

eralization in month 1, months 2 to 12 and months 13 to 30 , and following tapering of anti-epileptic drugs; number of cysts at baseline and 6 months; persistence of seizures at 6 months; adverse events associated with treatment

\begin{tabular}{ll}
\hline Notes & Location: Peru \\
Source of funding: not stated
\end{tabular}

\section{Risk of bias}

\begin{tabular}{|c|c|c|}
\hline Bias & Authors' judgement & Support for judgement \\
\hline $\begin{array}{l}\text { Adequate sequence gener- } \\
\text { ation? }\end{array}$ & Low risk & $\begin{array}{l}\text { Random assignment in blocks of } 6 \text { according to a pre-established list taken } \\
\text { from a random-numbers table }\end{array}$ \\
\hline Allocation concealment? & Low risk & $\begin{array}{l}\text { Randomization performed from remote site by a statistician not otherwise in- } \\
\text { volved in the study. All drugs and placebos were administered by the study } \\
\text { personnel, who received them in sealed, opaque, sequentially numbered en- } \\
\text { velopes }\end{array}$ \\
\hline $\begin{array}{l}\text { Blinding? } \\
\text { All outcomes }\end{array}$ & Low risk & Blinded all study participants and personnel \\
\hline $\begin{array}{l}\text { Incomplete outcome data } \\
\text { addressed? } \\
\text { All outcomes }\end{array}$ & Low risk & $\begin{array}{l}120 \text { randomized, } 116 \text { received study medication, } 2 \text { were excluded from the } \\
\text { analysis, } 14 \text { lost to follow up }(100 / 120=83 \%) \text {. The reasons for all withdrawals } \\
\text { were clearly documented. }\end{array}$ \\
\hline $\begin{array}{l}\text { Free of selective report- } \\
\text { ing? }\end{array}$ & Low risk & No evidence of selective reporting \\
\hline Free of other bias? & Low risk & No evidence of other bias \\
\hline
\end{tabular}

Gogia 2003

$\begin{array}{ll}\text { Methods } & \text { Randomized controlled trial } \\ \text { Duration: recruitment March to July } 2000\end{array}$

Participants Number: 72 enrolled (38 male, 34 female)

Inclusion criteria: children aged 18 months to 12 years with ring-enhancing lesions in brain parenchyma, plus seizures without a history of epilepsy

Exclusion criteria: tuberculosis, known epilepsy on anti-epileptic medication, chronic central nervous system disorders. CT scans showing disc, nodular or calcific lesions.

Type of lesion: non-viable

Group 1. Prednisolone: $2 \mathrm{mg}$ per kg for 3 days followed by albendazole 15 mg per kg bodyweight for 28
days
Group 2. Prednisolone: $2 \mathrm{mg}$ per kg for 3 days followed by placebo for 28 days

Outcomes Included in the review: persistence of lesions at 6 months; recurrence of seizures at 6 months

Not included in the review: calcification of lesions at 6 months; nodular lesions at 6 months

Notes

Location: India 
Gogia 2003 (Continued)

Source of funding: not stated

\section{Risk of bias}

\begin{tabular}{|c|c|c|}
\hline Bias & Authors' judgement & Support for judgement \\
\hline \multirow[t]{2}{*}{$\begin{array}{l}\text { Adequate sequence gener- } \\
\text { ation? }\end{array}$} & Low risk & $\begin{array}{l}\text { Quote: "The enrolled children were randomized using a random number ta- } \\
\text { ble" }\end{array}$ \\
\hline & & Decision: done \\
\hline \multirow[t]{2}{*}{ Allocation concealment? } & Low risk & $\begin{array}{l}\text { Quote: "...coded as drug A or drug B..." "The drugs were dispensed in coded en- } \\
\text { velopes" }\end{array}$ \\
\hline & & Decision: done \\
\hline \multirow[t]{2}{*}{$\begin{array}{l}\text { Blinding? } \\
\text { All outcomes }\end{array}$} & Low risk & $\begin{array}{l}\text { Quote: "The drugs were dispensed in coded envelopes. The investigators and } \\
\text { the patients were thus blinded to which drug was being given to which patient. } \\
\text { The radiologist responsible for reading the X-rays was also blinded to the drug } \\
\text { therapy" }\end{array}$ \\
\hline & & Decision: done \\
\hline $\begin{array}{l}\text { Incomplete outcome data } \\
\text { addressed? } \\
\text { All outcomes }\end{array}$ & Low risk & $\begin{array}{l}72 \text { participants were randomized; all } 72 \text { were followed up for seizure recur- } \\
\text { rence at } 6 \text { months (100\%) }\end{array}$ \\
\hline $\begin{array}{l}\text { Free of selective report- } \\
\text { ing? }\end{array}$ & Low risk & No evidence of selective reporting \\
\hline Free of other bias? & Low risk & No evidence of other bias \\
\hline
\end{tabular}

Gongora-Rivera 2006

$\begin{array}{ll}\text { Methods } & \text { Randomized controlled trial } \\ & \text { Duration: between November } 1999 \text { and January } 2001\end{array}$

Participants Number: 36 enrolled (14 male, 22 female)

Inclusion criteria: adults with subarachnoid and intraventricular cysticercosis

Exclusion criteria: concurrent disease that contraindicated corticosteroid, albendazole allergy, previous cysticidal or surgical treatment for neurocysticercosis in the previous 3 months, pregnant or lactating women, neurological diseases affecting function, unable to attend for regular follow up, Karnofsky score $\leq 50$ points

Type of lesion: degenerating, viable, or mixed

\begin{tabular}{ll}
\hline Interventions & Group 1. Intravenous dexamethasone: $8 \mathrm{mg}$ every 8 hours for 4 days followed by 15 mg per kg albenda- \\
zole for 1 day \\
Group 2. Intravenous dexamethasone: $8 \mathrm{mg}$ every 8 hours for 4 days followed by $30 \mathrm{mg}$ per kg albenda- \\
zole for 1 day
\end{tabular}


Gongora-Rivera 2006 (Continued)
Notes
Location: Mexico
Source of funding: not stated

\section{Risk of bias}

\begin{tabular}{|c|c|c|}
\hline Bias & Authors' judgement & Support for judgement \\
\hline $\begin{array}{l}\text { Adequate sequence gener- } \\
\text { ation? }\end{array}$ & Low risk & $\begin{array}{l}\text { Quote: "...a computer-generated randomization plan" } \\
\text { Decision: done }\end{array}$ \\
\hline Allocation concealment? & Low risk & $\begin{array}{l}\text { Quote: "The code of the two different albendazole doses was available in } \\
\text { sealed envelopes and was not opened until the trial completion" }\end{array}$ \\
\hline $\begin{array}{l}\text { Blinding? } \\
\text { All outcomes }\end{array}$ & Low risk & $\begin{array}{l}\text { Quote: "For blinding the pharmaceutical laboratory...provided according to a } \\
\text { computer-generated randomization plan, tablets containing } 200 \mathrm{mg} \text { or } 400 \mathrm{mg} \\
\text { albendazole with identical appearance. Neither the patient nor the study staff } \\
\text { were aware of treatment assignment" } \\
\text { Decision: done }\end{array}$ \\
\hline $\begin{array}{l}\text { Incomplete outcome data } \\
\text { addressed? } \\
\text { All outcomes }\end{array}$ & Low risk & $\begin{array}{l}\text { Inclusion of randomized participants in the analysis: } 36 \text { randomized, } 5 \text { did not } \\
\text { compete the study ( } 86 \%) \text {. An intention-to-treat analysis was also undertaken } \\
\text { with similar results obtained. }\end{array}$ \\
\hline $\begin{array}{l}\text { Free of selective report- } \\
\text { ing? }\end{array}$ & Low risk & No evidence of selective reporting \\
\hline Free of other bias? & Low risk & No evidence of other bias \\
\hline
\end{tabular}

\section{Kalra 2003}

\begin{tabular}{ll}
\hline Methods & Randomized controlled trial \\
& Duration: dates not specified. Participants followed up for 6 months.
\end{tabular}

Pumber: 123 enrolled (65 male, 58 female)
Inclusion criteria: children aged 1 to 14 years with seizures plus 1 or 2 ring-enhancing lesions, excludin
intraventricular cysts
Exclusion criteria: suspected tuberculosis, intraocular cysts, multiple lesions, disk or calcified lesions,
intraventricular cysts, or hydrocephalus
Type of lesion: non-viable

Interventions Group 1. Dexamethasone: $0.15 \mathrm{mg}$ per kg bodyweight per day for 5 days plus $15 \mathrm{mg}$ per kg albendazole for 28 days starting on day 3

Group 2. No dexamethasone or albendazole

Outcomes Included in review: persistence of lesions at 3 months; complete or partial resolution or calcification of lesions at 3 months; seizure recurrence at 3 and 6 months

Lotes $\quad$ Location: India
Source of funding: not stated


Kalra 2003 (Continued)

\section{Risk of bias}

\begin{tabular}{|c|c|c|}
\hline Bias & Authors' judgement & Support for judgement \\
\hline $\begin{array}{l}\text { Adequate sequence gener- } \\
\text { ation? }\end{array}$ & Low risk & $\begin{array}{l}\text { Quote: "A simple randomization scheme was used for allocation of patients to } \\
\text { the treated or control groups" } \\
\text { Decision: done }\end{array}$ \\
\hline Allocation concealment? & Low risk & $\begin{array}{l}\text { Quote: "Random assignment code was concealed up to the time of allocation } \\
\text { in sealed envelopes labelled with a unique patient number" } \\
\text { Decision: done }\end{array}$ \\
\hline $\begin{array}{l}\text { Blinding? } \\
\text { All outcomes }\end{array}$ & High risk & $\begin{array}{l}\text { Quote: "Evaluation of CT lesions...was performed by a single radiologist blind- } \\
\text { ed to the treatment assignment and to the clinic outcome" } \\
\text { Blinding of participants was not described, and placebos were not used. Ab- } \\
\text { stract refers to an "open trial". } \\
\text { Decision: partially done, for radiological outcomes only }\end{array}$ \\
\hline $\begin{array}{l}\text { Incomplete outcome data } \\
\text { addressed? } \\
\text { All outcomes }\end{array}$ & High risk & $\begin{array}{l}123 \text { participants randomized, } 30 \text { lost to follow up at } 3 \text { months }(93 / 123=76 \%) \text {. } \\
\text { No discussion of the difference between participants available for follow up } \\
\text { and those lost to follow up. }\end{array}$ \\
\hline $\begin{array}{l}\text { Free of selective report- } \\
\text { ing? }\end{array}$ & Low risk & No evidence of selective reporting \\
\hline Free of other bias? & Low risk & No evidence of other bias \\
\hline
\end{tabular}

Kaur 2009

Methods Randomized controlled trial

Duration: participants enrolled January to December 2007 and followed up for 6 months

Participants Number: 112 enrolled (69 male, 43 female), 103 included in the analysis

Inclusion criteria: children aged 1 to 13 years with focal or generalized seizures for less than 3 months, no neuro deficits on clinical examination, and characteristic neuroimaging findings of single, small (< $20 \mathrm{~mm}$ ) well-defined lesion with peripheral (ring) or uniform (disc) contrast enhancement with or without surrounding oedema, with minimal or no mass effect, without any midline shift

Exclusion criteria: multiple lesions, extra parenchymal neurocysticercosis, focal neurologic deficit, suspected tuberculosis, any active systemic disease, or history of prior antiparasitic treatment

Category of lesion: degenerating

Interventions Group 1: Albendazole $15 \mathrm{mg}$ per kg bodyweight per day for 7 days, oral prednisolone 2 mg per kg per day for 5 days, plus 75 mg per kg praziquantel for 1 day

Group 2: Albendazole $15 \mathrm{mg}$ per kg bodyweight per day for 7 days, oral prednisolone $2 \mathrm{mg}$ per $\mathrm{kg}$ per day for 5 days, plus $75 \mathrm{mg}$ per kg placebo for 1 day

\section{Outcomes}

Included in the review: complete resolution of lesion at 1, 3, and 6 months, recurrence of seizures within 6 months, adverse effects of therapy 
Kaur 2009 (Continued)
Notes
Location: India
Source of funding: not stated

\section{Risk of bias}

\begin{tabular}{|c|c|c|}
\hline Bias & Authors' judgement & Support for judgement \\
\hline $\begin{array}{l}\text { Adequate sequence gener- } \\
\text { ation? }\end{array}$ & Unclear risk & $\begin{array}{l}\text { Quote: "All children were randomized and allocated to either of these two } \\
\text { groups using a table of random numbers" } \\
\text { Decision: done }\end{array}$ \\
\hline Allocation concealment? & Low risk & $\begin{array}{l}\text { Quote: "Identical looking sachets in strengths of } 50,100 \text {, and } 200 \mathrm{mg} \text { of prazi- } \\
\text { quantel and placebo were prepared...these sachets were coded as group A and } \\
\text { B. The code was kept secret and opened only after completion of the study" } \\
\text { Decision: done }\end{array}$ \\
\hline $\begin{array}{l}\text { Blinding? } \\
\text { All outcomes }\end{array}$ & Low risk & $\begin{array}{l}\text { Quote: "All persons involved in the study including the patient, the clinical in- } \\
\text { vestigator and the neuroradiologist were blinded to the random allocation" } \\
\text { Decision: done }\end{array}$ \\
\hline $\begin{array}{l}\text { Incomplete outcome data } \\
\text { addressed? } \\
\text { All outcomes }\end{array}$ & Low risk & $\begin{array}{l}112 \text { children were enrolled, } 9 \text { did not report for follow up, so } 103 \text { included in } \\
\text { the main analysis }(92 \%)\end{array}$ \\
\hline $\begin{array}{l}\text { Free of selective report- } \\
\text { ing? }\end{array}$ & Low risk & No evidence of selective reporting \\
\hline Free of other bias? & Low risk & No evidence of other bias \\
\hline
\end{tabular}

\section{Padma 1994}

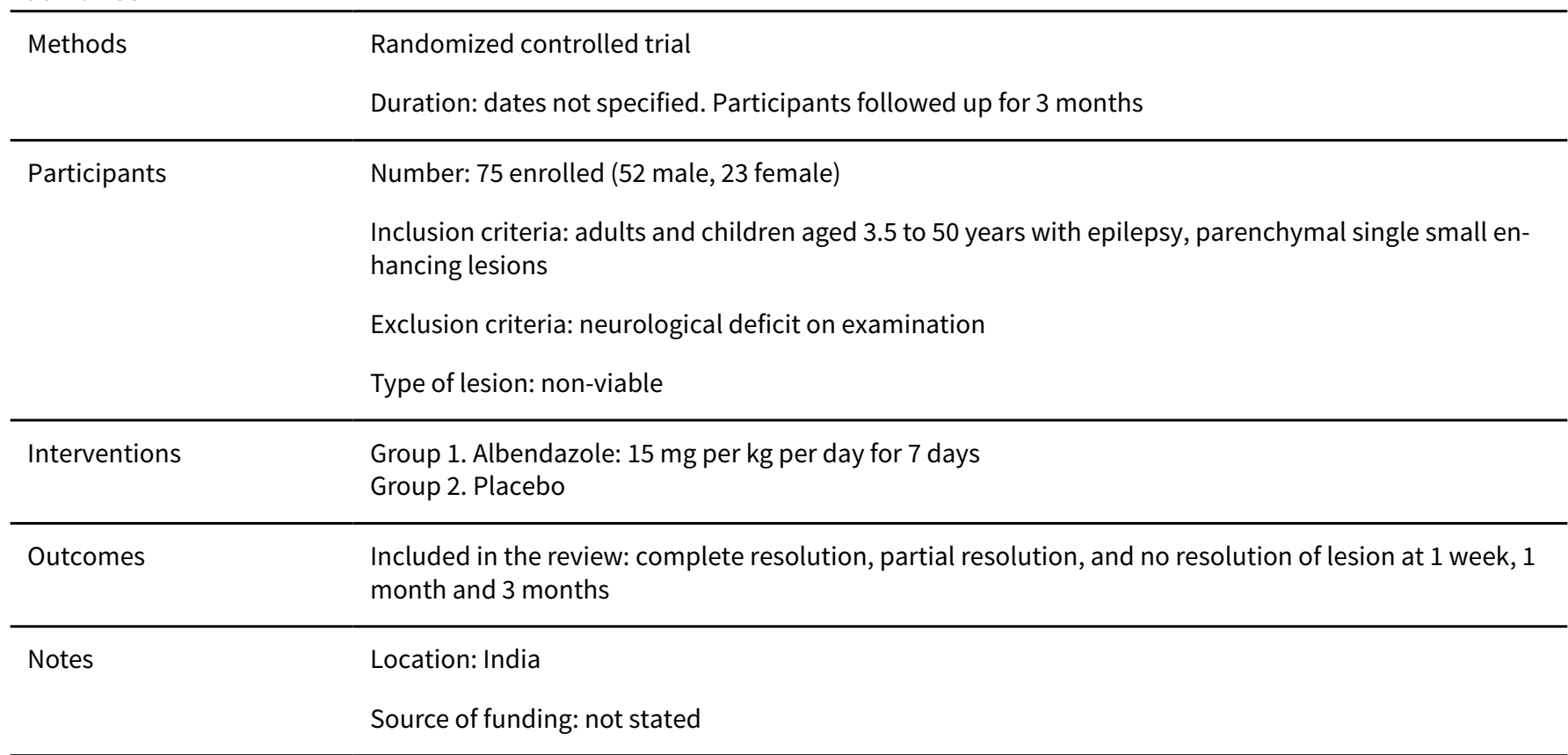


Padma 1994 (Continued)

Risk of bias

\begin{tabular}{|c|c|c|}
\hline Bias & Authors' judgement & Support for judgement \\
\hline $\begin{array}{l}\text { Adequate sequence gener- } \\
\text { ation? }\end{array}$ & Unclear risk & $\begin{array}{l}\text { Quote: "Patients were randomly allocated to placebo or albendazole therapy" } \\
\text { Decision: unclear, probably done }\end{array}$ \\
\hline Allocation concealment? & Unclear risk & $\begin{array}{l}\text { Not described } \\
\text { Decision: unclear }\end{array}$ \\
\hline $\begin{array}{l}\text { Blinding? } \\
\text { All outcomes }\end{array}$ & Low risk & $\begin{array}{l}\text { Quote: "CTs were assessed by a neuroradiologist who was not aware of the } \\
\text { treatment received by the patient" } \\
\text { Placebos were used for participants } \\
\text { Decision: done }\end{array}$ \\
\hline $\begin{array}{l}\text { Incomplete outcome data } \\
\text { addressed? } \\
\text { All outcomes }\end{array}$ & Low risk & 75 participants randomized, follow-up data at 3 months available for 68 (91\%) \\
\hline $\begin{array}{l}\text { Free of selective report- } \\
\text { ing? }\end{array}$ & Low risk & No evidence of selective reporting \\
\hline Free of other bias? & Low risk & No evidence of other bias \\
\hline
\end{tabular}

Padma 1995

Methods Randomized controlled trial

Duration: dates not specified. Participants followed up for 3 months.

\begin{tabular}{|c|c|}
\hline \multirow[t]{4}{*}{ Participants } & Number: 29 enrolled (22 male, 7 female) \\
\hline & $\begin{array}{l}\text { Inclusion criteria: adults and children aged } 8 \text { to } 50 \text { with multiple cystic lesions suggestive of neurocys- } \\
\text { ticercosis plus neurological signs }\end{array}$ \\
\hline & Exclusion criteria: calcified lesions only \\
\hline & $\begin{array}{l}\text { Type of lesion: degenerating, viable or mixed (possible to follow the radiological clearance of individual } \\
\text { lesions by type) }\end{array}$ \\
\hline Interventions & $\begin{array}{l}\text { Group 1. Albendazole: } 15 \mathrm{mg} \text { per kg per day for } 7 \text { days } \\
\text { Group 2. Placebo }\end{array}$ \\
\hline \multirow[t]{2}{*}{ Outcomes } & $\begin{array}{l}\text { Included in the review: change in number of lesions at } 1 \text { and } 3 \text { months; persistence of lesions at } 1 \text { week, } \\
1 \text { month, and } 3 \text { months }\end{array}$ \\
\hline & Not included in the review: change in oedema at 1 and 3 months \\
\hline \multirow[t]{2}{*}{ Notes } & Location: India \\
\hline & Source of funding: not stated \\
\hline
\end{tabular}

\section{Risk of bias}


Padma 1995 (Continued)

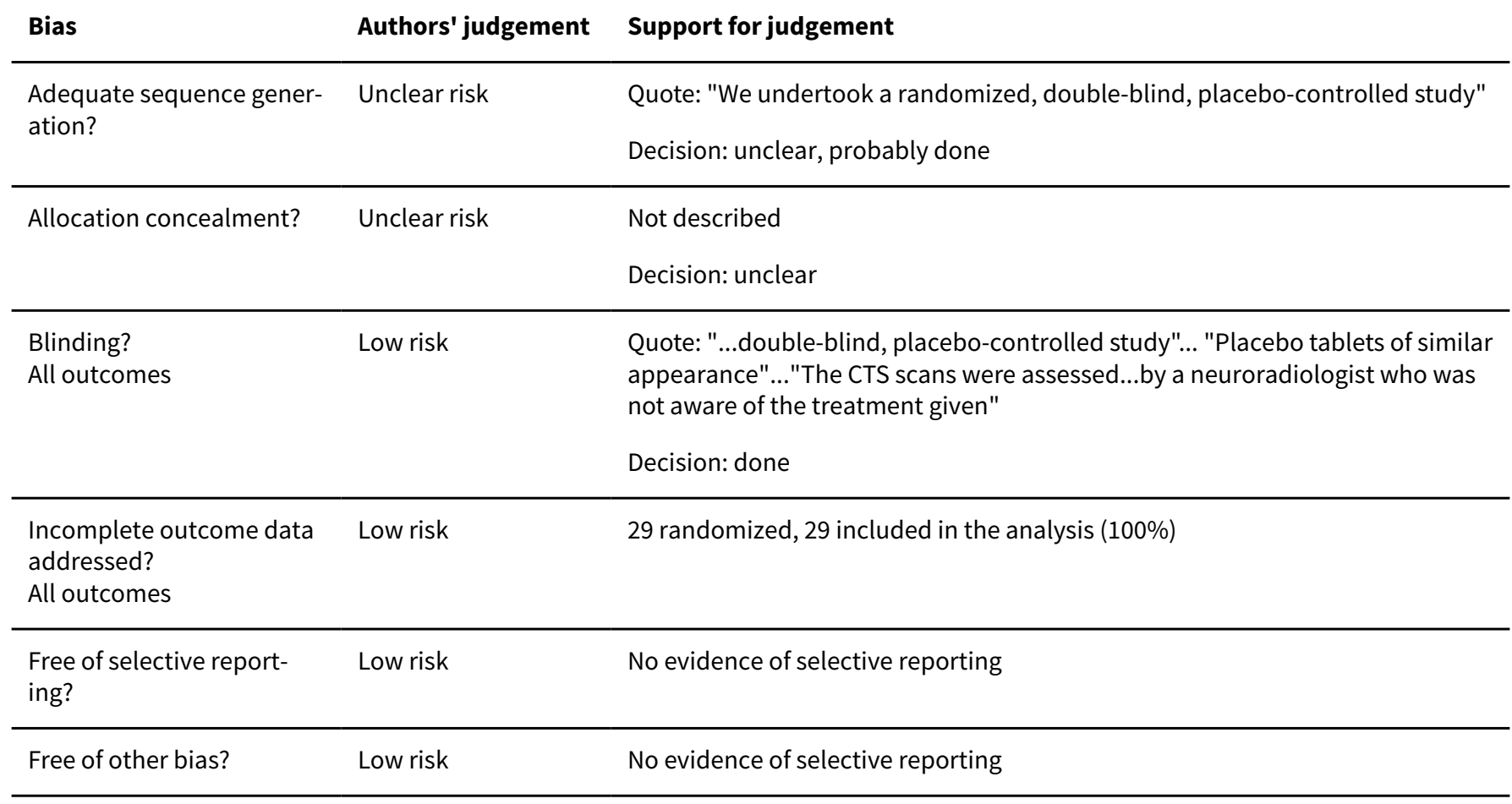

Singhi 2000

$\begin{array}{ll}\text { Methods } & \text { Randomized controlled trial } \\ \text { Duration: recruitment from } 1994 \text { to 1998. Participants followed up for } 6 \text { months. }\end{array}$

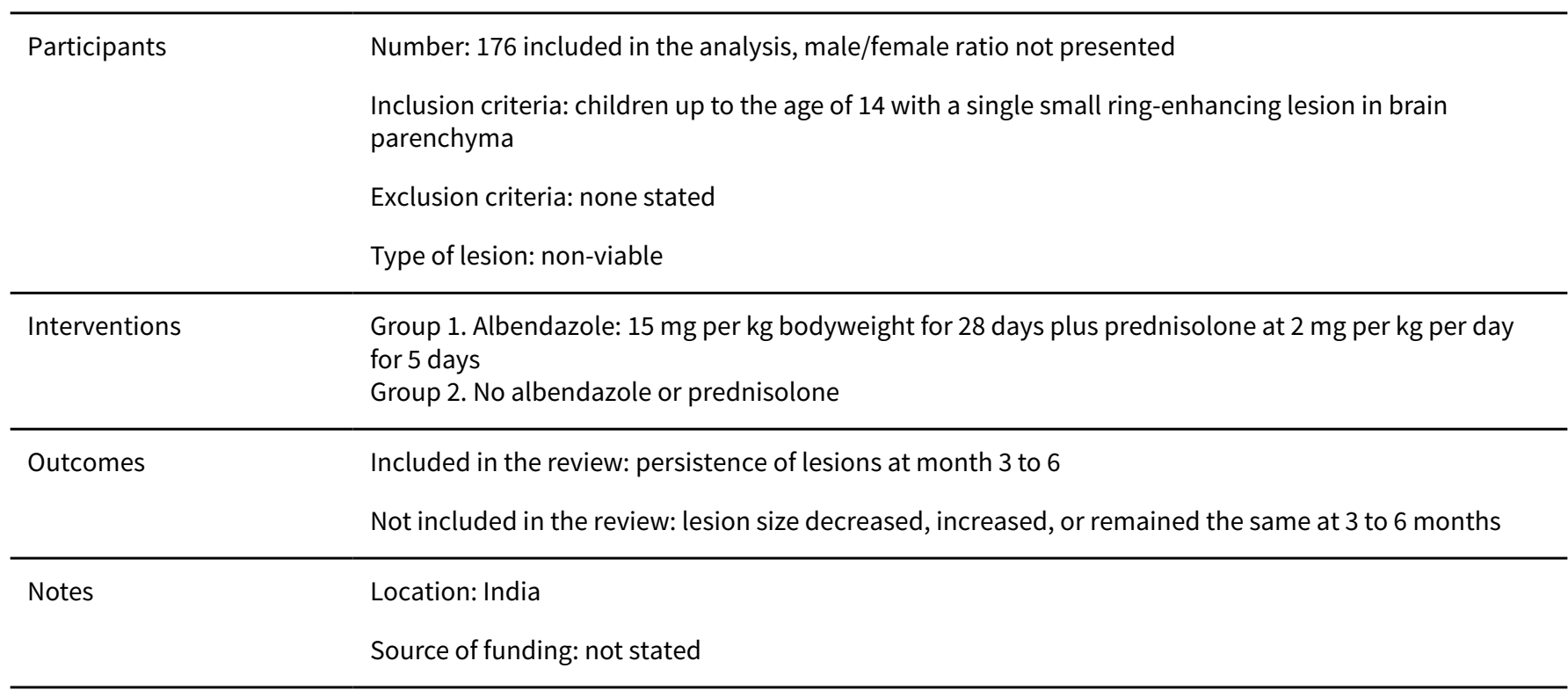

\section{Risk of bias}

\begin{tabular}{lll}
\hline Bias & Authors' judgement & Support for judgement \\
\hline $\begin{array}{ll}\text { Adequate sequence gener- } \\
\text { ation? }\end{array}$ & Unclear risk & $\begin{array}{l}\text { Quote: "Children..were chosen at random to receive either albendazole thera- } \\
\text { py or no specific anticysticeral therapy"..."randomly allocated children" }\end{array}$ \\
\hline
\end{tabular}


Singhi 2000 (Continued)

Decision: unclear, probably done

\begin{tabular}{|c|c|c|}
\hline Allocation concealment? & Unclear risk & $\begin{array}{l}\text { No described } \\
\text { Decision: unclear }\end{array}$ \\
\hline $\begin{array}{l}\text { Blinding? } \\
\text { All outcomes }\end{array}$ & Unclear risk & $\begin{array}{l}\text { Not described. Placebos not used. } \\
\text { Decision: unclear, probably not done. }\end{array}$ \\
\hline $\begin{array}{l}\text { Incomplete outcome data } \\
\text { addressed? } \\
\text { All outcomes }\end{array}$ & Unclear risk & $\begin{array}{l}\text { Not clear how many participants enrolled and randomized, outcomes data } \\
\text { presented for } 176\end{array}$ \\
\hline $\begin{array}{l}\text { Free of selective report- } \\
\text { ing? }\end{array}$ & Low risk & No evidence of selective reporting \\
\hline Free of other bias? & Low risk & No evidence of other bias \\
\hline
\end{tabular}

\section{Singhi 2003}

$\begin{array}{ll}\text { Methods } & \text { Randomized controlled trial } \\ \text { Duration: recruitment from June } 1999 \text { to June 2000. Participants were followed up for } 12 \text { months. }\end{array}$

Number: 147 randomized, 122 included in the analysis (68 male, 54 female)
Inclusion criteria: children with seizures for less than 3 months and up to 3 small enhancing lesions in
parenchyma
Exclusion criteria: raised intracranial pressure, focal neurological deficit, neurodevelopmental delay,
any chronic systemic disease, other lesions on imaging, evidence of tuberculosis
Type of lesion: non-viable

Interventions

Group 1. Oral prednisolone: $2 \mathrm{mg}$ per $\mathrm{kg}$ once daily for 5 days plus $15 \mathrm{mg}$ per $\mathrm{kg}$ per day albendazole for 4 weeks starting 2 days after prednisolone started

Group 2. Oral prednisolone: $2 \mathrm{mg}$ per kg once daily for 5 days plus $15 \mathrm{mg}$ per $\mathrm{kg}$ per day albendazole for 1 week starting 2 days after prednisolone started

Outcomes Included in the review: persistence of lesions at 1 month; recurrence of seizures within 12 months; epi-
gastric discomfort with treatment

Not included in the review: lesion size reduced at 6 months

\begin{tabular}{ll}
\hline Notes & Location: India \\
& Source of funding: not stated \\
\hline
\end{tabular}

\section{Risk of bias}

\begin{tabular}{lll}
\hline Bias & Authors' judgement & Support for judgement \\
\hline $\begin{array}{ll}\text { Adequate sequence gener- } \\
\text { ation? }\end{array}$ & Low risk & Quote: "...they were randomized according to random number tables..." \\
& & Decision: done \\
\hline Allocation concealment? & Unclear risk & Not described \\
\hline
\end{tabular}


Singhi 2003 (Continued)

Decision: unclear

\begin{tabular}{|c|c|c|}
\hline $\begin{array}{l}\text { Blinding? } \\
\text { All outcomes }\end{array}$ & Low risk & $\begin{array}{l}\text { Quote: "None of the persons involved in the study (i.e. patient, investigators } \\
\text { and neuroradiologist) was aware of this random allocation. The code was } \\
\text { opened only after completion of the study" } \\
\text { Decision: done }\end{array}$ \\
\hline $\begin{array}{l}\text { Incomplete outcome data } \\
\text { addressed? } \\
\text { All outcomes }\end{array}$ & High risk & $\begin{array}{l}147 \text { randomized, } 25 \text { excluded due to poor compliance with treatment or inad- } \\
\text { equate follow up ( } 83 \% \text { included in the analysis). No discussion of the differ- } \\
\text { ences between participants included in the analysis and those excluded. }\end{array}$ \\
\hline $\begin{array}{l}\text { Free of selective report- } \\
\text { ing? }\end{array}$ & Low risk & No evidence of selective reporting \\
\hline Free of other bias? & Low risk & No evidence of other bias \\
\hline
\end{tabular}

\section{Singhi 2004}

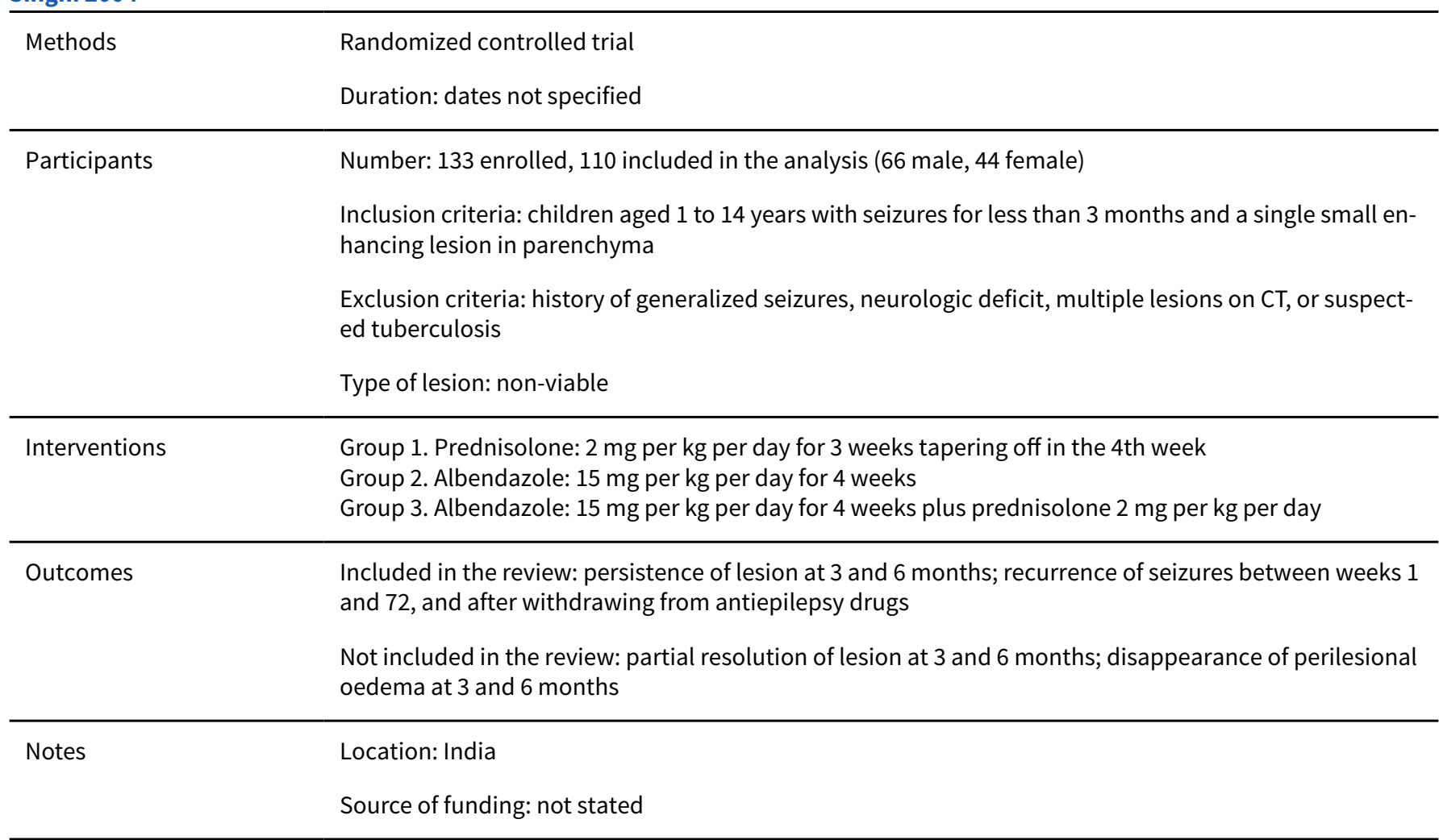

\section{Risk of bias}

\begin{tabular}{lll}
\hline Bias & Authors' judgement & Support for judgement \\
\hline $\begin{array}{l}\text { Adequate sequence gener- } \\
\text { ation? }\end{array}$ & Low risk & Quote: "The children were randomly assigned...using random number tables" \\
& & Decision: done \\
\hline Allocation concealment? & Unclear risk & Not described \\
& & Decision: unclear \\
\hline
\end{tabular}


Singhi 2004 (Continued)

\begin{tabular}{|c|c|c|}
\hline \multirow[t]{3}{*}{$\begin{array}{l}\text { Blinding? } \\
\text { All outcomes }\end{array}$} & Unclear risk & $\begin{array}{l}\text { Quote: "All CT scans were assessed by a neuroradiologist who was blinded to } \\
\text { treatment assignment and to clinical outcome" }\end{array}$ \\
\hline & & Blinding not described for participants \\
\hline & & Decision: unclear, partially done for radiological outcomes \\
\hline $\begin{array}{l}\text { Incomplete outcome data } \\
\text { addressed? } \\
\text { All outcomes }\end{array}$ & Low risk & $\begin{array}{l}133 \text { participants were randomized, } 23 \text { lost to follow up ( } 85 \% \text { included in the } \\
\text { analysis) }\end{array}$ \\
\hline
\end{tabular}

\begin{tabular}{lll}
\hline $\begin{array}{l}\text { Free of selective report- } \\
\text { ing? }\end{array}$ & Low risk & No evidence of selective reporting \\
\hline Free of other bias? & Low risk & No evidence of other bias \\
\hline
\end{tabular}

Sotelo 1988

$\begin{array}{ll}\text { Methods } & \text { Randomized controlled trial } \\ \text { Duration: dates not specified. Participants were followed up for } 4 \text { months. }\end{array}$

\begin{tabular}{ll}
\hline Participants & Number: 25 enrolled (16 male, 9 female) \\
& Inclusion criteria: adults with parenchymal brain cysticercosis \\
& Exclusion criteria: none stated \\
& Type of lesion: viable \\
\hline Interventions & Group 1. Albendazole: 15 mg per kg per day for 1 month (no steroids) \\
& Group 2. Praziquantel: 50 mg per kg per day for 2 weeks (no steroids) \\
\hline Outcomes & $\begin{array}{l}\text { Included in the review: persistence of cysts at } 3 \text { to } 4 \text { months; number of cysts at baseline and } 3 \text { to } 4 \\
\text { months; resolution of symptoms at } 3 \text { to } 4 \text { months; adverse events associated with treatment }\end{array}$ \\
\hline Notes & Location: Mexico \\
Source of funding: not stated
\end{tabular}

\section{Risk of bias}

\begin{tabular}{lll}
\hline Bias & Authors' judgement & Support for judgement \\
\hline $\begin{array}{l}\text { Adequate sequence gener- } \\
\text { ation? }\end{array}$ & Unclear risk & Quote: "Patients were randomly allocated in three groups..." \\
& & Decision: unclear, probably done \\
\hline Allocation concealment? & Unclear risk & Not described \\
& & Decision: unclear \\
\hline $\begin{array}{l}\text { Blinding? } \\
\text { All outcomes }\end{array}$ & Unclear risk & Not described. Placebos not used. \\
& & Decision: unclear, probably not done \\
\hline
\end{tabular}


Sotelo 1988 (Continued)

Incomplete outcome data Low risk 25 participants enrolled and randomized, 25 included in the analysis (100\%)
addressed?

All outcomes

\begin{tabular}{lll}
\hline $\begin{array}{l}\text { Free of selective report- } \\
\text { ing? }\end{array}$ & Low risk & No evidence of selective reporting \\
\hline Free of other bias? & Low risk & No evidence of other bias \\
\hline
\end{tabular}

Sotelo 1990

$\begin{array}{ll}\text { Methods } & \text { Randomized controlled trial } \\ & \text { Duration: dates not stated. Participants followed up for } 3 \text { months }\end{array}$

\begin{tabular}{ll}
\hline Participants & Number: 114 enrolled ( 67 male, 47 female) \\
& \begin{tabular}{l} 
Inclusion criteria: adults and children aged 7 to 72 years with parenchymal brain cysts without CT evi- \\
dence of surrounding inflammation \\
Exclusion criteria: any parenchymal cysticerci surrounded by oedema or showing enhancement after \\
contrast medium administration \\
Type of lesion: viable \\
\hline \begin{tabular}{l} 
Group 1. Praziquantel: 50 mg per kg bodyweight for 15 days \\
Group 2. Praziquantel: 50 mg per kg bodyweight for 8 days \\
Group 3. Albendazole: 15 mg per kg bodyweight for 30 days \\
Group 4. Albendazole: 15 mg per kg bodyweight for 8 days \\
\hline Included in the review: mean number of cysts before and 3 months after treatment; persistence of le- \\
sions after 3 months; over $50 \%$ lesions disappeared after 3 months; no resolution after 3 months; ad- \\
verse events associated with treatment, adverse events severe enough to need steroids; persistence of \\
symptoms after 3 months; improvement in signs and symptoms after 3 months
\end{tabular} \\
\hline Location: Mexico \\
Source of funding: supported by the Secretaria de Salud de Mexico
\end{tabular} \\
\hline Notes
\end{tabular}

\section{Risk of bias}

\begin{tabular}{lll}
\hline Bias & Authors' judgement & Support for judgement \\
\hline $\begin{array}{l}\text { Adequate sequence gener- } \\
\text { ation? }\end{array}$ & Unclear risk & $\begin{array}{l}\text { Quote: "...patients were randomly allocated to one of four treatment groups" } \\
\text { Decision: unclear, probably done }\end{array}$ \\
\hline Allocation concealment? & Unclear risk & Not described \\
& Decision: unclear \\
\hline $\begin{array}{l}\text { Blinding? } \\
\text { All outcomes }\end{array}$ & Unclear risk & $\begin{array}{l}\text { Quote: "Evaluation of all CT studies was done at the end of the trial by two } \\
\text { groups of clinicians and radiologists who were not aware of the treatment } \\
\text { group to which the patients had been allocated" }\end{array}$ \\
& Blinding not described for participants, and placebos not used \\
& Decision: unclear, partially done for radiological outcomes \\
\hline \hline
\end{tabular}


Sotelo 1990 (Continued)

$\begin{array}{ll}\text { Incomplete outcome data } & \text { Low risk } \\ \text { addressed? } & \text { for all } 114(100 \%) \\ \text { All outcomes } & \end{array}$

\begin{tabular}{lll}
\hline $\begin{array}{l}\text { Free of selective report- } \\
\text { ing? }\end{array}$ & Low risk & No evidence of selective reporting \\
\hline Free of other bias? & Low risk & No evidence of other bias \\
\hline
\end{tabular}

Characteristics of excluded studies [ordered by study ID]

\begin{tabular}{ll}
\hline Study & Reason for exclusion \\
\hline Antoniuk 1991 & Groups not allocated on a random basis, but according to clinical differences \\
\hline Bustos 2006 & No control group \\
\hline Carpio 1995 & Quasi-randomized \\
\hline Lopez-Gomez 2001 & Comparisons did not meet the inclusion criteria \\
\hline Marquez-Caraveo 2004 & No control group \\
\hline Medina 1993 & Unclear whether groups were randomized; unable to contact the author for clarification \\
\hline Proano 2006 & No control group \\
\hline Sanchetee 1994 & No control group \\
\hline Thussu 2008 & Quasi-randomized \\
\hline
\end{tabular}

\section{Characteristics of studies awaiting assessment [ordered by study ID]}

Cruz 1991

$\begin{array}{ll}\text { Methods } & \text { Randomized or quasi-randomized controlled trial } \\ \text { Duration: dates not supplied. Participants followed up for } 3 \text { months }\end{array}$

\begin{tabular}{ll}
\hline Participants & Number: 100 enrolled (45 male, 55 female) \\
Inclusion criteria: adults with diagnosed cerebral cysticercosis - any developmental stage of the \\
parasite, localization parenchymous, subarachnoid, or ventricular \\
Exclusion criteria: none stated \\
Type of lesion: embryonal, encephalitic, cystic, calcified, or mixed \\
\hline $\begin{array}{l}\text { Group } 1 . \text { Praziquantel: } 50 \mathrm{mg} / \mathrm{kg} \text { bodyweight daily for } 15 \text { days plus } 750 \mathrm{mg} \text { intravenous dexametha- } \\
\text { Sone over } 3 \text { days followed by oral prednisolone every } 3 \text { days until day } 45 \\
\text { Group } 2 . \text { Albendazole: } 15 \mathrm{mg} / \mathrm{kg} \text { for } 30 \text { days plus } 750 \mathrm{mg} \text { intravenous dexamethasone over } 3 \text { days } \\
\text { followed by oral prednisolone every } 3 \text { days until day } 45\end{array}$
\end{tabular}


Cruz 1991 (Continued)

Outcomes
Persistence of encephalitic lesions at 3 months; persistence of cysts at 3 months; No change, slight improvement, marked improvement, and freedom from headache at 3 months; no change, slight improvement, marked improvement, and freedom from seizures at 3 months; no change, slight improvement, marked improvement, and freedom from raised intracranial pressure at 3 months; no change, slight improvement, marked improvement, and freedom from miscellaneous signs at 3 months

Notes
Location: Ecuador
Source of funding: partially funded by SmithKline Beecham Pharmaceuticals

\section{Pretell 2000}

Methods Controlled clinical trial

Duration: dates not stated, 3 months follow up

Number: 26 (16 males, 10 females)
Inclusion criteria: single enhancing lesion in the brain parenchyma
Exclusion criteria: pregnancy, other intracranial pathology

Interventions $\quad$ Group 1: Praziquantel 3 doses $(25 \mathrm{mg} / \mathrm{kg})$ at 2-hour intervals for 1 day
Group 2: No antiparasitic therapy

\begin{tabular}{ll}
\hline Outcomes & Adverse effects of treatment, radiological resolution of lesions \\
\hline Notes & Location: Peru \\
& $\begin{array}{l}\text { Source of funding: the Food and Drug Administration; the Fogarty Foundation/NIH; NIAID/NIH } \\
\text { (USA) }\end{array}$
\end{tabular}

\section{Takayanagui 1992}

$\begin{array}{ll}\text { Methods } & \text { Controlled clinical trial } \\ & \text { Duration: dates not stated, follow up for } 6 \text { months }\end{array}$

\begin{tabular}{ll}
\hline Participants & Number: 59 \\
& Inclusion criteria: parenchymal non-enhancing cystic lesio \\
& Exclusion criteria: lesions with enhancement, encephalitic \\
\hline Interventions & $\begin{array}{l}\text { Group 1: Praziquantel daily doses } 50 \mathrm{mg} / \mathrm{kg} \text { for } 21 \text { days } \\
\text { Group 2: Albendazole daily doses } 20 \mathrm{mg} / \mathrm{kg} \text { for } 21 \text { days } \\
\text { Group 3: No antihelmintic }\end{array}$
\end{tabular}

Outcomes Number of cysts before and 6 months after treatment, adverse events

\begin{tabular}{ll}
\hline Notes & Location: Brazil \\
& Source of funding: not stated
\end{tabular}


Characteristics of ongoing studies [ordered by study ID]

Gilman 2007

\begin{tabular}{|c|c|}
\hline Trial name or title & Randomized study of albendazole in patients with epilepsy due to neurocysticercosis \\
\hline Methods & Randomized controlled trial \\
\hline \multirow[t]{3}{*}{ Participants } & Number expected: 120 \\
\hline & $\begin{array}{l}\text { Inclusion criteria: presence of taenia solium infection as demonstrated by serology and head CT, at } \\
\text { least } 2 \text { spontaneous seizures within the last } 6 \text { months, age } 16 \text { to } 65\end{array}$ \\
\hline & $\begin{array}{l}\text { Exclusion criteria: more than } 20 \text { cysts, prior therapy for cysticercosis, focal neurological or motor } \\
\text { deficits, cranial nerve lesions, history of epilepsy for over } 5 \text { years, CT head evidence of: arteriove- } \\
\text { nous malformations, trauma, cerebral infarcts, haemorrhages, focal disease not attributable to } \\
\text { cysticercosis, moderate or severe intracranial hypertension, status epilepticus }\end{array}$ \\
\hline Interventions & $\begin{array}{l}\text { Intervention: Albendazole and dexamethasone for } 10 \text { days } \\
\text { Control: Placebo for } 10 \text { days }\end{array}$ \\
\hline Outcomes & $\begin{array}{l}\text { Recurrence and number of seizures. Persistence and number of cysts. Participants are followed on } \\
\text { day } 15 \text { and 30, then every } 3 \text { months for } 3 \text { years. }\end{array}$ \\
\hline Starting date & May 2000 \\
\hline Contact information & Robert H Gilman, John Hopkins University, USA \\
\hline Study ID & NCT00004403 \\
\hline \multirow[t]{3}{*}{ Notes } & Location: USA \\
\hline & Registration number: NCT00004403 \\
\hline & Source of funding: FDA Office of Orphan Products Development \\
\hline
\end{tabular}

DATA AND ANALYSES

\section{Comparison 1. Albendazole vs placebo or no drug}

\begin{tabular}{lllll}
\hline Outcome or subgroup title & $\begin{array}{l}\text { No. of } \\
\text { studies }\end{array}$ & $\begin{array}{l}\text { No. of } \\
\text { partici- } \\
\text { pants }\end{array}$ & Statistical method & Effect size \\
\hline $\begin{array}{l}1 \text { Recurrence of seizures at trial's final } \\
\text { follow-up time }\end{array}$ & 6 & & Risk Ratio (M-H, Random, 95\% Cl) & Subtotals only \\
\hline $\begin{array}{l}1.1 \text { Viable lesions } \\
1.2 \text { Non-viable lesions }\end{array}$ & 1 & 116 & Risk Ratio (M-H, Random, 95\% Cl) & $0.89[0.60,1.32]$ \\
\hline $\begin{array}{l}1.3 \text { Mixed viable and non-viable le- } \\
\text { sions }\end{array}$ & 1 & 329 & Risk Ratio (M-H, Random, 95\% Cl) & $0.49[0.32,0.75]$ \\
\hline
\end{tabular}




\begin{tabular}{|c|c|c|c|c|}
\hline Outcome or subgroup title & $\begin{array}{l}\text { No. of } \\
\text { studies }\end{array}$ & $\begin{array}{l}\text { No. of } \\
\text { partici- } \\
\text { pants }\end{array}$ & Statistical method & Effect size \\
\hline $\begin{array}{l}2 \text { No successful withdrawal of anti- } \\
\text { convulsant drugs at follow up }\end{array}$ & 1 & & Risk Ratio (M-H, Fixed, 95\% Cl) & Totals not selected \\
\hline 2.1 Viable lesions & 1 & & Risk Ratio (M-H, Fixed, 95\% Cl) & $0.0[0.0,0.0]$ \\
\hline 3 All-cause death & 2 & 470 & Risk Ratio (M-H, Fixed, 95\% Cl) & $0.83[0.24,2.85]$ \\
\hline $\begin{array}{l}4 \text { Hospital admission, by follow-up } \\
\text { period }\end{array}$ & 1 & & Risk Ratio (M-H, Fixed, 95\% Cl) & Totals not selected \\
\hline 4.1 Start to 3 months & 1 & & Risk Ratio (M-H, Fixed, 95\% Cl) & $0.0[0.0,0.0]$ \\
\hline 4.23 to 6 months & 1 & & Risk Ratio (M-H, Fixed, 95\% Cl) & $0.0[0.0,0.0]$ \\
\hline 4.36 to 12 months & 1 & & Risk Ratio (M-H, Fixed, 95\% Cl) & $0.0[0.0,0.0]$ \\
\hline 4.41 to 2 years & 1 & & Risk Ratio (M-H, Fixed, 95\% Cl) & $0.0[0.0,0.0]$ \\
\hline 4.52 to 3 years & 1 & & Risk Ratio (M-H, Fixed, 95\% Cl) & $0.0[0.0,0.0]$ \\
\hline 4.63 to 4 years & 1 & & Risk Ratio (M-H, Fixed, 95\% Cl) & $0.0[0.0,0.0]$ \\
\hline $\begin{array}{l}5 \text { Symptoms not resolved after } 3 \\
\text { months }\end{array}$ & 1 & & Risk Ratio (M-H, Fixed, 95\% Cl) & Totals not selected \\
\hline $\begin{array}{l}6 \text { Symptoms of encephalopathy } \\
\text { (headache, vomiting, or altered sen- } \\
\text { sorium), by period of follow up }\end{array}$ & 1 & & Risk Ratio (M-H, Fixed, 95\% Cl) & Totals not selected \\
\hline 6.1 Start to 3 months & 1 & & Risk Ratio (M-H, Fixed, 95\% Cl) & $0.0[0.0,0.0]$ \\
\hline 6.23 to 6 months & 1 & & Risk Ratio (M-H, Fixed, 95\% Cl) & $0.0[0.0,0.0]$ \\
\hline 6.36 to 12 months & 1 & & Risk Ratio (M-H, Fixed, 95\% Cl) & $0.0[0.0,0.0]$ \\
\hline 6.41 to 2 years & 1 & & Risk Ratio (M-H, Fixed, 95\% Cl) & $0.0[0.0,0.0]$ \\
\hline 6.52 to 3 years & 1 & & Risk Ratio (M-H, Fixed, 95\% Cl) & $0.0[0.0,0.0]$ \\
\hline 6.63 to 4 years & 1 & & Risk Ratio (M-H, Fixed, 95\% Cl) & $0.0[0.0,0.0]$ \\
\hline $\begin{array}{l}7 \text { Persistence of lesions at trial's final } \\
\text { follow-up time (up to } 12 \text { months) }\end{array}$ & 9 & & Risk Ratio (M-H, Fixed, 95\% Cl) & Subtotals only \\
\hline 7.1 Viable lesions & 2 & 192 & Risk Ratio (M-H, Fixed, 95\% Cl) & $0.56[0.45,0.70]$ \\
\hline 7.2 Non-viable lesions & 6 & 570 & Risk Ratio (M-H, Fixed, 95\% Cl) & $0.98[0.86,1.11]$ \\
\hline $\begin{array}{l}7.3 \text { Mixed viable and non-viable le- } \\
\text { sions }\end{array}$ & 1 & 298 & Risk Ratio (M-H, Fixed, 95\% Cl) & $1.01[0.97,1.06]$ \\
\hline 8 Headache during treatment & 4 & 392 & Risk Ratio (M-H, Fixed, 95\% Cl) & $1.37[1.08,1.73]$ \\
\hline
\end{tabular}




\begin{tabular}{|c|c|c|c|c|}
\hline Outcome or subgroup title & $\begin{array}{l}\text { No. of } \\
\text { studies }\end{array}$ & $\begin{array}{l}\text { No. of } \\
\text { partici- } \\
\text { pants }\end{array}$ & Statistical method & Effect size \\
\hline 8.1 Viable lesions & 2 & 139 & Risk Ratio (M-H, Fixed, 95\% Cl) & $2.96[0.49,17.77]$ \\
\hline 8.2 Non-viable lesions & 1 & 83 & Risk Ratio (M-H, Fixed, 95\% Cl) & $15.82[0.98,255.96]$ \\
\hline $\begin{array}{l}8.3 \text { Mixed viable and non-viable le- } \\
\text { sions }\end{array}$ & 1 & 170 & Risk Ratio (M-H, Fixed, 95\% Cl) & $1.14[0.92,1.42]$ \\
\hline $\begin{array}{l}9 \text { Headache during treatment - by } \\
\text { corticosteroid use }\end{array}$ & 4 & & Risk Ratio (M-H, Fixed, 95\% Cl) & Subtotals only \\
\hline $\begin{array}{l}\text { 9.1 Corticosteroids given with alben- } \\
\text { dazole }\end{array}$ & 2 & 286 & Risk Ratio (M-H, Fixed, 95\% Cl) & $1.16[0.93,1.44]$ \\
\hline 9.2 No corticosteroids given & 2 & 106 & Risk Ratio (M-H, Fixed, 95\% Cl) & $9.49[1.40,64.45]$ \\
\hline 10 Dizziness during treatment & 3 & 222 & Risk Ratio (M-H, Fixed, 95\% Cl) & $3.77[1.42,9.97]$ \\
\hline $\begin{array}{l}11 \text { Nausea, vomiting, or abdominal } \\
\text { pain during treatment }\end{array}$ & 4 & 392 & Risk Ratio (M-H, Fixed, 95\% Cl) & $1.40[1.01,1.94]$ \\
\hline 12 Seizures during treatment & 5 & 455 & Risk Ratio (M-H, Fixed, 95\% Cl) & $1.62[0.79,3.31]$ \\
\hline
\end{tabular}

Analysis 1.1. Comparison 1 Albendazole vs placebo or no drug,
Outcome 1 Recurrence of seizures at trial's final follow-up time.

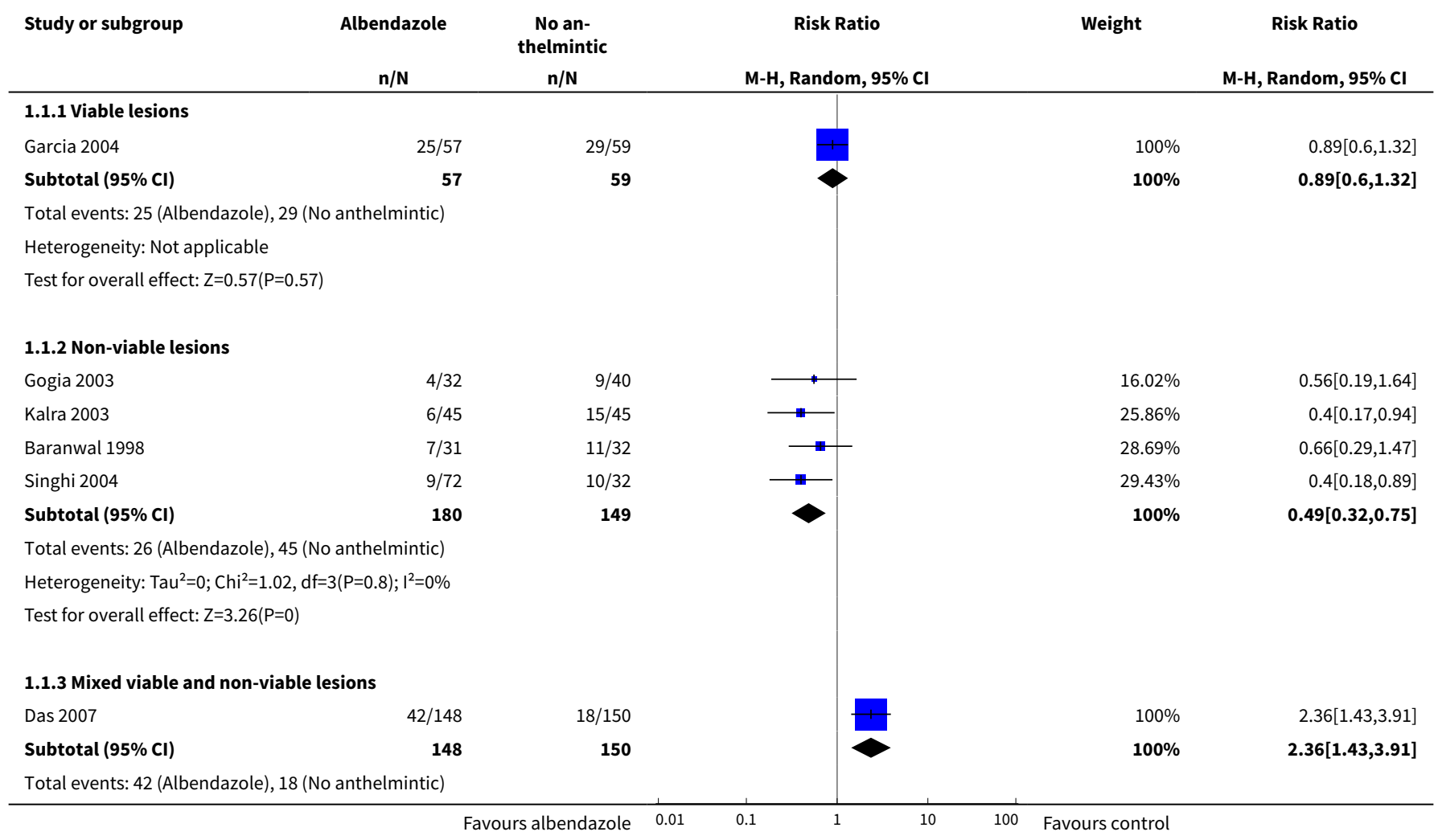




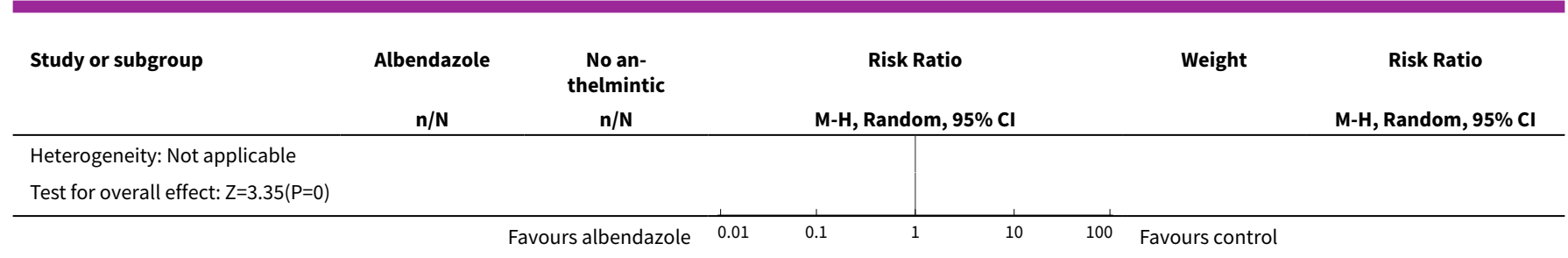

Analysis 1.2. Comparison 1 Albendazole vs placebo or no drug, Outcome 2 No successful withdrawal of anticonvulsant drugs at follow up.

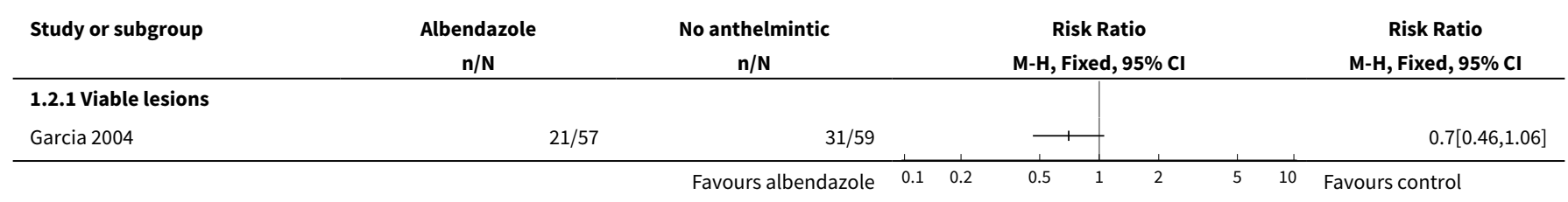

Analysis 1.3. Comparison 1 Albendazole vs placebo or no drug, Outcome 3 All-cause death.

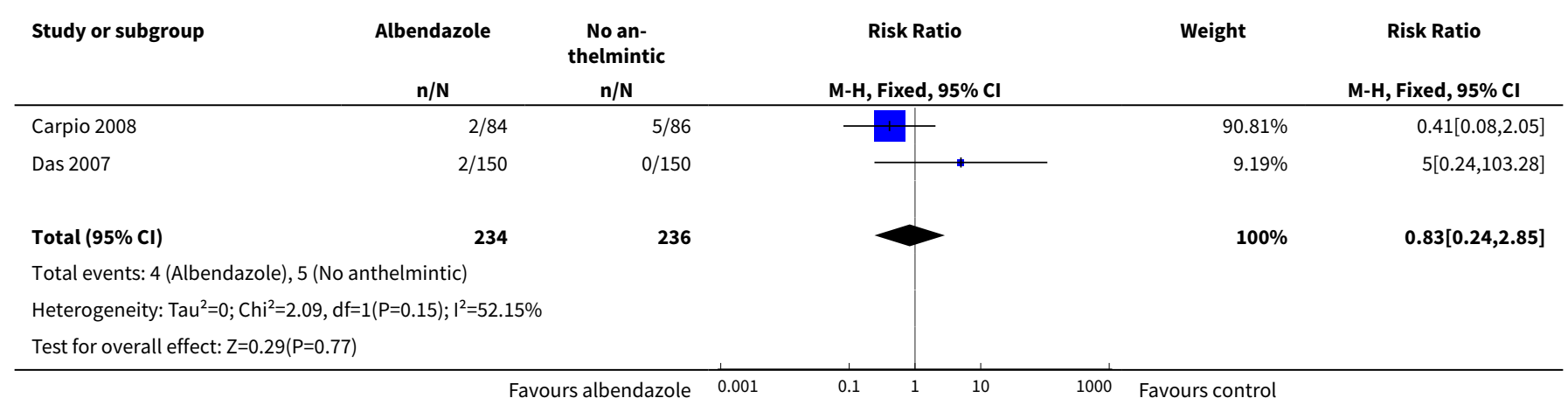

Analysis 1.4. Comparison 1 Albendazole vs placebo or no drug, Outcome 4 Hospital admission, by follow-up period.

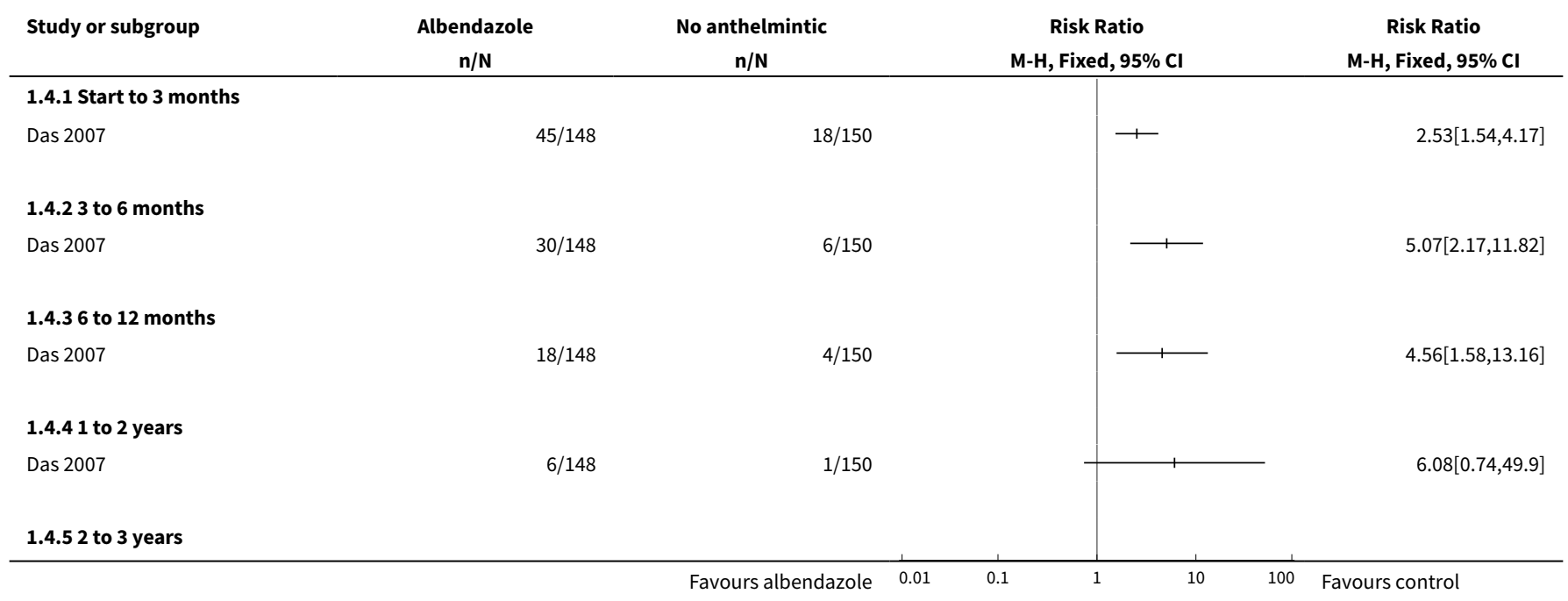




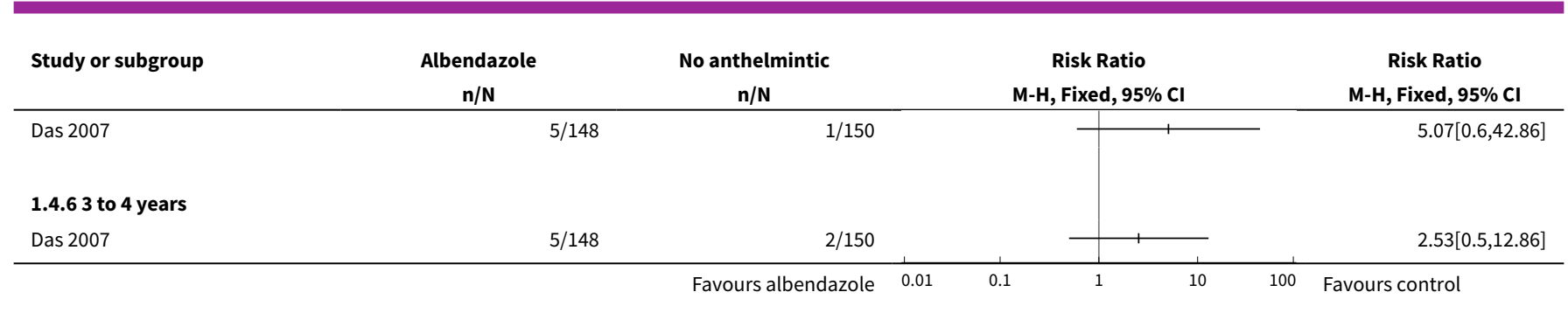

Analysis 1.5. Comparison 1 Albendazole vs placebo or no drug, Outcome 5 Symptoms not resolved after 3 months.

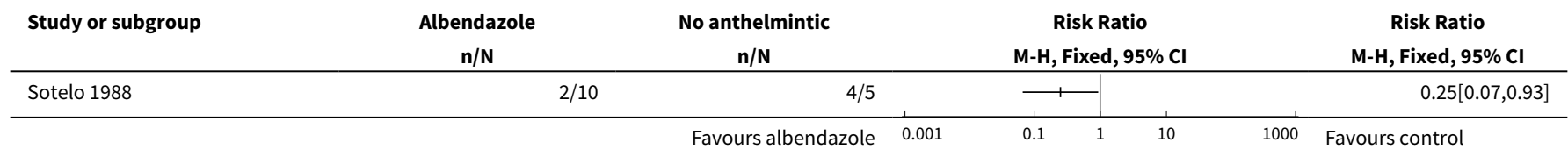

Analysis 1.6. Comparison 1 Albendazole vs placebo or no drug, Outcome 6 Symptoms of encephalopathy (headache, vomiting, or altered sensorium), by period of follow up.

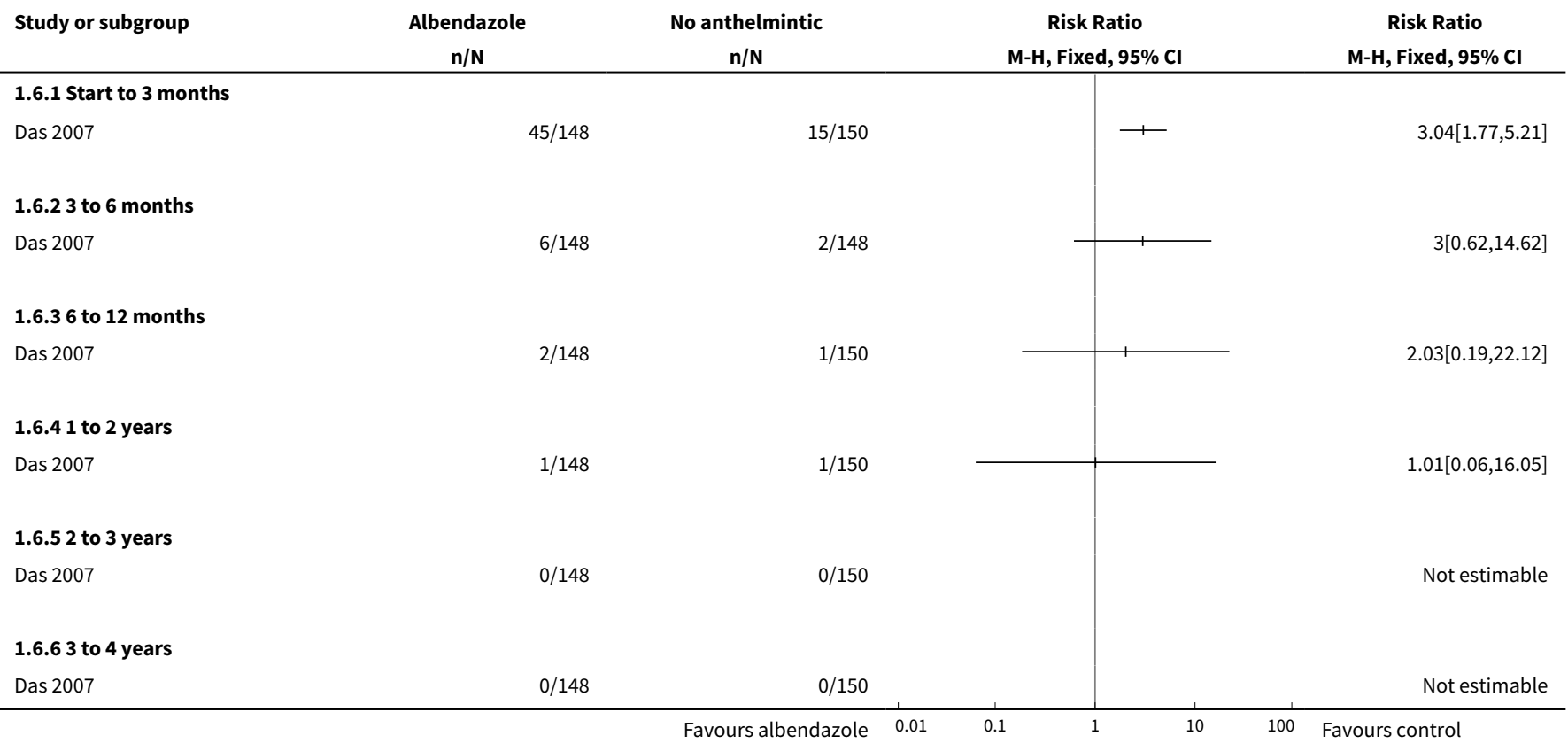

Analysis 1.7. Comparison 1 Albendazole vs placebo or no drug, Outcome 7 Persistence of lesions at trial's final follow-up time (up to 12 months).

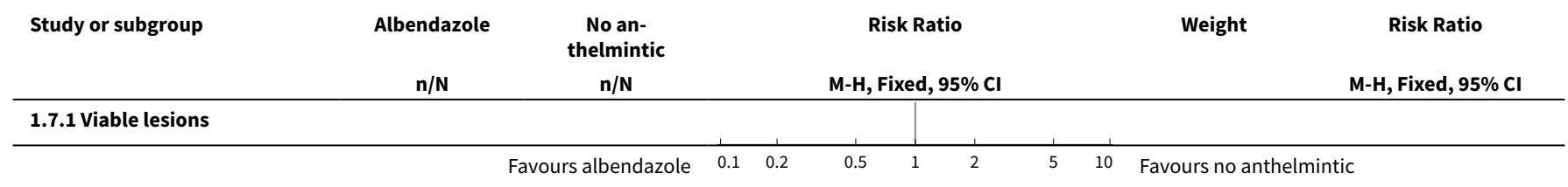




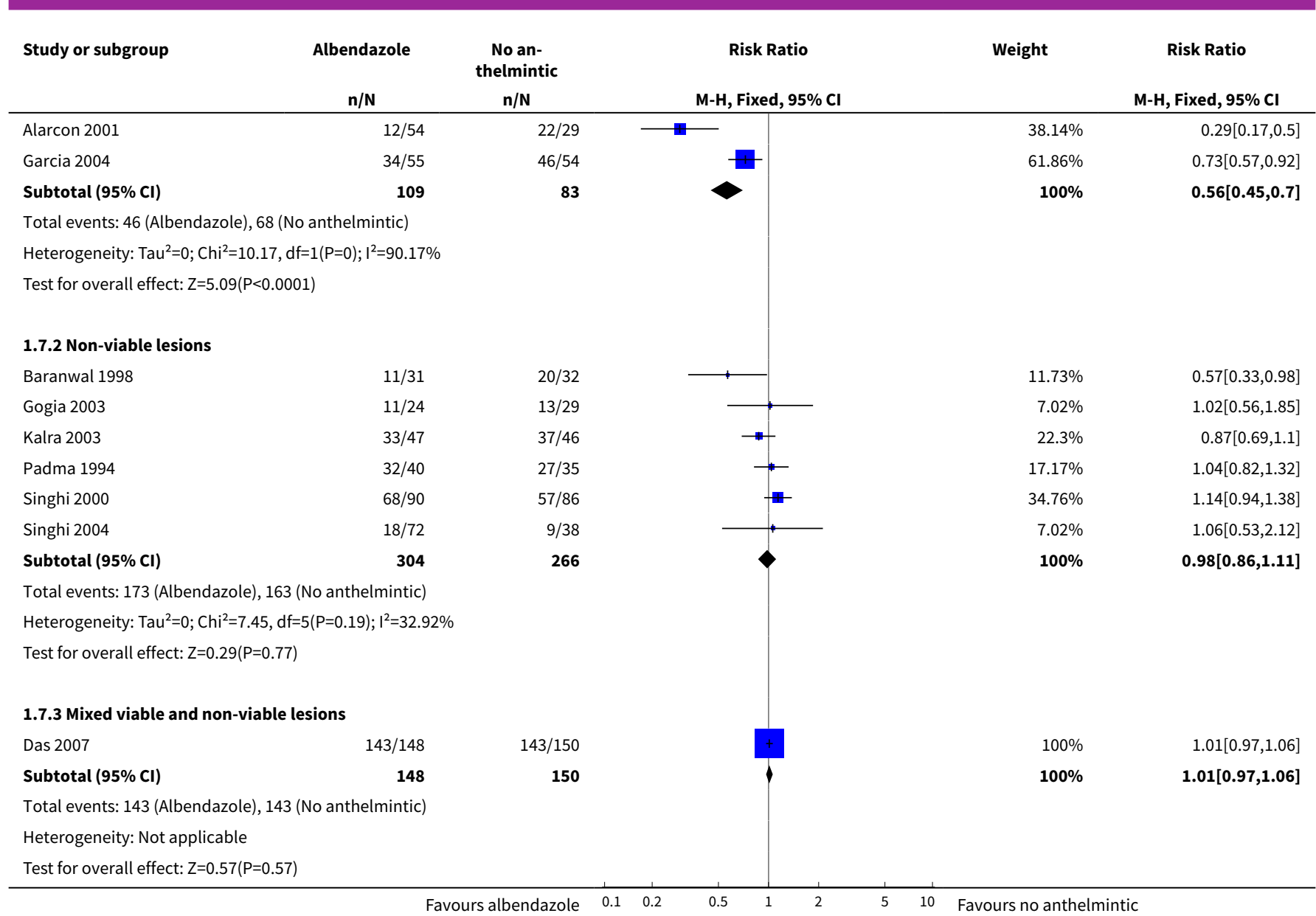

\section{Analysis 1.8. Comparison 1 Albendazole vs placebo or no drug, Outcome 8 Headache during treatment.}

\begin{tabular}{|c|c|c|c|c|c|}
\hline \multirow[t]{2}{*}{ Study or subgroup } & Albendazole & $\begin{array}{c}\text { No an- } \\
\text { thelmintic }\end{array}$ & Risk Ratio & \multirow[t]{2}{*}{ Weight } & \multirow{2}{*}{$\begin{array}{c}\text { Risk Ratio } \\
\text { M-H, Fixed, 95\% Cl }\end{array}$} \\
\hline & $\mathrm{n} / \mathbf{N}$ & $n / N$ & M-H, Fixed, 95\% Cl & & \\
\hline \multicolumn{6}{|l|}{ 1.8.1 Viable lesions } \\
\hline Alarcon 1989 & $6 / 18$ & $0 / 5$ & & $1.39 \%$ & $4.11[0.27,62.7]$ \\
\hline Garcia 2004 & $2 / 57$ & $1 / 59$ & - & $1.79 \%$ & $2.07[0.19,22.21]$ \\
\hline Subtotal $(95 \% \mathrm{Cl})$ & 75 & 64 & & $3.18 \%$ & $2.96[0.49,17.77]$ \\
\hline \multicolumn{6}{|c|}{ Total events: 8 (Albendazole), 1 (No anthelmintic) } \\
\hline \multicolumn{6}{|c|}{ Heterogeneity: Tau $^{2}=0 ; \mathrm{Chi}^{2}=0.14, \mathrm{df}=1(\mathrm{P}=0.71) ; \mathrm{I}^{2}=0 \%$} \\
\hline \multicolumn{6}{|c|}{ Test for overall effect: $Z=1.19(P=0.24)$} \\
\hline \multicolumn{6}{|c|}{ 1.8.2 Non-viable lesions } \\
\hline Alarcon 2001 & $14 / 54$ & $0 / 29$ & & $1.18 \%$ & $15.82[0.98,255.96]$ \\
\hline Subtotal $(95 \% \mathrm{CI})$ & 54 & 29 & & $1.18 \%$ & $15.82[0.98,255.96]$ \\
\hline \multicolumn{6}{|c|}{ Heterogeneity: Not applicable } \\
\hline \multicolumn{6}{|c|}{ Test for overall effect: $\mathrm{Z}=1.94(\mathrm{P}=0.05)$} \\
\hline \multicolumn{6}{|c|}{ 1.8.3 Mixed viable and non-viable lesions } \\
\hline Carpio 2008 & $59 / 84$ & $53 / 86$ & & $95.64 \%$ & $1.14[0.92,1.42]$ \\
\hline
\end{tabular}




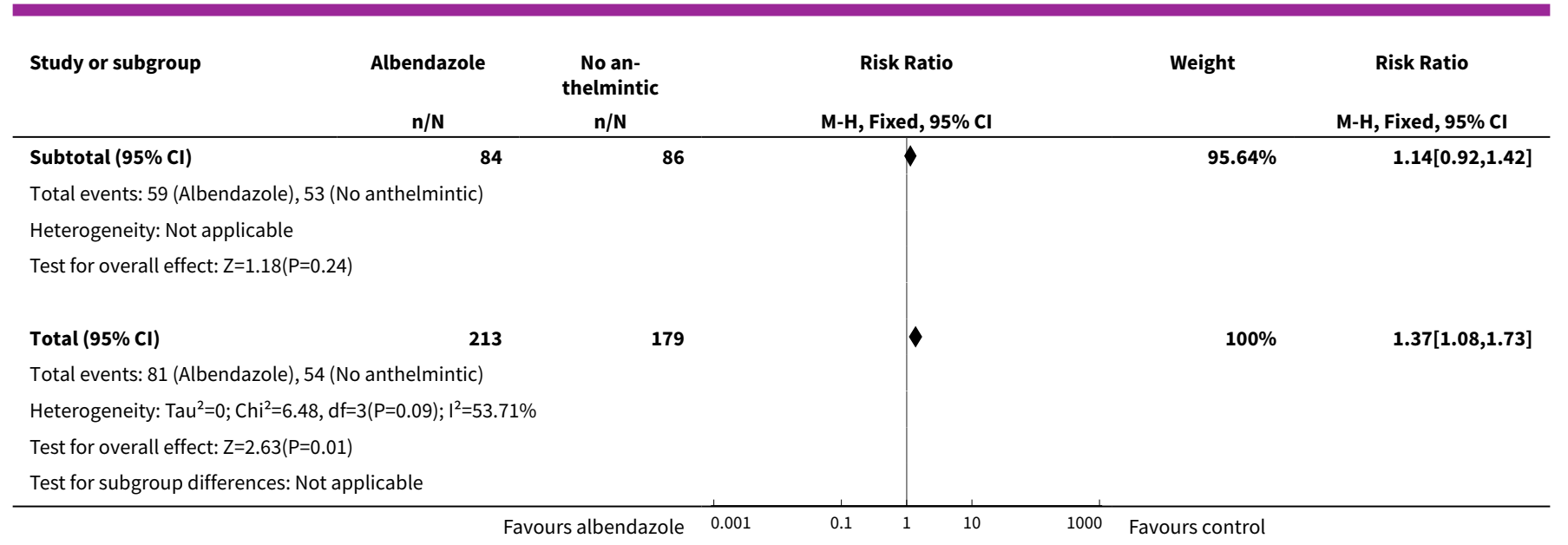

\section{Analysis 1.9. Comparison 1 Albendazole vs placebo or no drug, Outcome 9 Headache during treatment - by corticosteroid use.}

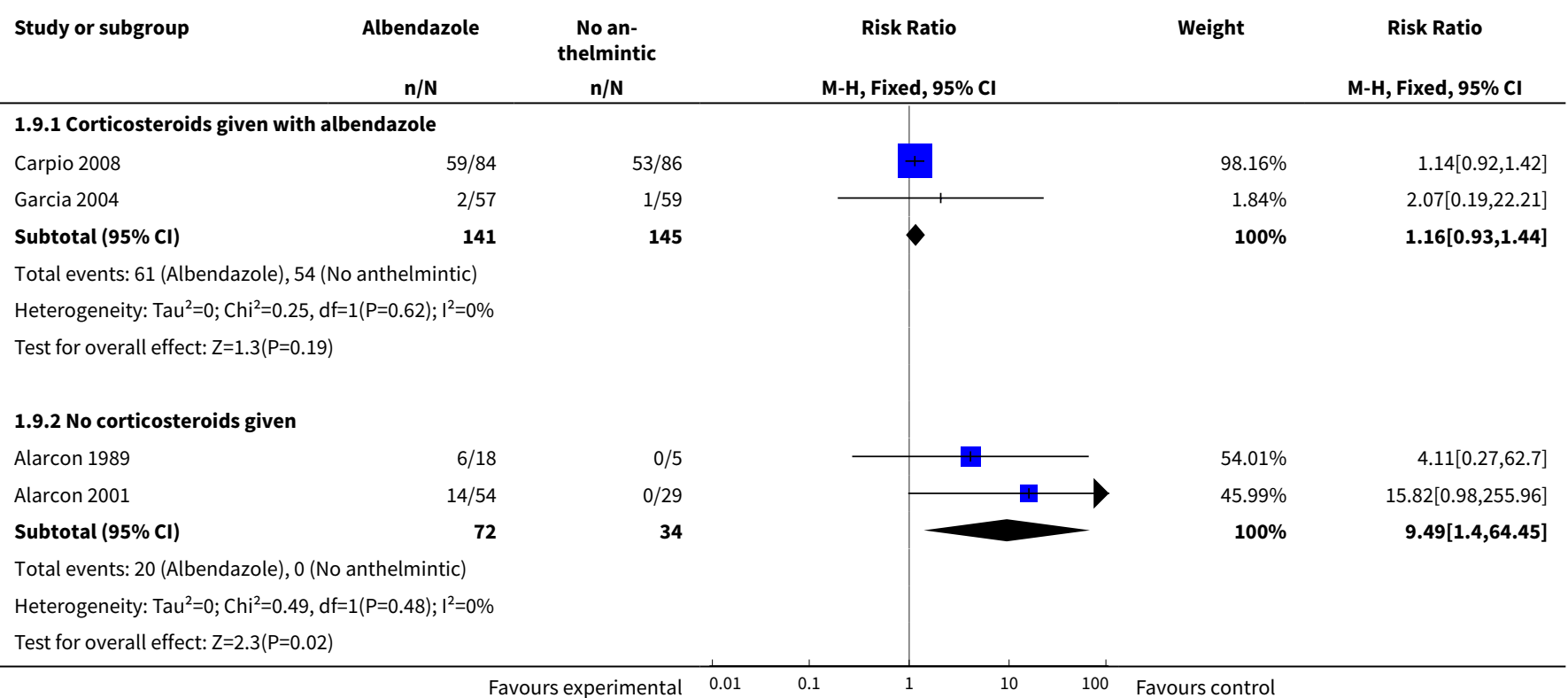

\section{Analysis 1.10. Comparison 1 Albendazole vs placebo or no drug, Outcome 10 Dizziness during treatment.}

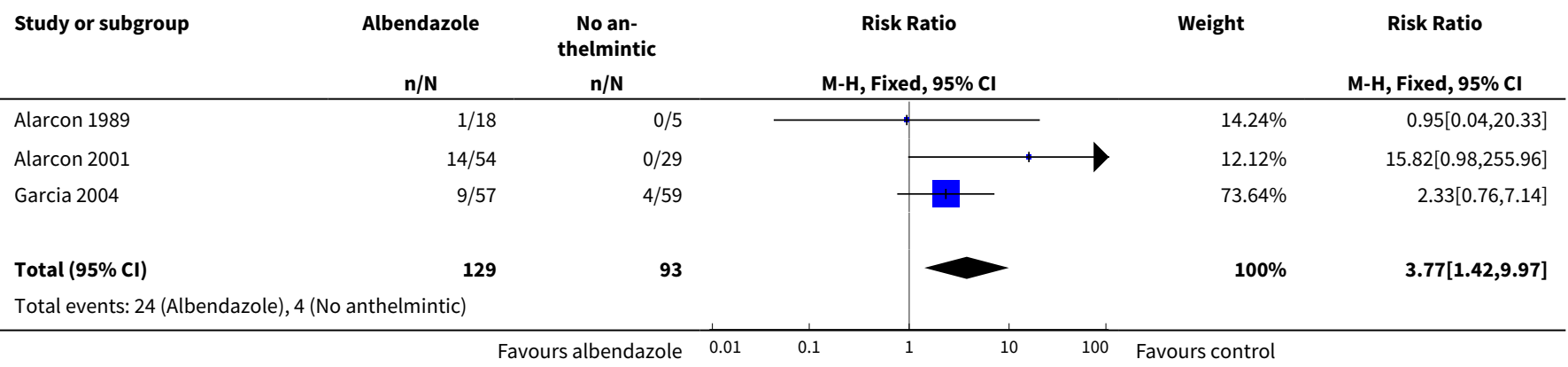




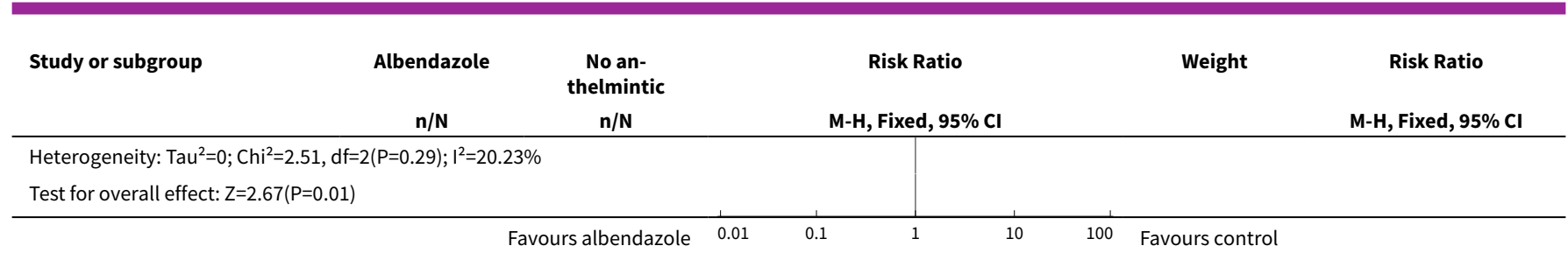

Analysis 1.11. Comparison 1 Albendazole vs placebo or no drug, Outcome 11 Nausea, vomiting, or abdominal pain during treatment.

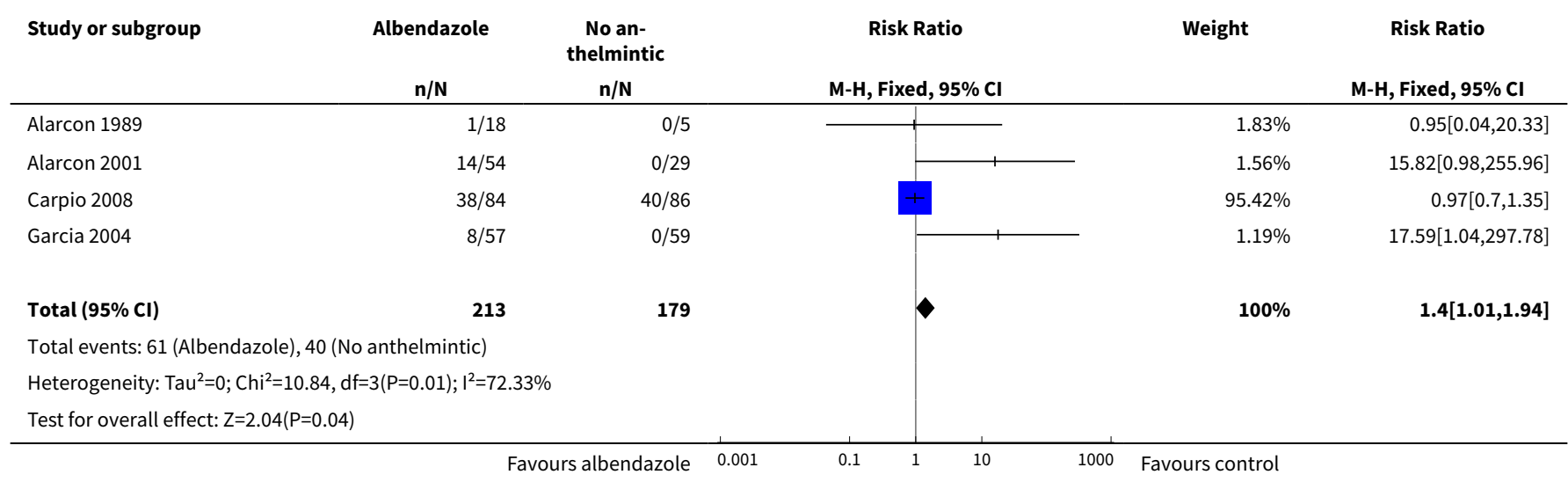

Analysis 1.12. Comparison 1 Albendazole vs placebo or no drug, Outcome 12 Seizures during treatment.

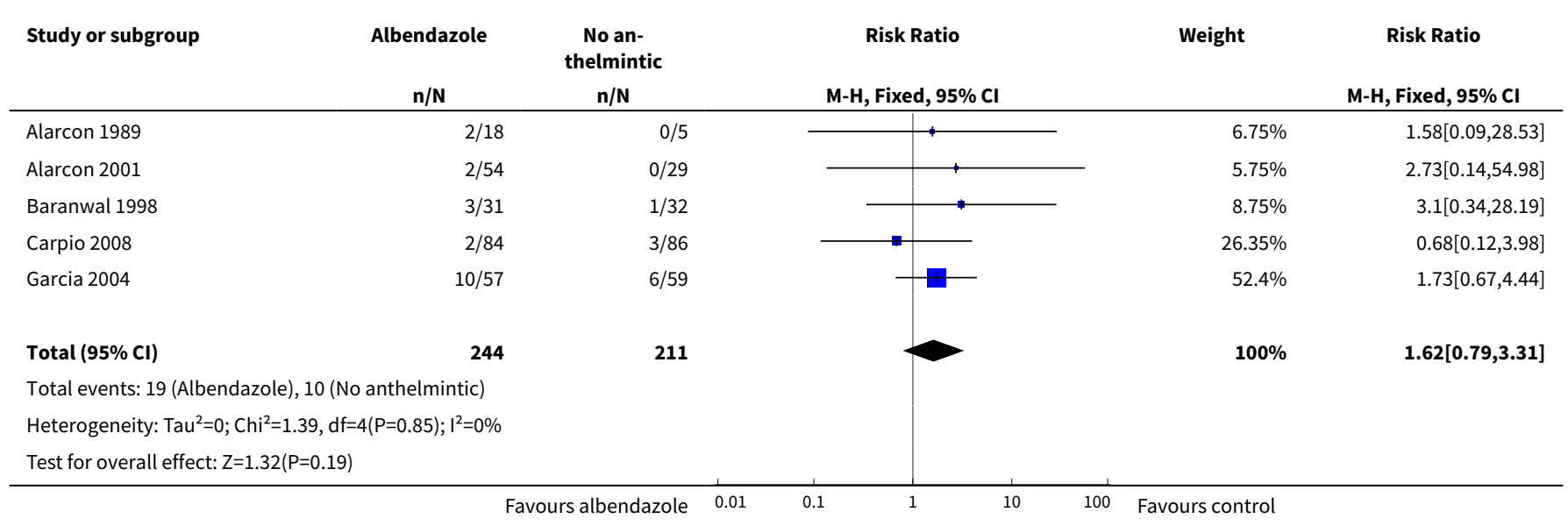


Comparison 2. Praziquantel vs placebo or no drug

\begin{tabular}{lllll}
\hline Outcome or subgroup title & $\begin{array}{l}\text { No. of } \\
\text { studies }\end{array}$ & $\begin{array}{l}\text { No. of } \\
\text { partici- } \\
\text { pants }\end{array}$ & Statistical method & Effect size \\
\hline $\begin{array}{l}1 \text { Symptoms not resolved after } 3 \\
\text { months }\end{array}$ & 1 & & Risk Ratio (M-H, Fixed, 95\% Cl) & Totals not selected \\
\hline $\begin{array}{l}2 \text { Persistence of lesions at follow up } \\
\text { 3 No reduction in number of lesions } \\
\text { at 3 months }\end{array}$ & 1 & 15 & Risk Ratio (M-H, Fixed, 95\% Cl) & $0.35[0.14,0.85]$ \\
\hline $\begin{array}{l}4 \text { Any adverse events during treat- } \\
\text { ment }\end{array}$ & 1 & Risk Ratio (M-H, Fixed, 95\% Cl) & Totals not selected \\
\hline
\end{tabular}

Analysis 2.1. Comparison 2 Praziquantel vs placebo or no drug, Outcome 1 Symptoms not resolved after 3 months.

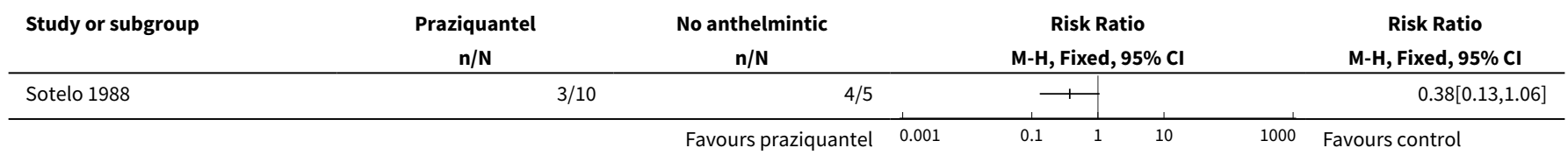

Analysis 2.2. Comparison 2 Praziquantel vs placebo or no drug, Outcome 2 Persistence of lesions at follow up.

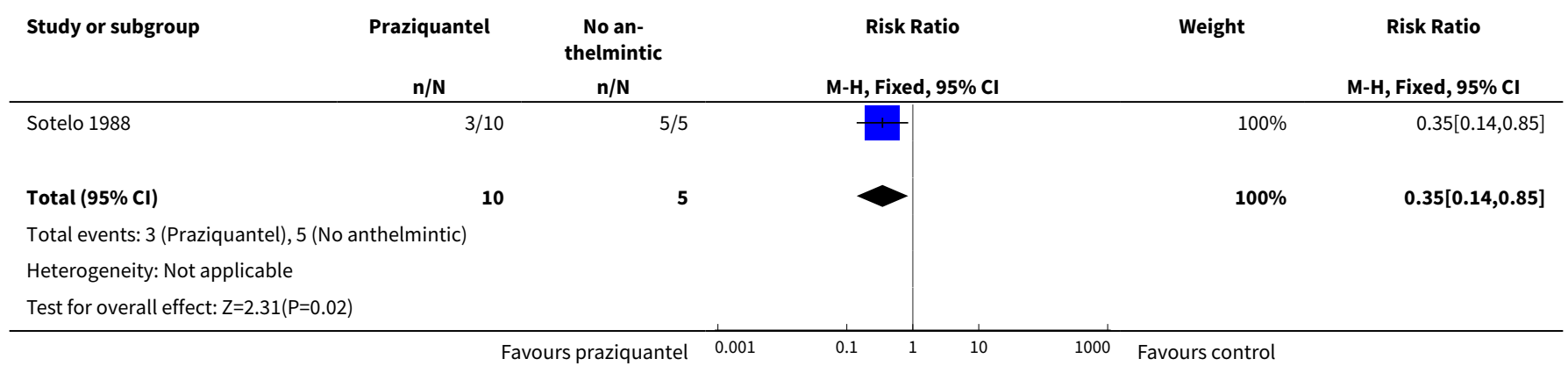

Analysis 2.3. Comparison 2 Praziquantel vs placebo or no drug, Outcome 3 No reduction in number of lesions at 3 months.

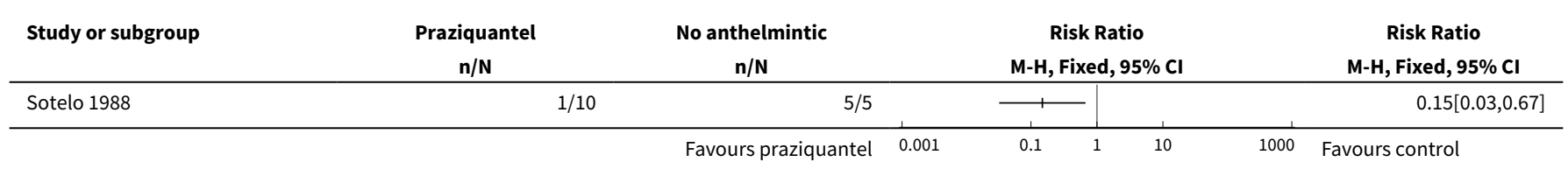


Analysis 2.4. Comparison 2 Praziquantel vs placebo or no drug, Outcome 4 Any adverse events during treatment.

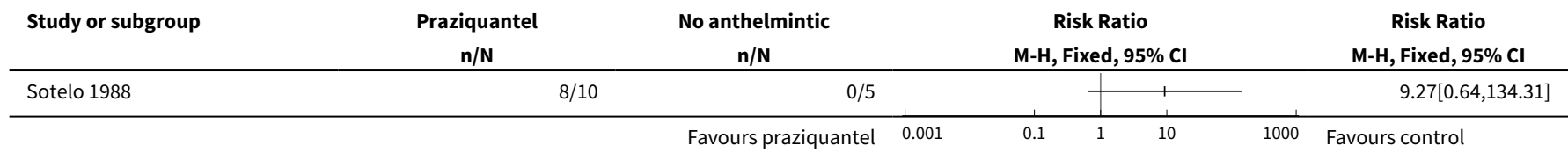

\section{Comparison 3. Albendazole vs praziquantel}

\begin{tabular}{|c|c|c|c|c|}
\hline Outcome or subgroup title & $\begin{array}{l}\text { No. of } \\
\text { studies }\end{array}$ & $\begin{array}{l}\text { No. of } \\
\text { partici- } \\
\text { pants }\end{array}$ & Statistical method & Effect size \\
\hline $\begin{array}{l}1 \text { Recurrence of seizures at fol- } \\
\text { low up }\end{array}$ & 1 & 19 & Risk Ratio (M-H, Fixed, 95\% Cl) & $0.18[0.01,3.35]$ \\
\hline $\begin{array}{l}2 \text { Symptoms not resolved after } \\
3 \text { months }\end{array}$ & 2 & 121 & Risk Ratio (M-H, Fixed, 95\% Cl) & $0.58[0.36,0.92]$ \\
\hline $\begin{array}{l}3 \text { Persistence of lesions at fol- } \\
\text { low up }\end{array}$ & 3 & 154 & Risk Ratio (M-H, Fixed, 95\% Cl) & $0.64[0.45,0.91]$ \\
\hline $\begin{array}{l}4 \text { No reduction in number of } \\
\text { lesions at } 3 \text { months }\end{array}$ & 3 & 149 & Risk Ratio (M-H, Fixed, 95\% Cl) & $0.41[0.19,0.92]$ \\
\hline 5 Adverse events & 3 & & Risk Ratio (M-H, Fixed, 95\% Cl) & Subtotals only \\
\hline $\begin{array}{l}5.1 \text { Headache or vomiting or } \\
\text { both }\end{array}$ & 1 & 20 & Risk Ratio (M-H, Fixed, 95\% Cl) & $0.6[0.19,1.86]$ \\
\hline 5.2 Seizures during treatment & 1 & 20 & Risk Ratio (M-H, Fixed, 95\% Cl) & $0.33[0.02,7.32]$ \\
\hline 5.3 Any adverse event & 2 & 134 & Risk Ratio (M-H, Fixed, 95\% Cl) & $1.12[0.94,1.32]$ \\
\hline
\end{tabular}

Analysis 3.1. Comparison 3 Albendazole vs praziquantel, Outcome 1 Recurrence of seizures at follow up.

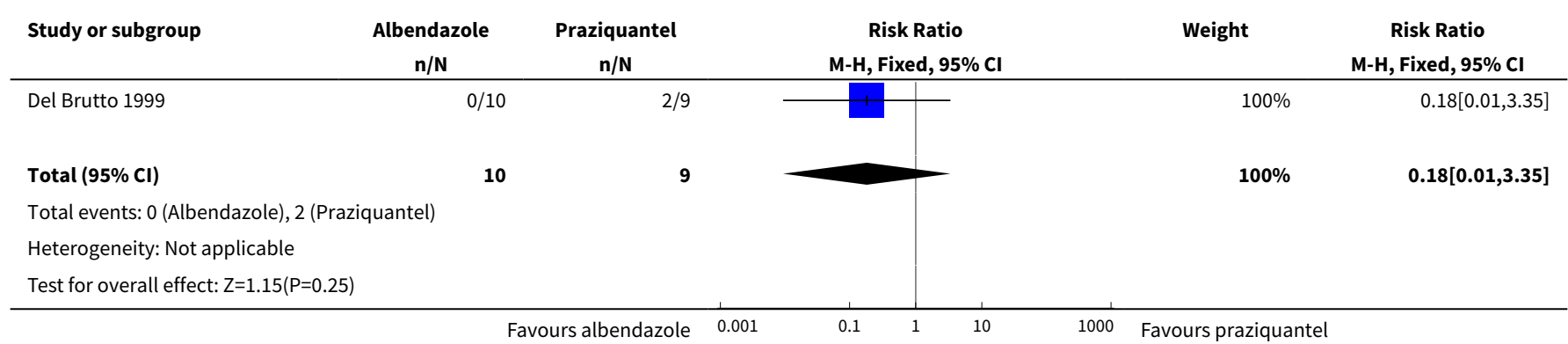


Analysis 3.2. Comparison 3 Albendazole vs praziquantel, Outcome 2 Symptoms not resolved after 3 months.

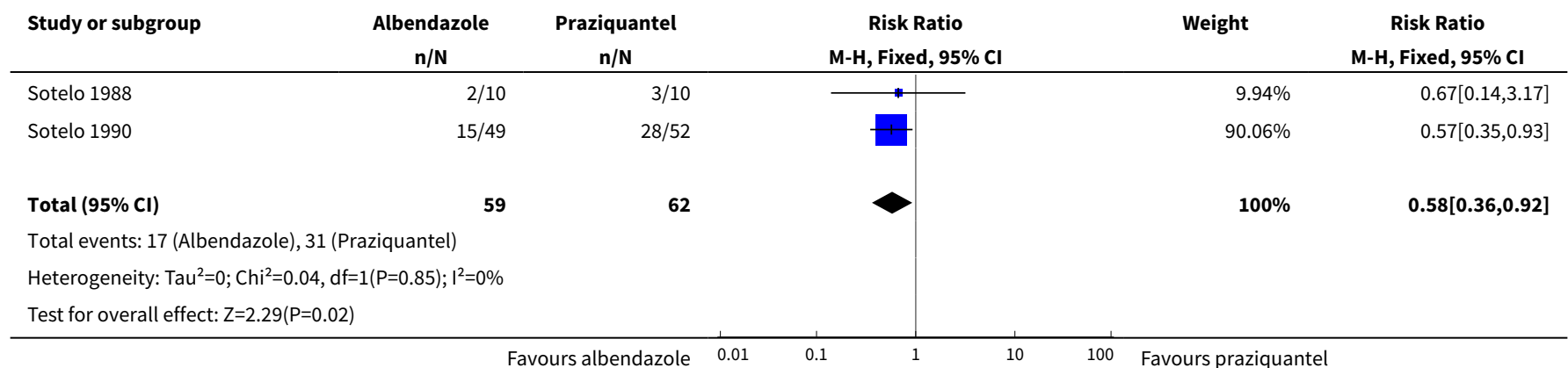

Analysis 3.3. Comparison 3 Albendazole vs praziquantel, Outcome 3 Persistence of lesions at follow up.

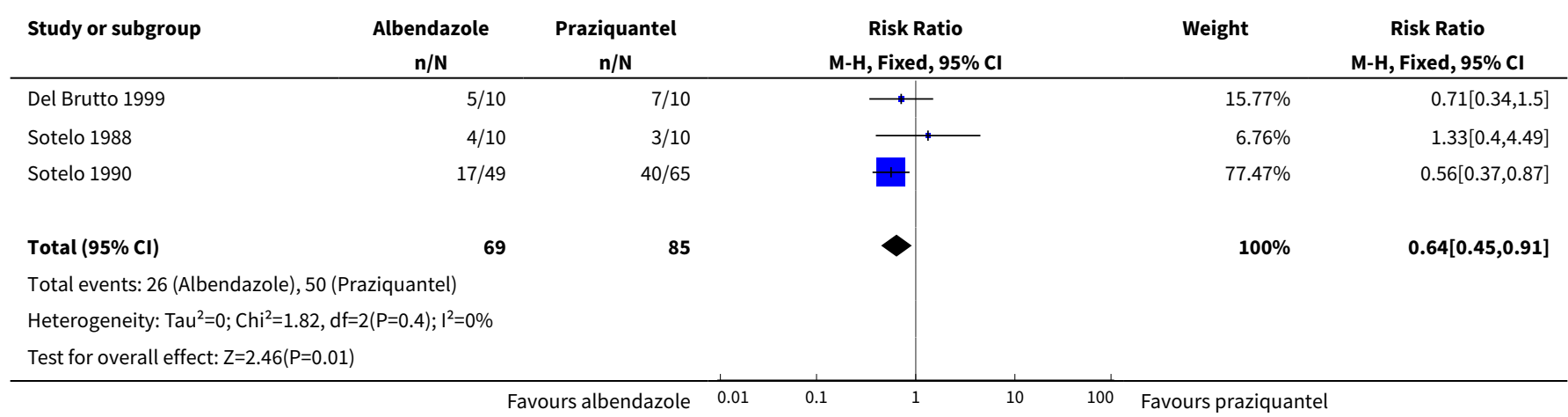

Analysis 3.4. Comparison 3 Albendazole vs praziquantel, Outcome 4 No reduction in number of lesions at 3 months.

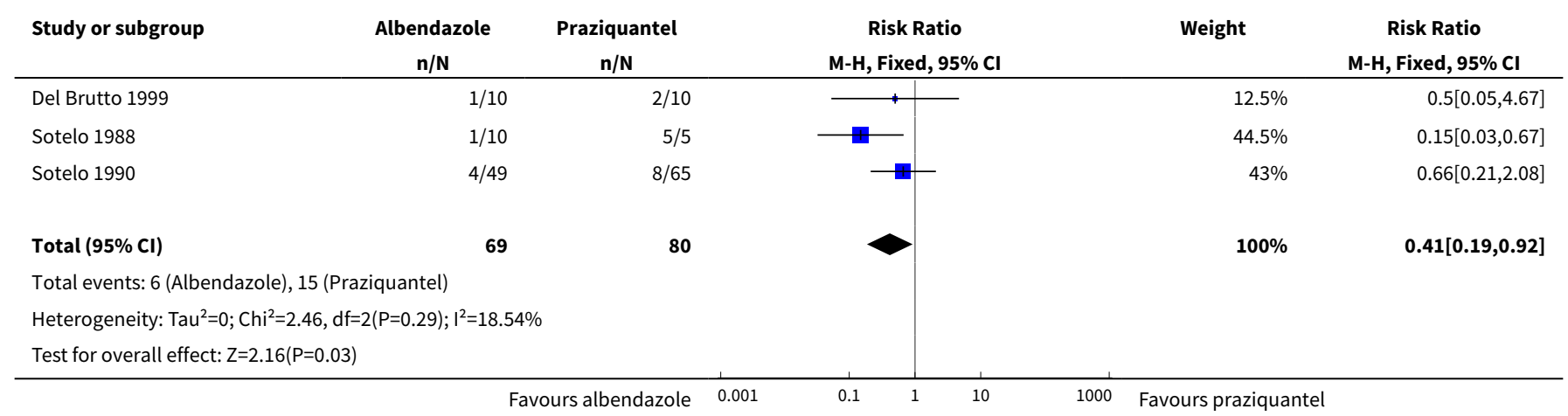

Analysis 3.5. Comparison 3 Albendazole vs praziquantel, Outcome 5 Adverse events.

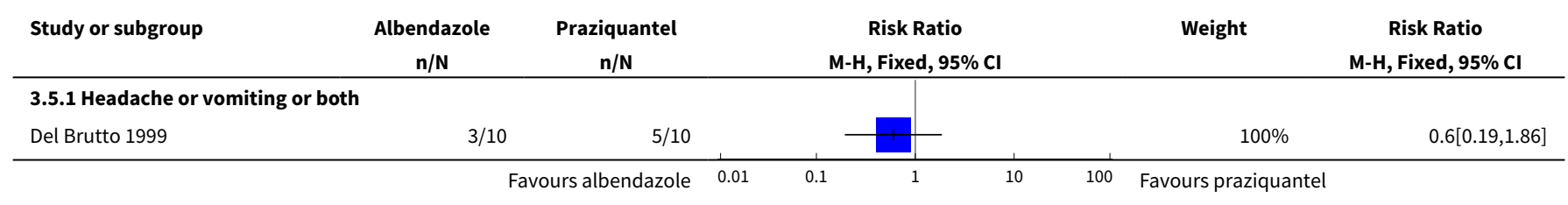




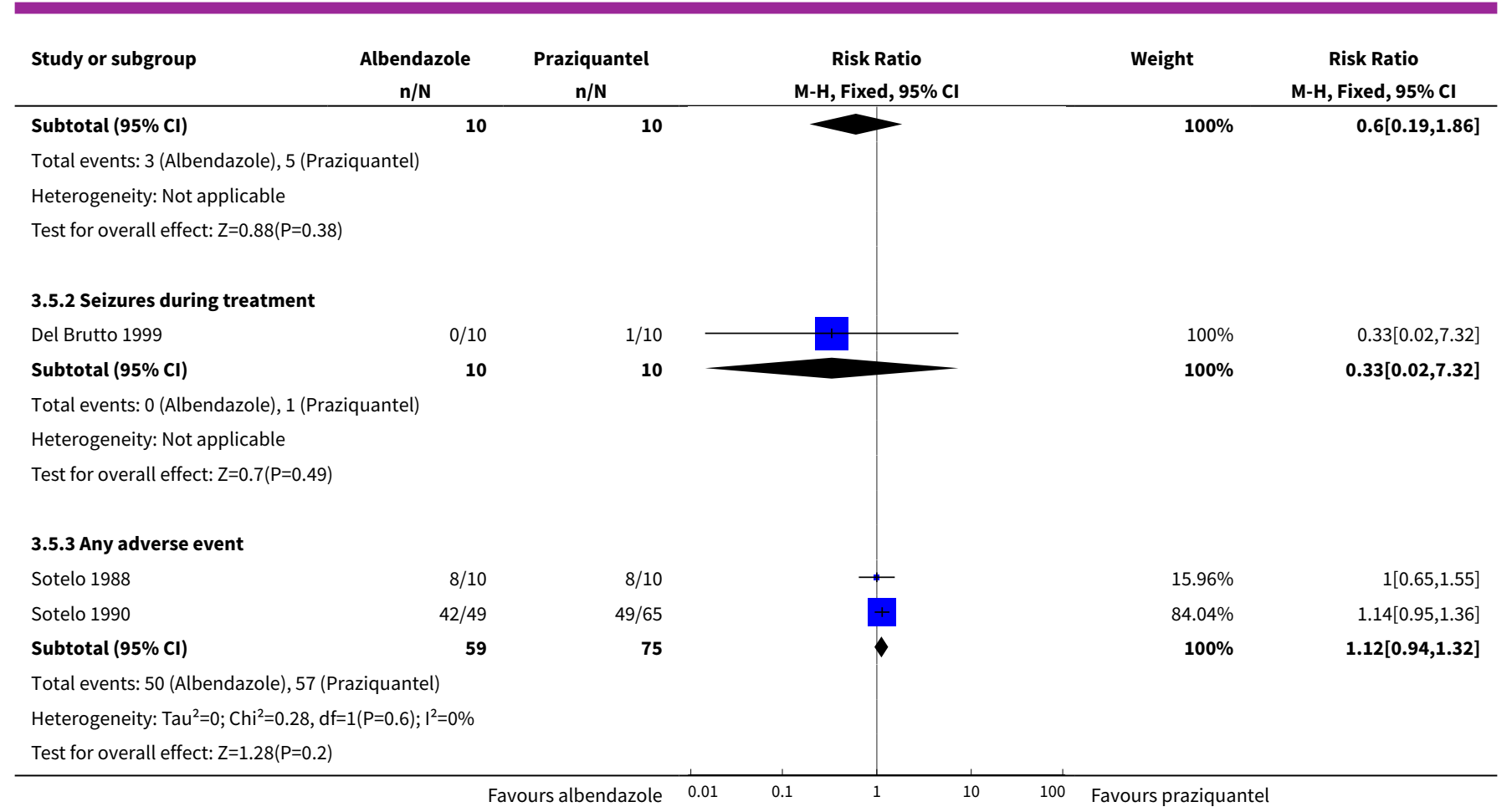

Comparison 4. Albendazole combined with praziquantel vs albendazole alone

\begin{tabular}{lllll}
\hline Outcome or subgroup title & $\begin{array}{l}\text { No. of } \\
\text { studies }\end{array}$ & $\begin{array}{l}\text { No. of } \\
\text { partici- } \\
\text { pants }\end{array}$ & Statistical method & Effect size \\
\hline $\begin{array}{l}1 \text { Recurrence of seizures within } 6 \\
\text { months }\end{array}$ & 1 & 112 & Risk Ratio (M-H, Fixed, 95\% Cl) & $0.93[0.20,4.42]$ \\
\hline $\begin{array}{l}2 \text { Persistence of lesions, by follow-up } \\
\text { period }\end{array}$ & 1 & Risk Ratio (M-H, Fixed, 95\% Cl) & Totals not selected \\
\hline 2.11 month & 1 & Risk Ratio (M-H, Fixed, 95\% Cl) & $0.0[0.0,0.0]$ \\
\hline 2.23 months & 1 & Risk Ratio (M-H, Fixed, 95\% Cl) & $0.0[0.0,0.0]$ \\
\hline 2.36 months & 1 & Risk Ratio (M-H, Fixed, 95\% Cl) & $0.0[0.0,0.0]$ \\
\hline
\end{tabular}

Analysis 4.1. Comparison 4 Albendazole combined with praziquantel vs albendazole alone, Outcome 1 Recurrence of seizures within 6 months.

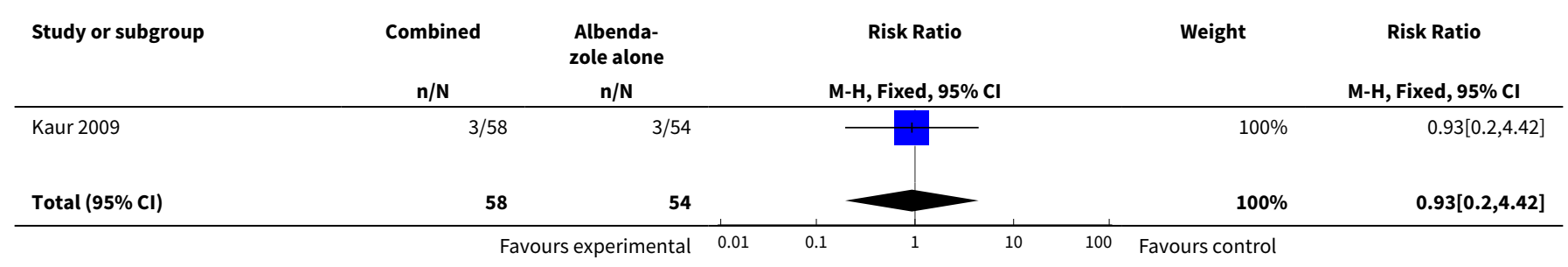




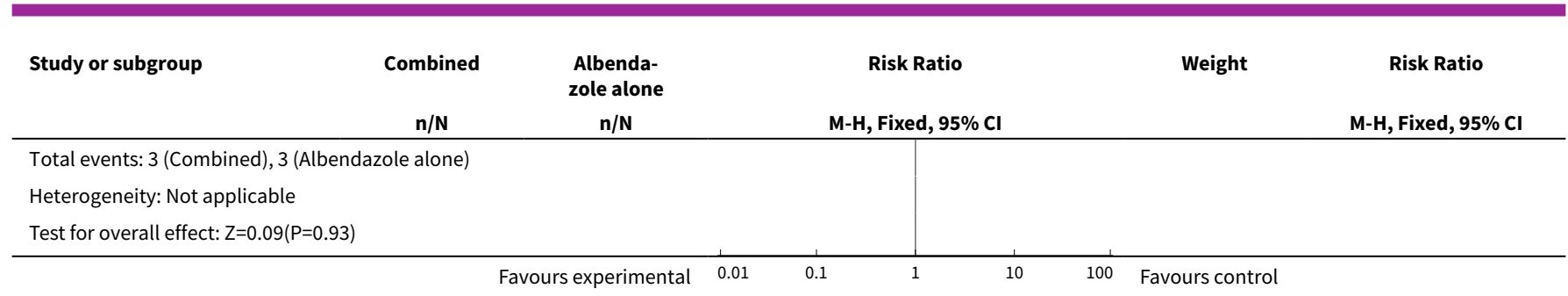

Analysis 4.2. Comparison 4 Albendazole combined with praziquantel vs albendazole alone, Outcome 2 Persistence of lesions, by follow-up period.

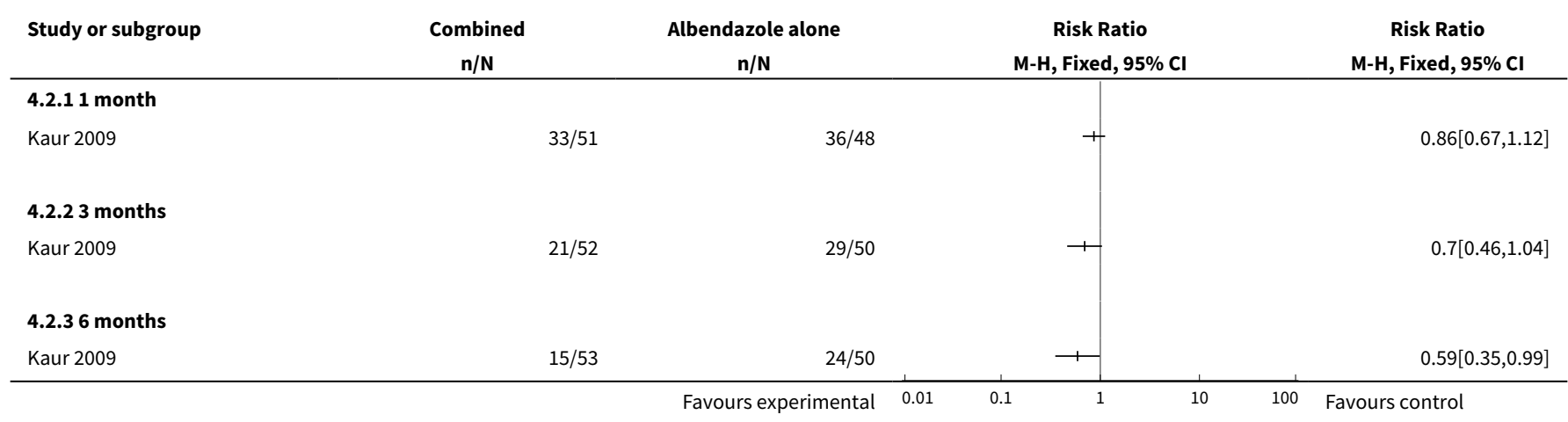

\section{Comparison 5. Albendazole: longer vs shorter duration of treatment}

\begin{tabular}{|c|c|c|c|c|}
\hline Outcome or subgroup title & $\begin{array}{l}\text { No. of } \\
\text { studies }\end{array}$ & $\begin{array}{l}\text { No. of } \\
\text { partici- } \\
\text { pants }\end{array}$ & Statistical method & Effect size \\
\hline $\begin{array}{l}1 \text { Symptoms not resolved after } \\
3 \text { months: } 8 \text { days vs more than } 8 \\
\text { days }\end{array}$ & 2 & & Risk Ratio (M-H, Fixed, 95\% Cl) & Totals not selected \\
\hline 1.1 Viable lesions & 1 & & Risk Ratio (M-H, Fixed, 95\% Cl) & $0.0[0.0,0.0]$ \\
\hline $\begin{array}{l}\text { 1.2 Mixed viable and non-viable le- } \\
\text { sions }\end{array}$ & 1 & & Risk Ratio (M-H, Fixed, 95\% Cl) & $0.0[0.0,0.0]$ \\
\hline $\begin{array}{l}2 \text { Persistence of lesions at longest } \\
\text { length of follow up: } 7 \text { or } 8 \text { days vs. } \\
\text { more than } 7 \text { to } 8 \text { days }\end{array}$ & 5 & & Risk Ratio (M-H, Fixed, 95\% Cl) & Subtotals only \\
\hline 2.1 Viable lesions & 2 & 103 & Risk Ratio (M-H, Fixed, 95\% Cl) & $0.96[0.52,1.76]$ \\
\hline 2.2 Non-viable lesions & 2 & 159 & Risk Ratio (M-H, Fixed, 95\% Cl) & $0.98[0.64,1.50]$ \\
\hline $\begin{array}{l}2.3 \text { Mixed viable and non-viable le- } \\
\text { sions }\end{array}$ & 2 & 79 & Risk Ratio (M-H, Fixed, 95\% Cl) & $0.85[0.53,1.36]$ \\
\hline $\begin{array}{l}3 \text { No reduction in number of le- } \\
\text { sions at } 3 \text { months follow up, by } \\
\text { length of treatment comparison }\end{array}$ & 2 & & Risk Ratio (M-H, Fixed, 95\% Cl) & Subtotals only \\
\hline
\end{tabular}




\begin{tabular}{|c|c|c|c|c|}
\hline Outcome or subgroup title & $\begin{array}{l}\text { No. of } \\
\text { studies }\end{array}$ & $\begin{array}{l}\text { No. of } \\
\text { partici- } \\
\text { pants }\end{array}$ & Statistical method & Effect size \\
\hline 3.18 days $v s>8$ days & 2 & 102 & Risk Ratio (M-H, Fixed, 95\% Cl) & $0.69[0.17,2.74]$ \\
\hline 4 Adverse events & 5 & & Risk Ratio (M-H, Fixed, 95\% CI) & Subtotals only \\
\hline 4.1 Headache during treatment & 2 & 72 & Risk Ratio (M-H, Fixed, 95\% Cl) & $1.22[0.58,2.58]$ \\
\hline 4.2 Seizures during treatment & 2 & 72 & Risk Ratio (M-H, Fixed, 95\% Cl) & $1.0[0.15,6.59]$ \\
\hline $\begin{array}{l}4.3 \text { Nausea or gastrointestinal } \\
\text { symptoms }\end{array}$ & 4 & 244 & Risk Ratio (M-H, Fixed, 95\% Cl) & $0.54[0.30,0.97]$ \\
\hline 4.4 Any adverse event & 1 & 49 & Risk Ratio (M-H, Fixed, 95\% Cl) & $0.95[0.75,1.19]$ \\
\hline $\begin{array}{l}5 \text { Persistence of lesions (viable le- } \\
\text { sions only): } 3 \text { days vs } 8 \text { days }\end{array}$ & 1 & 54 & Risk Ratio (M-H, Fixed, 95\% Cl) & $1.0[0.37,2.71]$ \\
\hline
\end{tabular}

Analysis 5.1. Comparison 5 Albendazole: longer vs shorter duration of treatment, Outcome 1 Symptoms not resolved after 3 months: 8 days vs more than 8 days.

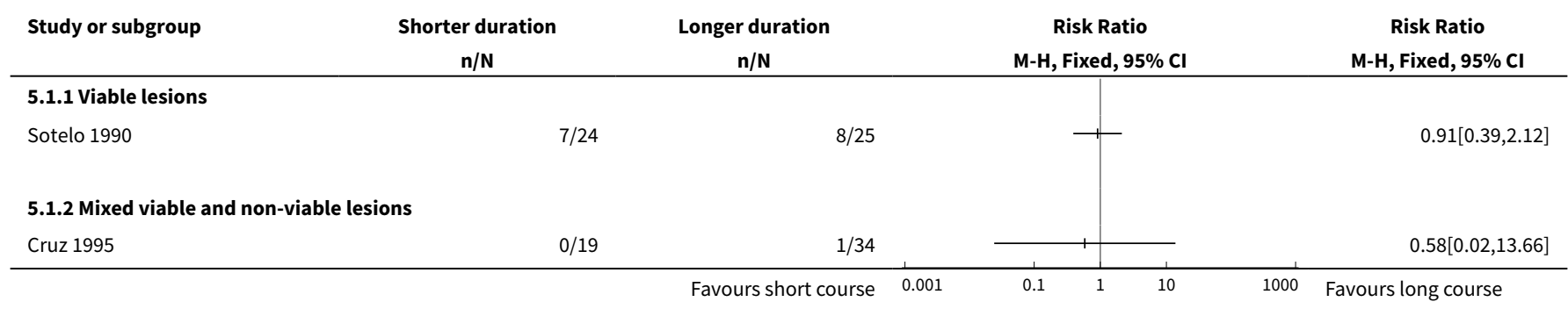

Analysis 5.2. Comparison 5 Albendazole: longer vs shorter duration of treatment, Outcome 2 Persistence of lesions at longest length of follow up: 7 or 8 days vs. more than $\mathbf{7}$ to 8 days.

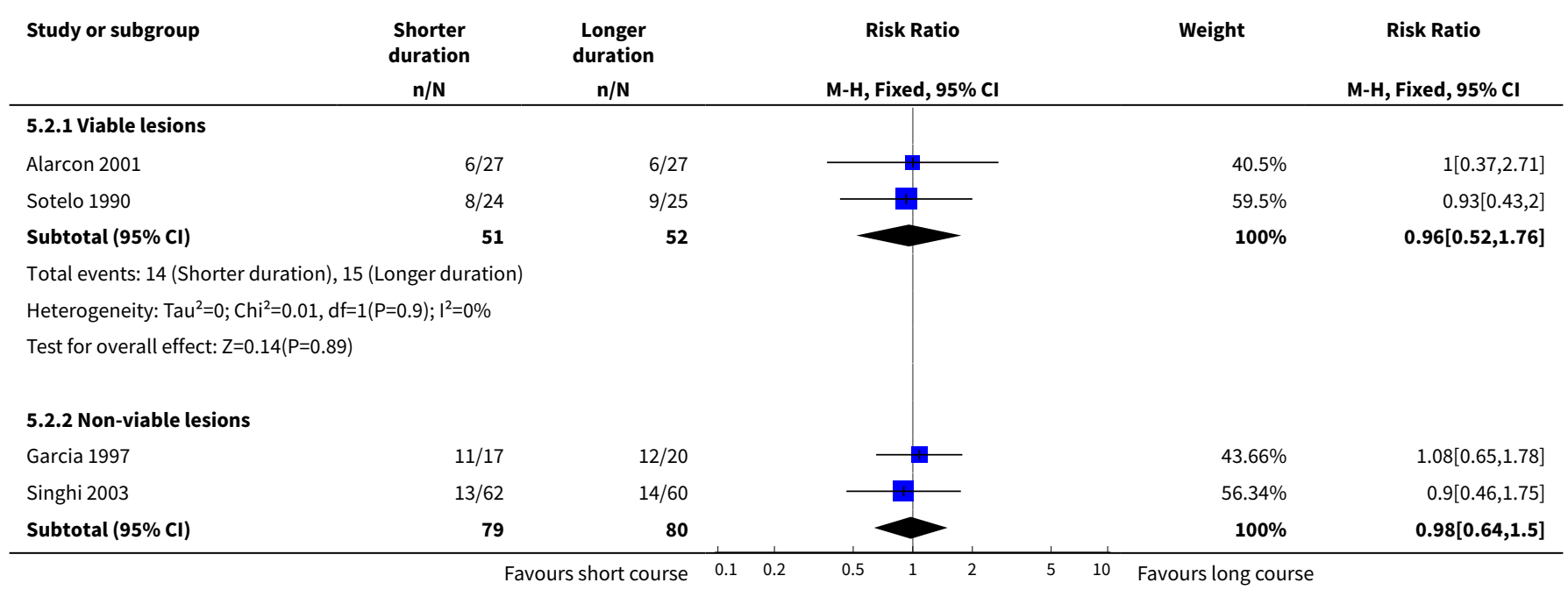




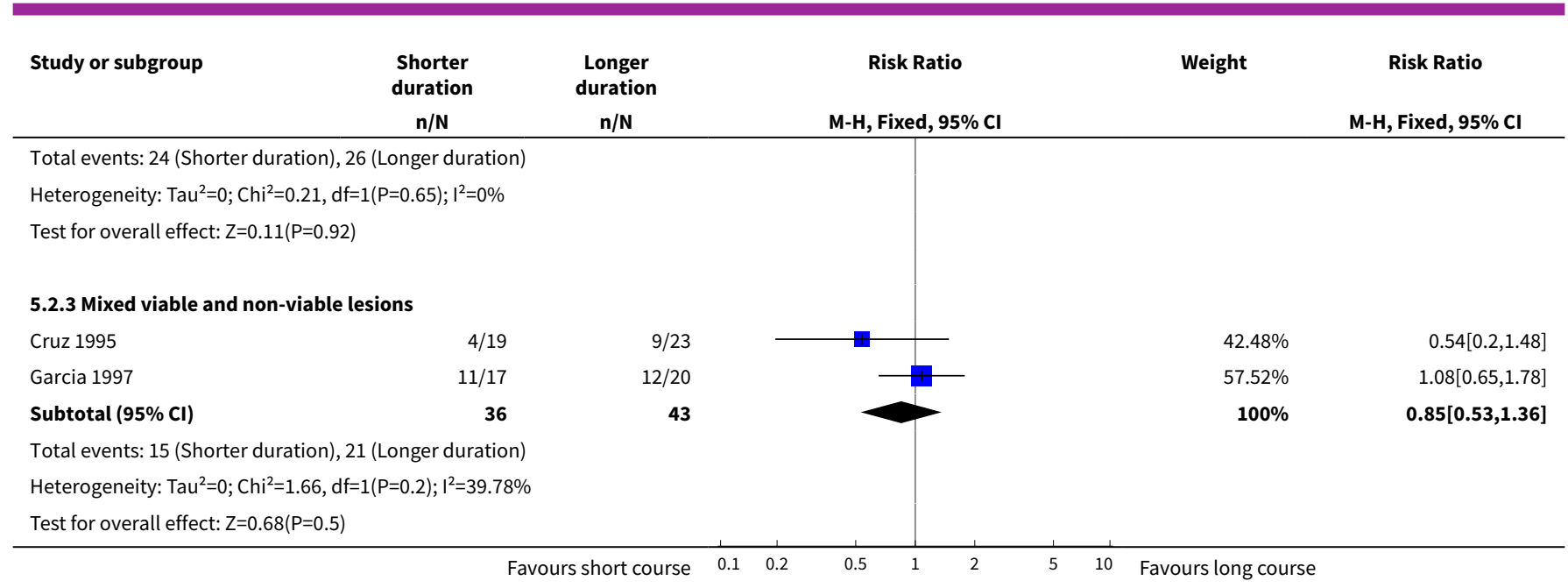

Analysis 5.3. Comparison 5 Albendazole: longer vs shorter duration of treatment, Outcome 3 No reduction in number of lesions at 3 months follow up, by length of treatment comparison.

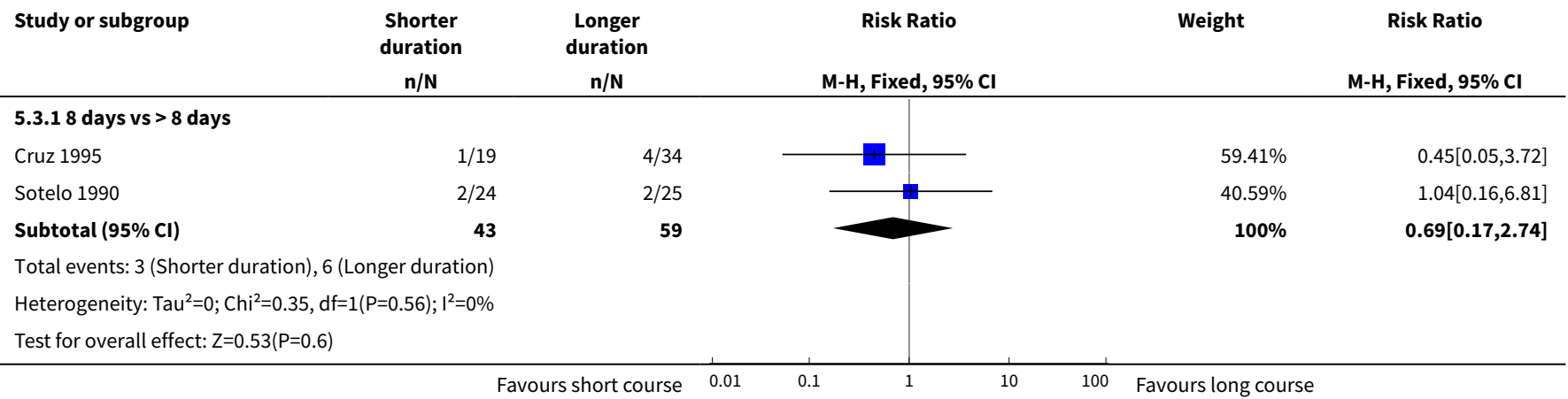

Analysis 5.4. Comparison 5 Albendazole: longer vs shorter duration of treatment, Outcome 4 Adverse events.

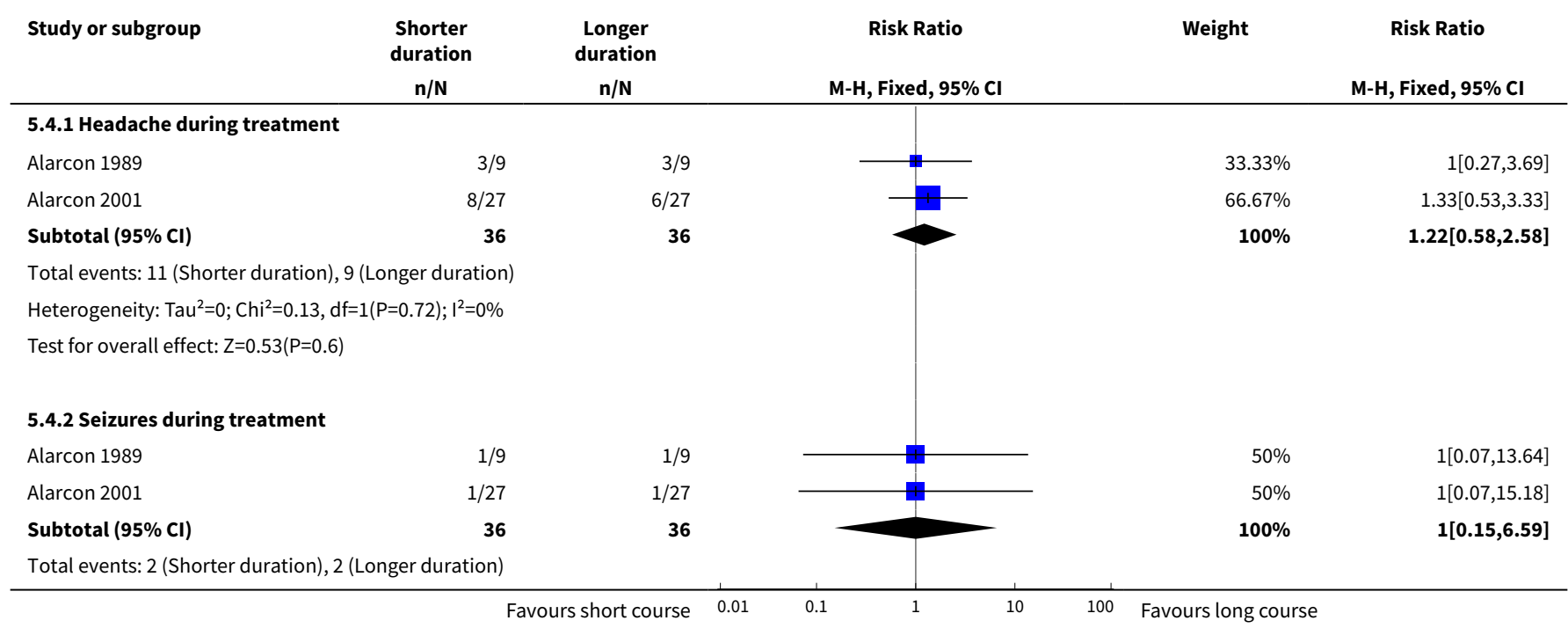




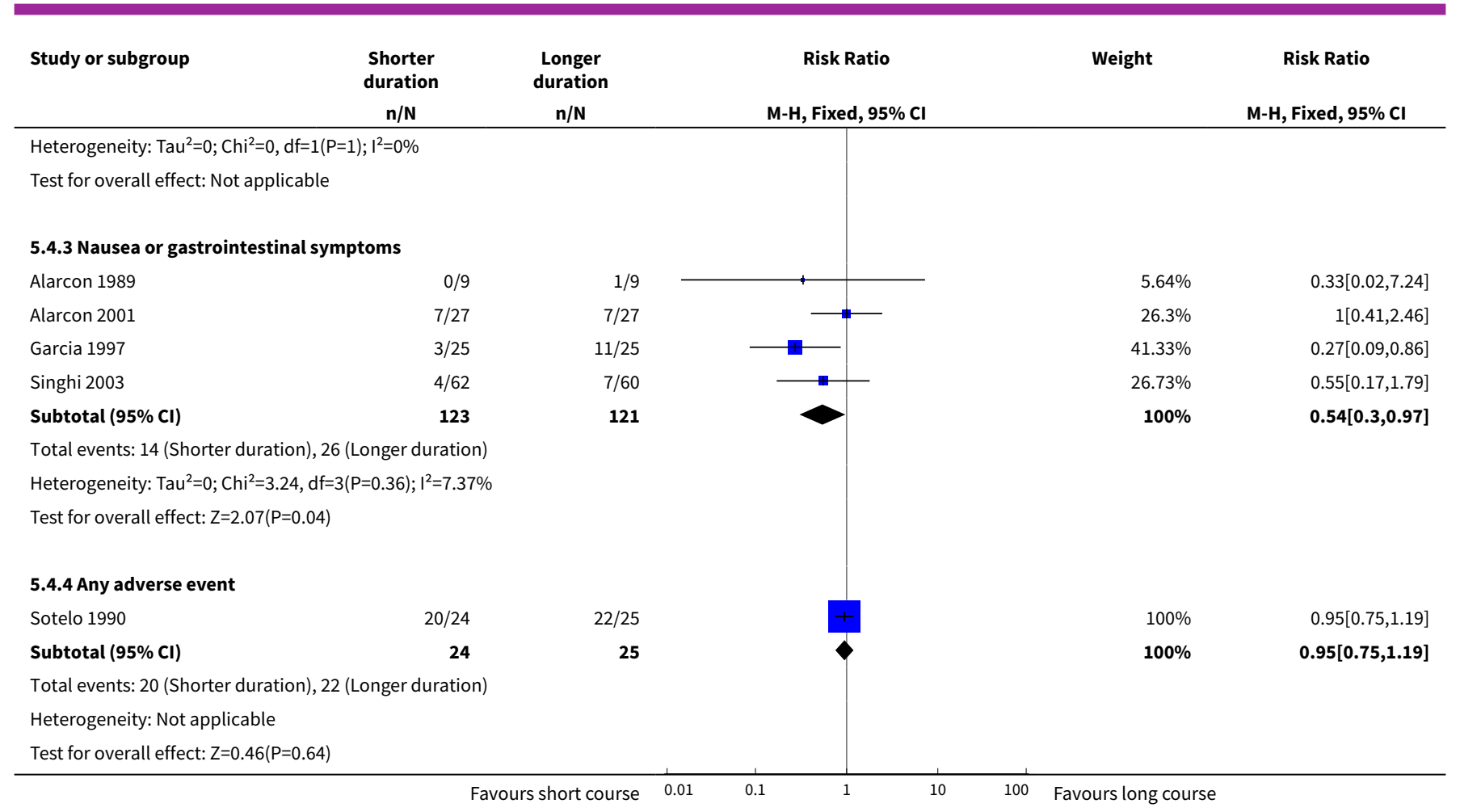

Analysis 5.5. Comparison 5 Albendazole: longer vs shorter duration of treatment, Outcome 5 Persistence of lesions (viable lesions only): 3 days vs 8 days.

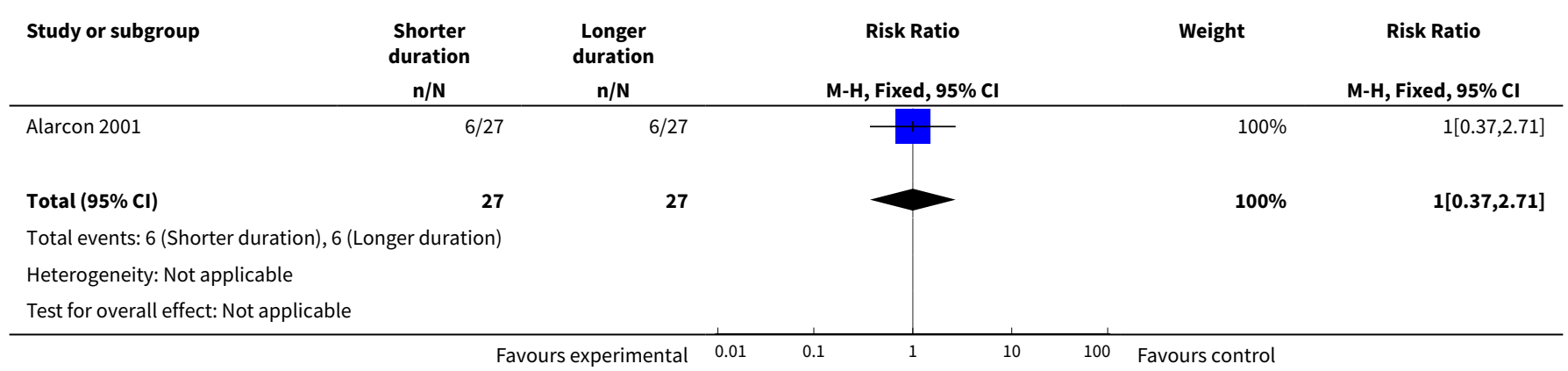

\section{Comparison 6. Albendazole: with corticosteroids vs without corticosteroids}

\begin{tabular}{lllll}
\hline Outcome or subgroup title & $\begin{array}{l}\text { No. of } \\
\text { studies }\end{array}$ & $\begin{array}{l}\text { No. of } \\
\text { partici- } \\
\text { pants }\end{array}$ & Statistical method & Effect size \\
\hline $\begin{array}{l}1 \text { Recurrence of seizures between weeks } \\
1 \text { and } 72\end{array}$ & 1 & Risk Ratio (M-H, Fixed, 95\% Cl) & Totals not selected \\
\hline 2 Persistence of lesions at 6 months & 1 & Risk Ratio (M-H, Fixed, 95\% Cl) & Totals not selected \\
\hline
\end{tabular}


Analysis 6.1. Comparison 6 Albendazole: with corticosteroids vs without corticosteroids, Outcome 1 Recurrence of seizures between weeks 1 and 72 .

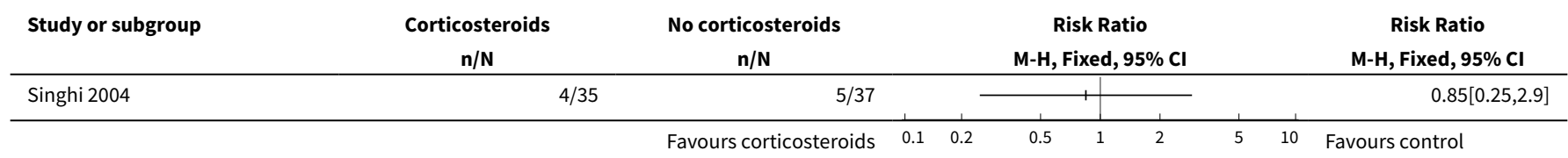

Analysis 6.2. Comparison 6 Albendazole: with corticosteroids vs without corticosteroids, Outcome 2 Persistence of lesions at 6 months.

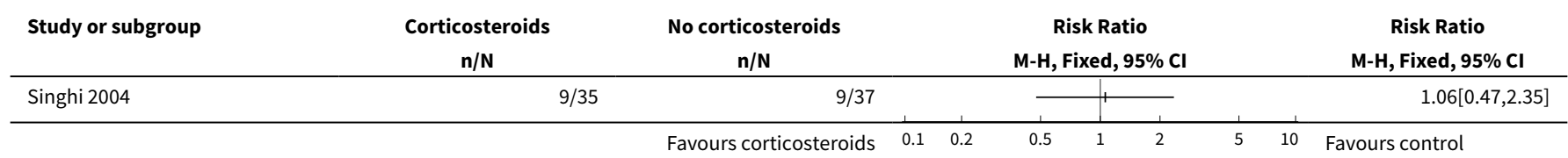

\section{APPENDICES}

Appendix 1. Search methods: detailed search strategies

\begin{tabular}{|c|c|c|c|c|c|}
\hline $\begin{array}{l}\text { Search } \\
\text { set }\end{array}$ & CIDG SRa & CENTRAL & MEDLINEb & EMBASEb & LILACS $b$ \\
\hline 1 & $\begin{array}{l}\text { Taenia soli- } \\
\text { um }\end{array}$ & $\begin{array}{l}\text { NEURO- } \\
\text { CYSTICER- } \\
\text { COSIS }\end{array}$ & Taenia solium & Taenia solium & Taenia solium \\
\hline 2 & $\begin{array}{l}\text { cysticerco- } \\
\text { sis }\end{array}$ & $\begin{array}{l}\text { Taenia } \\
\text { solium }\end{array}$ & cysticercosis & neurocysticercosis & neurocysticercosis \\
\hline 3 & $\begin{array}{l}\text { neurocys- } \\
\text { ticercosis }\end{array}$ & 1 or 2 & neurocysticercosis & BRAIN CYSTICERCOSIS & 1 or 2 \\
\hline 4 & - & - & 1 or 2 or 3 & 1 or 2 or 3 & albendazole \\
\hline 5 & - & - & albendazole & albendazole & praziquantel \\
\hline 6 & - & - & praziquantel & praziquantel & metrifonate \\
\hline 7 & - & - & pyquiton & metrifonate & 4 or 5 or 6 \\
\hline 8 & - & - & metrifonate & 5 or 6 or 7 & 3 and 7 \\
\hline 9 & - & - & 5 or 6 or 7 or 8 & 3 and 8 & - \\
\hline 10 & - & - & 4 and 9 & Limit 9 to human & - \\
\hline 11 & - & - & Limit 10 to human & - & - \\
\hline
\end{tabular}


aCochrane Infectious Diseases Group Specialized Register.

bSearch terms used in combination with the search strategy for retrieving trials developed by The Cochrane Collaboration (Lefebvre 2008); upper case: MeSH or EMTREE heading; lower case: free text term.

\section{Appendix 2. Trial description: lesion type}

\begin{tabular}{lll}
\hline Lesion type & No. trials & Trial \\
\hline $\begin{array}{l}\text { Viable, non-enhancing, or without surrounding oede- } \\
\text { ma, or, if mixed, at least one viable lesion per partici- } \\
\text { pant }\end{array}$ & 7 & $\begin{array}{l}\text { Alarcon 1989; Sotelo 1990; Garcia 1997; Del Brutto } \\
\text { 1999; Alarcon 2001; Garcia 2004 }\end{array}$ \\
\hline $\begin{array}{lll}\text { Non-viable, enhancing or with surrounding oedema } \\
\text { any stage of lesion(s) or types of lesion not described }\end{array}$ & 7 & $\begin{array}{l}\text { Padma 1994; Baranwal 1998; Singhi 2000; Gogia 2003; } \\
\text { Kalra 2003; Singhi 2003; Singhi 2004; De Souza 2009; } \\
\text { Kaur 2009 }\end{array}$ \\
\hline
\end{tabular}

WHAT'S NEW

\begin{tabular}{lll}
\hline Date & Event & Description \\
\hline 15 February 2010 & Amended & corrected search dates in abstract \\
\hline 1 September 2009 & $\begin{array}{l}\text { New citation required and conclusions } \\
\text { have changed }\end{array}$ & $\begin{array}{l}\text { This review replaces an earlier Cochrane Review 'Drugs for treat- } \\
\text { ing neurocysticercosis (tapeworm infection of the brain)' (Salinas } \\
1999), \text { which was withdrawn from The Cochrane Library in 2005 } \\
\text { due to the availability of new trial evidence. }\end{array}$ \\
$\begin{array}{l}\text { A new team of authors worked on this review. The criteria for in- } \\
\text { clusion of trials has changed. }\end{array}$ \\
\hline
\end{tabular}

\section{H I S T O R Y}

Protocol first published: Issue 4, 2006

Review first published: Issue 2, 1996

\begin{tabular}{lll}
\hline Date & Event & Description \\
\hline 5 May 2009 & New search has been performed & $\begin{array}{l}\text { Search updated; see 'Search methods for identification of stud- } \\
\text { ies'. }\end{array}$ \\
\hline
\end{tabular}

\section{CONTRIBUTIONSOF AUTHORS}

The selection of trials for inclusion, assessment of methodological quality, and data extraction was undertaken as indicated in the methods of the review. The analyses were undertaken mainly by Katharine Abba, in consultation with the other two authors. All three authors contributed to the discussion and conclusions of the review. 


\section{DECLARATIONS OF INTEREST}

None known.

\section{SOURCES OF SUPPORT}

\section{Internal sources}

- Liverpool School of Tropical Medicine, UK.

- Apollo Hospital, Chennai, India.

\section{External sources}

- Department for International Development, UK.

\section{DIFFERENCES BETWEEN PROTOCOL AND REVIEW}

An additional outcome was added: 'resolution of symptoms' as this was an important outcome presented in reports of some of the included trials. An additional category was also added as a control group intervention in the inclusion criteria: 'another dose or duration of anthelmintic', as it became apparent that these comparisons would be important.

\section{N DEX TERMS}

\section{Medical Subject Headings (MeSH)}

Adrenal Cortex Hormones [therapeutic use]; Albendazole [therapeutic use]; Anticestodal Agents [ ${ }^{\star}$ therapeutic use]; Brain Diseases [ ${ }^{\star}$ drug therapy] [parasitology]; Neurocysticercosis [ ${ }^{\star}$ drug therapy]; Praziquantel [therapeutic use]; Randomized Controlled Trials as Topic; Trichlorfon [therapeutic use]

\section{MeSH check words}

Adult; Child; Humans 